\title{
Służby audytorskie lądowych sił zbrojnych w systemie rosyjskiego sądownictwa wojskowego w XVIII i pierwszej połowie XIX w.
}

Następstwem przeprowadzonej przez Piotra I reformy wojskowej stało się utworzenie w Rosji pochodzącej z poboru armii regularnej. Pojawienie się nowoczesnych sił zbrojnych pociągnęło za sobą konieczność przeprowadzenia zmian na płaszczyźnie sądownictwa wojskowego. Proces ten trwał do chwili opublikowania w 1716 r. Regulaminu Wojskowego, który to dokument legł u podstaw organizacji systemu wymiaru sprawiedliwości w armii carskiej na wiele dziesięcioleci. Jego składową częścią stały się służby audytorskie. Celem publikacji jest przybliżenie polskiemu czytelnikowi całościowej organizacji oraz zasad funkcjonowania instytucji audytoriatu do 1867 r., kiedy na fali przeprowadzonej wówczas reformy sądownictwa wojskowego nastąpiła jej ostateczna likwidacja. W celu lepszego zrozumienia natury i specyfiki instytucji, o której mowa, zabiegiem koniecznym staje się charakterystyka ustroju sądownictwa wojskowego carskiej Rosji w przedziale czasowym, jaki został określony w tytule.

\section{STRUKTURA WYMIARU SPRAWIEDLIWOŚCI \\ ROSYJSKICH SIŁ ZBROJNYCH W XVIII I PIERWSZEJ POŁOWIE XIX W.}

\subsection{Podstawy prawne rosyjskiego sądownictwa wojskowego}

Model sądownictwa armii carskiej sprzed 1867 r. powstawał stopniowo, przez kilkanaście dziesięcioleci, a jego trwałe fundamenty położył Piotr I. Dzięki zabiegom tego władcy ukazał się pokaźny materiał ustawodawczy określający mechanizmy działalności organów i urzędników, ponoszących odpowiedzialność 
za wykonywanie sądownictwa w lądowych siłach zbrojnych. Proces stanowienia prawodawstwa wojskowego $\mathrm{w}$ dobie panowania pierwszego rosyjskiego imperatora można podzielić na dwa etapy. W pierwszym, trwającym od końca lat 90. XVII w. do pierwszych lat XVIII w., ukazało się wiele regulacji (artykuły, punkty, instrukcje i ukazy) o wąskim zakresie merytorycznym oraz dwa obszerniejsze regulaminy karne: w 1702 r. Kodeks lub prawo postępowania generatów, średnich i mniejszych rang $i$ szeregowych żotnierzy (bardziej znany jako Utożenie Szeremietjewa) oraz w 1706 Krótki Artykut Aleksandra Mienszykowa. Dodatkowo światło dzienne ujrzały wówczas: Regulamin Wejde (inaczej: Nakaz Wojskowy lub Artykuly Wojskowe) z 1698 r. i Regulamin minionych lat, datowany na okres 1700-1705. Wszystkie one posiadały cechy właściwe ustawom karnym i procesowym, jak również regulaminom dyscyplinarnym oraz przepisom z dziedziny służby wewnętrznej i wartowniczej. Rola tych dokumentów w procesie rozwoju rosyjskiego prawodawstwa wojskowego sprowadzała się do tego, że po raz pierwszy dokonano w nich reglamentacji organów wymiaru sprawiedliwości oraz procedur sądowych. Utożenie Szeremietjewa i Krótki Artykut przygotowano na niskim poziomie techniki prawnej, w oparciu o źródła zachodnioeuropejskie, choć bez wątpienia z wykorzystaniem własnych doświadczeń wyniesionych tak z Wojny Północnej, jak i podróży zagranicznych samego Piotra I oraz - reprezentujących różne dziedziny - specjalistów. Ponieważ pierwszy z wymienionych aktów opublikowano z myślą o jednostkach walczących w Inflantach, zaś drugi odnosił się jedynie do formacji dragonów, oba były ustawami tymczasowymi, o ograniczonym stopniu oddziaływania ${ }^{1}$. Zapewne dlatego - według D. Sierowa - nie weszły one do Petnego Zbioru Praw Imperium Rosyjskiego, podobnie zresztą jak Regulamin Wejde i Regulamin minionych lat ${ }^{2}$.

$\mathrm{W}$ drugiej fazie kształtowania się prawa wojskowego, zamykającej się w przedziale pierwsze dziesięciolecie - pierwsza połowa lat 20. XVIII w., pojawiła się duża ilość regulacji sporządzonych z większą dbałością o stronę techniczną i w przeważającej mierze skoordynowanych ze sobą pod względem treści. Materiał ten różnicował się już na ustawy natury: prawno-procesowej, proceduralnej i administracyjnej. Ze względu na osobiste zaangażowanie Piotra I, wszystkie

${ }^{1}$ D.O. Sierow, Wojenno-ugołownoje i wojenno-prociessual'noje zakonodatiel'stwo Rossii pierwoj czetwierti XVIII w. (opyt sistiematiczeskogo obozrienija), „Aktualnuje problemy rossijskogo prawa" 2014, nr 2, s. 166. Za wzorzec dla Kodeksu Szeremietiewa posłużyły artykuły wojskowe króla Danii Chrystiana V, a Krótki Artykuł oparto na jurystycznych rozwiązaniach niemieckich; zob. M.W. Liwenson, Pojedinok w zakonodatiel'stwie i naukie, Sankt-Pietierburg 1900, s. 19; A.Z. Myszłajewskij, Piotr Wielikij. Wojennyje zakony i instrukcji (izdannyje do 1715 g.), Sankt-Pietierburg 1894, s. XXIX, XXXVI.

2 Zdaniem innych autorów Ułożenije Szeremietjewa zostało sporządzone na podstawie dekretu carskiego, czyli musiało posiadać moc prawną; zob. W. Martynow, Razwitije wojenno-disciplinarnogo zakonodatiel'stwa w pieriod prawlienija Pietra I, „Włast” 2012, nr 12, s. 164. 
sporządzone wówczas dokumenty zostały ogłoszone drukiem, co automatycznie nadawało im moc prawną na obszarze całego państwa. Największe znaczenie dla sądownictwa lądowych sił zbrojnych zyskały trzy pokaźne dokumenty. Dwudziestego szóstego kwietnia 1715 r. ukazały się Artykuł Wojskowy z krótkim komentarzem, stanowiący wojskowy kodeks karny, oraz Krótkie ujęcie procesów lub spraw sądowych, poświęcone prawie w całości kwestiom organizacji wymiaru sprawiedliwości i procedurom sądowym. Pierwsze redakcje tych ustaw pochodziły z lat 1712-1714³. Artykuł Wojskowy i Krótkie ujęcie procesów... weszły, jako części druga i trzecia, do wydanego 30 marca 1716 r. Regulaminu Wojskowego, który systematyzował i uzupełniał dotychczasowe ustawodawstwo odnoszące się - oprócz sądownictwa - do zasad kompletowania, organizacji, szkolenia i kształcenia wojsk. Dokument ten, podobnie jak Artykut Wojskowy i Krótkie ujęcie procesów..., był w istocie kompilacją obcych źródeł jurystycznych, w pierwszej kolejności szwedzkich artykułów wojskowych, uzupełnionych elementami zapożyczonymi z niemieckich, holenderskich, francuskich i duńskich rozwiązań prawnych, jak i rodzimych doświadczeń, zdobytych w toku wcześniejszych prac legislacyjnych ${ }^{4}$.

Znaczenie Artykutu Wojskowego i Krótkiego ujęcia procesów... okazało się tak znaczące, że armia korzystała z nich do lat 30. XIX w. W 1839 r. władze wydały drukiem, jako piątą część Zbioru uchwal wojskowych, Regulamin wojskowo-karny ${ }^{5}$. W odniesieniu do okresu wojny oparto go na Regulaminie sadownictwa polowego i Polowym kodeksie karnym, opublikowanych 27 stycznia 1812 r. w ramach tzw. Zarzadzeń w zakresie dowodzenia Wielka Armia Czynna ${ }^{6}$. Ustawodaw-

${ }^{3}$ D.O. Sierow, Wojenno-ugołownoje..., s. 168. Wszystkie daty dzienne w tekście zostały podane w starym stylu.

${ }^{4}$ W. Martynow, op. cit., s. 165. W pracach nad Artykutem Wojskowym Rosjanie sięgnęli przede wszystkim do szwedzkiego Artykułu Wojskowego z 1683 r., jak również - pochodzących z XVI-XVII w. - duńskich, cesarsko-rzymskich (austriackich), a nawet bizantyjskich norm prawodawstwa wojskowego i karnego. Główną podstawę Krótkiego ujęcie procesów... stanowiły z kolei austriackie i saksońskie akta wojskowo-procesowe; zob. D.O. Sierow, Zabytyie riedakcii Artikuła woinskogo $i$,Kratkogo izobrażenija processow ili sudiebnych tjażb (iz istorii kodifikacii wojennogo zakonodatiel'stwa Rossii XVIII w.), „Lex russica” 2013, nr 2, s. 113-121.

${ }^{5} \mathrm{~W}$ manifeście z 25 czerwca 1839 r. O wydaniu Zbioru ustaw wojskowych zaznaczono, że wydawnictwo to, zyskujące moc prawną od 1 stycznia 1840 r., nie wprowadziło żadnych modyfikacji do obowiązujących w lądowych siłach zbrojnych ustaw, a jego nadrzędnym celem było jedynie uporządkowanie i ujednolicenie systemu prawodawczego. Wszelkiego rodzaju zmiany i uzupełnienia należało edytować w corocznych kontynuacjach rzeczonego kodeksu. Niemniej jednak z powodu dużej ilości nowych regulacji zaistniała potrzeba wznowień Zbioru ustaw wojskowych. W sumie w pierwszej połowie XIX w. ukazały się dwie redakcje, pochodzące z lat 1838 i 1859; zob. Potnoje Sobranije Zakonow Rossijskoj Impierii (dalej: PSZRI) (II), t. 14, otd.1, nr 12468, s. 578; t. 35, otd. 2, nr 36464, s. 525-526.

${ }^{6} \operatorname{PSZRI}(\mathrm{I}), \mathrm{t} .32$, nr 24975, s. 43-164. 
ca, wzorując się na regulacjach francuskich z czasów rewolucji oraz I Cesarstwa, dokonywał w nich kodyfikacji i typizacji przestępstw popełnianych w toku działań wojennych ${ }^{7}$. Z kolei w czasie pokoju aparat sprawiedliwości miał korzystać z przepisów recypowanych z Artykutu Wojskowego z 1715 r. Reasumując, Regulamin wojskowo-karny z 1839 r. stanowił syntezę norm zawartych w sądowych kodeksach wojskowych publikowanych w różnych latach i okolicznościach. Stąd brały się sprzeczności i różnice widoczne choćby w przedmiocie karalności tych samych przestępstw w warunkach wojennych i pokojowych. Paradoksalnie, sankcje karne podczas konfliktu zbrojnego okazywały się łagodniejsze od stosowanych w okresie pokoju. Na fali dążeń do usunięcia tego rodzaju niedogodności zdecydowano się przeprowadzić kodyfikację armijnych regulacji karno-procesowych, czego wynikiem był właśnie Regulamin wojskowo-karny ${ }^{8}$. Jego reedycje z lat 1855 i 1859 wiązały się już z koniecznością skoordynowania działalności i procedur wojskowych organów wymiaru sprawiedliwości z karnym ustawodawstwem powszechnym. Jak wiadomo, pomiędzy 1830 r. a 1835 r. ukazała się pierwsza seria Petnego Zbioru Praw Imperium Rosyjskiego, jak również Zbiór Praw Imperium Rosyjskiego, którego tom XV (Zbiór ustaw karnych) zawierał przepisy z dziedziny ustawodawstwa karnego ${ }^{9}$. Natomiast w 1845 r. światło dzienne ujrzał Kodeks kar głównych i poprawczych, nowelizowany w 1857 i 1866. Niezależnie od zabiegów służących usystematyzowaniu, a przez to unowocześnieniu organizacji i systemu orzecznictwa sądów wojskowych, nadal w mniejszym lub większym stopniu organy władzy sądowniczej korzystały z rozwiązań przyjętych przez Piotra I w Regulaminie Wojskowym, którego działaniem - w oparciu o ukaz z 10 kwietnia 1716 r. - objęto całą ludność Cesarstwa Rosyjskiego ${ }^{10}$. Zatem do chwili wydania w 1835 r. Zbioru Praw Imperium Rosyjskiego orzecznictwo w są-

7 Stolietije Wojennogo Ministierstwa: Gtawnoje wojenno-sudnoje uprawlienije. Istoriczeskij oczerk (dalej: SWM) pod ried. D.A. Skałona, t. 12, cz. 2, k. 1, Sankt-Pietierburg 1914, s. 113.

${ }^{8}$ P.P. Kamajew, Razwitije otieczestwiennogo ugołownogo zakonodatiel'stwa ob otwietstwiennosti za posjagatiel'stwa na wojennoje imuszczestwo do 1917 g., „Biznies w zakonie” 2013, nr 2, s. $43-44$.

${ }^{9}$ Obszerniej na temat prac kodyfikacyjnych w Rosji w latach 20. i 30. XIX w.: T.M. Bażenowa, S.W. Kodan, Swod zakonow Rossijskoj impierii w diejatiel'nosti Rossijskogo gosudarstwa po uporjadoczeniju zakonodatiel'stwa (wtoraja czetwiert'XIX - naczato XX wieka) [w:] Sistiematizacija zakonodatiel'stwa $w$ Rossii (istoriko-prawowyie, tieorietiko-mietodołogiczeskije i tiechniko-juridiczeskoije probliemy). K 175-lietiju Swoda zakonow Rossijskoj impierii, Moskwa-Niżnij Nowgorod-Jekatierinburg 2008, s. 23-42.

${ }^{10}$ PSZRI (I), t. 5, nr 3010, s. 457. Niezależnie od jednoczesnego posługiwania się Artykułem Wojskowym przez sądy powszechne i wojskowe, nadal te pierwsze stosowały niektóre normy przestarzałego już w XVIII w. Ułożenia Soborowego z 1649 r. Dwoistość ta nie zaniknęła po wydaniu w latach 1835-1839 Zbioru ustaw karnych i Regulaminu wojskowo-karnego. Zatem przenikanie się dwóch dziedzin wymiaru sprawiedliwości: powszechnego i wojskowego stanowiło stały rys prawodawstwa rosyjskiego do 1867 r.; zob. SWM, t. 12, cz. 2, k. 1, s. 185. 
dach powszechnych opierało się na osiągnięciach legislacji opracowanej z myślą o siłach zbrojnych, co jaskrawo odbiegało od ówczesnych standardów europejskich. Ogólnie rzecz ujmując, armijny aparat sprawiedliwości, jaki wykształcił się w ciągu pierwszej ćwierci XVIII w., przetrwał w zasadzie bez większych transformacji do $1867 \mathrm{r}$.

\subsection{Sądy wojskowe}

Nowe instytucje sądownicze pojawiły się w armii carskiej na początku XVIII w. Nazywano je kriegsrechtami. Po raz pierwszy zasady ich funkcjonowania zostały szerzej sprecyzowane w Regulaminie minionych lat oraz Krótkim Artykule ${ }^{11}$. Zgodnie z literą tych ustaw kriegsrechty, dzielące się na pułkowe i generalne, stanowiły ciała kolegialne powoływane doraźnie na wniosek dowódców pułków z grona oficerów liniowych, w celu rozpatrywania spraw karnych z udziałem oficerów pełniący służbę w tej samej jednostce, co członkowie sądu. W skład kriegsrechtów wchodzili: przewodniczący (nazywany również prezesem lub prezydentem), sędziowie (asesorowie) oraz audytor. Stosownie do istoty sprawy każdy sędzia wypowiadał sentencję z propozycją kary dla oskarżonego. Ostateczny werdykt kierowano następnie do zatwierdzenia - w trybie obowiązkowym - do dowódcy jednostki wojskowej; jeśli kierował on pracami składu orzekającego, to wyrok trafiał do innego naczelnika wojskowego wyższego szczebla. Krótki Arty$k u t$, w przeciwieństwie do Regulaminu minionych lat, nie przewidywał możliwości złożenia apelacji od wyroku kriegsrechtu pułkowego do sądu wyższej instancji, czyli kriegsrechtu generalnego ${ }^{12}$.

Bardziej szczegółowa reglamentacja mechanizmów funkcjonowania i uprawnień kriegsrechtów nastąpiła wraz z publikacją Krótkiego ujęcia procesów..., a potem Regulaminu Wojskowego ${ }^{13}$. W przeciwieństwie do wcześniejszych regulacji, w tych aktach znalazły się również normy odnoszące się do sytuacji procesowej: audytora, podsądnego i świadków, jak również kwestii wiążących się z zasadami organizacji i prowadzenia rozpraw, wydawania wyroków i nabierania przez nie mocy prawnej. Podstawą wymiaru sprawiedliwości armii lądowej stały się kriegsrechty. Ustawodawca utrzymał ich podział na generalne i pułkowe, czyli wyższe i niższe. Niemniej stosownie do rozdziału 50. Regulaminu Wojskowego

${ }^{11}$ Ustaw Prieżnich Liet [w:] A.Z. Myszłajewskij, op.cit., s. 4-10; Artikuł Kratkij [w:] A.Z. Myszłajewskij, op, cit., s. 70-72, 73-74.

${ }^{12}$ Ibidem. O sądach wojskowych, jako kolegialnych składach orzekających, wzmiankowano po raz pierwszy w Ułożeniu Szeremietjewa, choć bez podania bliższych informacji o ich strukturze i uprawnieniach; zob. Ułożenije ili prawo woinskogo powiedienija [w:] M.P. Roziengiejm, Oczierk wojenno-sudnych uczrieżdienij w Rossii do komcziny Pietra Wielikogo, Sankt-Pietierburg 1878, priłożenije VI, s. 269-294.

${ }^{13}$ PSZRI (I), t. 5, nr 3006, s. 235-236, 265-267, 382-388. 
obie odmiany wspomnianych sądów uznano za instytucje wyższej instancji, a więc posiadające uprawnienia do wydawania ostatecznych werdyktów. Kriegsrechtom generalnym w pierwszej instancji podlegały: przestępstwa państwowe, niezgodne z prawem czyny, jakich dopuściły się całe jednostki i pododdziały, jak również sprawy karne i cywilne z udziałem wyższych oficerów, czyli generałów i sztabsoficerów. Wszystkie pozostałe wypadki złamania prawa, w których stroną byli niżsi oficerowie (oberoficerowie) oraz podoficerowie i szeregowcy (niższe rangi), powinny trafiać przed oblicze kriegsrechtów pułkowych. Oprócz tego uprawnienia wojskowych organów orzekających obejmowały sprawy natury karnej i cywilnej z udziałem przebywających przy oddziałach cywilów ${ }^{14}$. Wprawdzie Krótkie ujęcie procesów... dopuszczało możliwość wszczynania postepowań apelacyjnych przed sądami generalnymi w stosunku do orzeczeń ferowanych przez kriegsrechty pułkowe, ale - jak zaznaczył D. Sierow - w osiemnastowiecznej rosyjskiej praktyce sądowej nigdy nie uciekano się do tej normy, podobnie zresztą jak i w pierwszej połowie następnego stulecia ${ }^{15}$. Innymi słowy, pomiędzy sądami pułkowymi i generalnymi nie istniała ani spójność organizacyjna, ani hierarchia instancyjna, co oznaczało, że działały one w oderwaniu od siebie. Kriegsrechty generalne różniły się od swych odpowiedników powoływanych na szczeblu pułków tylko statusem formalno-prawnym, wyrażającym się w zakresie kompetencji określonych w zależności od charakteru rozpatrywanej sprawy oraz pozycji służbowej podsądnego. Martwą literą pozostawał także zapis Krótkiego ujęcia procesów... o dopuszczalności powództwa cywilnego przed sądami wojskowymi, w związku z czym przepisy reglamentujące udział w rozprawach adwokatów i pełnomocników nie zyskały praktycznego zastosowania w czasie rozpraw ${ }^{16}$. Zatem działalność kriegsrechtów ograniczała się stricte do wojskowych i sił zbrojnych.

Oprócz prezesa (nazwa ta przyjęła się ostatecznie w odniesieniu do przewodniczących) i asesorów, przy kriegsrechtach znajdował się personel pomocniczo-techniczny reprezentowany przez sekretarza sporządzającego protokoły oraz pełniącego obowiązki prystawa sądowego - adiutanta. Zgodnie z wolą legislatora sądy wojskowe powinny grupować osoby cieszące się zaufaniem państwa i społeczeństwa. Kriegsrechty należało powoływać w liczbie 13 ludzi. Praktycznie dopuszczano jednak możliwość prowadzenia procesów w składzie zredukowanym do 7 osób, gdyby nie udało się znaleźć odpowiednich oficerów w liczbie wymaganej przez ustawę. Sądom generalnym przewodniczyli generałowie feldmarszałkowie lub generałowie, zaś pułkowym - pułkownicy albo podpułkownicy, czy

14 Ibidem, s. 265-267.

15 Ibidem, s. 408-409; D.O. Sierow, Sudoustrojstwo i sudoproizwodstwo w Rossii nakanunije sudiebnoj rieformy Pietra: tiendiencii razwitija (1696-1716 gg.) [w:] Probliemy istorii Rossii, wyp. 7: Istoczniki i jego intierprietacii, Jekatierinburg 2008, s. 124.

${ }^{16}$ PSZRI (I), t. 5, nr 3006, s. 391-392. 
- w razie konieczności - majorzy. Na stanowiska 6 asesorów w kriegsrechtach generalnych należało powołać: 2 generałów poruczników, 2 generałów majorów i 2 brygadierów lub pułkowników. W razie braku generałów sędziami mogli zostać sztabs-oficerowie. Z kolei wśród 6 asesorów sądu pułkowego powinno się znaleźć: 2 kapitanów, 2 poruczników oraz 2 chorążych. Jeśli sądy obradowały w liczbie 12 asesorów, to skład orzekający musiał zostać uzupełniony przez: 2 sierżantów, 2 kaprali i 2 szeregowych, co oznaczało dopuszczenie do orzecznictwa przedstawicieli niższych rang ${ }^{17}$.

Niezależnie od kriegsrechtów, stosownie do litery Regulaminu Wojskowego oraz - opublikowanej 15 lutego 1723 r. w odpowiedzi na raport Kolegium Wojny - rezolucji cesarskiej, działał w Moskwie stały niższy sąd garnizonowy, notabene istniejący do dnia dzisiejszego ${ }^{18}$. Zajmował się on przeważnie rozpatrywaniem spraw oficerów i żołnierzy uchylających się od służby wojskowej, których zatrzymano w Moskwie i jej najbliższych okolicach. Funkcję prezesa tego organu pełnił członek Kolegium Wojny w randze brygadiera, a towarzyszyło mu 2 asesorów w stopniu pułkownika oraz oberaudytor. W sumie - powołując się na opinię N. Pietuchowa - pod względem swego składu sąd moskiewski, posiadając specjalny status prawny, nieco przypominał kriegsrecht generalny, chociaż o zmniejszonej liczbie asesorów ${ }^{19}$. Analogicznymi kompetencjami prawodawca obdarzył utworzony 9 lutego 1777 r. w Sankt Petersburgu stały sąd wojskowy, nazwany kriegsrechtem. Zasiadali w nim naczelnik garnizonu stołecznego oraz asesorowie, wyznaczani według kolejności z pułków garnizonowych ${ }^{20}$.

Szczególne miejsce w strukturze wojskowego wymiaru sprawiedliwości zajmował tzw. skororieszytiel'nyj sud. Miał on być powoływany tylko w czasie kampanii wojennych oraz podczas oblegania twierdz przez nieprzyjaciela. Informacje na temat procedur określających mechanizmy jego funkcjonowania, zawarte już w Krótkim Artykule, a potem Regulaminie Wojskowym, są jednak bardzo skąpe i niejasne ${ }^{21}$. Dopiero Zarządzenia w zakresie dowodzenia Wielka Armia Czynna ze stycznia 1812 r., przewidujące możliwość powoływania podczas wojny audytoriatów i sądów polowych, wprowadzały jasne przepisy dotyczące ustroju oraz zasad orzecznictwa w sądach ferujących wyroki w warunkach konfliktu militar-

${ }^{17}$ Ibidem, s. 265, 384.

${ }_{18}$ PSZRI (I), t. 5, nr 3006, s. 265; t. 7, nr 4166, s. 24.

19 N.A. Pietuchow, Istorija wojennych sudow Rossii, Moskwa 2003, s, 40.

${ }^{20}$ PSZRI (I), t. 20, nr 14 577, s. 497-498. Autorzy Stolietija Wojennogo Ministierstwa, a za nimi N. Pietuchow - który notabene w wielu miejscach swej monografii często dosłownie przytacza wyjątki z tej pracy, nie podając o tym (poza kilkoma wyjątkami) informacji w odsyłaczach - błędnie podali, że kriegsrecht petersburski utworzono w 1771 r; zob. SWM, t. 12, cz. 1, k. 1, Sankt-Pietierburg 1902, s. 139; N. A. Pietuchow, op.cit., s. 53.

${ }^{21}$ Artikut Kratkij ..., s. 26; PSZRI (I), t. 5, nr 3006, s. 266-267. 
nego. Według tej regulacji sprawy miały być rozpatrywane w dwóch instancjach. Wyższą stanowił trzyosobowy Audytoriat Polowy, podlegający bezpośrednio głównodowodzącemu armią (względnie samodzielnym korpusem), zaś niższą tworzone przez Audytoriat Polowy sądy wojskowe ${ }^{22}$.

Specyficznym rodzajem armijnych organów wymiaru sprawiedliwości były tzw. sądy społeczności oficerskiej (inaczej: sądy honorowe). Fundamenty dla ich działalności na szczeblu pułków położono w latach 1714-1721. W wydanych wtedy dokumentach nie zostały jednak sprecyzowane obowiązujące w nich procedury oraz wachlarz środków karnych, jakim mogły one dysponować. Następne lata przyniosły kilka ustaw koncentrujących się wokół tych instytucji, ale wszystkie one miały jedynie charakter norm tymczasowych ${ }^{23}$. Dopiero Regulamin o zachowaniu dyscypliny wojskowej i o karach dyscyplinarnych z 6 lipca 1863 r. szczegółowo zdefiniował zasady organizacji i zakres prerogatyw sądów oficerskich. Uzyskały one prawo do usuwania oficerów nie tylko z zajmowanych stanowisk, ale w ogóle z armii, za popełnienie czynu niezgodnego z kodeksem honorowym. Chociaż rzeczone organy wymiaru sprawiedliwości grupowały wszystkich pełniących służbę w pułkach, samodzielnych batalionach i brygadach artylerii oficerów, to kluczowe znaczenie w ich pracy zajmowały, składające się z trzech do pięciu oficerów, rady rozjemców ${ }^{24}$.

Pojawienie się na początku XVIII w. kriegsrechtów nie doprowadziło do utraty uprawnień sądowniczych przez niektóre centralne instytucje resortowe odpowiedzialne za funkcjonowanie sił zbrojnych. Do lat 1716-1717 prawo do wyrokowania o winie i niewinności oficerów i żołnierzy sił lądowych posiadały Prikazy: razrjadnyj, artyleryjski, cudzoziemski, rajtarski, aptekarski oraz kancelaria wojskowa. Urzędy te pracowały w całkowitym oderwaniu od systemu kriegsrechtów generalnych i pułkowych. $\mathrm{Z}$ tego powodu przez pewien okres czasu w państwie carów funkcjonował mieszany system armijnego wymiaru sprawiedliwości, co musiało powodować chaos i utrudnienia w procesie orzecznictwa ${ }^{25}$.

\subsection{Uprawnienia sądowe centralnych organów zarządu wojskowego}

Kolegium Wojny jako instytucja zarządu siłami zbrojnymi na szczeblu centralnym zostało utworzone na bazie kancelarii wojskowej w 1717 r., choć ukaz $\mathrm{w}$ tej sprawie opublikowano dopiero 12 grudnia następnego roku ${ }^{26}$. Stało się ono

\footnotetext{
22 PSZRI (I), t. 32, nr 24975, s. 75-80.

${ }_{23} S W M$, t. 12, cz. 1, k. 1, s. 123-124; P.A. Szwiejkowskij, Sud obszczestwa oficerow i duel' $w$ wojskach rossijskoj armii, Sankt-Pietierburg 1898, s. 4-7.

${ }^{24}$ PSZRI (II), t. 38, otd. 1, nr 39830, s. 781-784.

25 D.O. Sierow, Sudoustrojstwo..., s. 124.

${ }^{26} \operatorname{PSZRI}(\mathrm{I})$, t. 5, nr 3255, s. 601.
} 
wyższym organem sądowym w stosunku do całej armii lądowej, jak również przez pewien czas do marynarki wojennej. Otóż zgodnie z dekretem z 3 marca 1719 r. zatwierdzone (konfirmowane) przez dowódców korpusów wyroki kriegsrechtów pułkowych i generalnych wydane w sprawach podoficerów i szeregowców, w których została zasądzona kara śmierci, należało kierować do Kolegium Wojny, w celu ich konfirmacji ${ }^{27}$. Po upływie dwóch lat, 24 lipca 1721 r., opublikowano ukaz poświęcony poprawie warunków pracy sądów wojskowych. Od tego momentu ostatecznemu zatwierdzeniu przez Kolegium Wojny podlegały wszystkie bez wyjątku sentencje końcowe zasądzone przez kriegsrechty i konfirmowane następnie przez dowodzących korpusami. Nowością była norma o nadsyłaniu do Kolegium Wojny wraz z wyrokiem sądowym już nie oryginału akt sprawy, ale potwierdzonego przez audytorów wyciągu ${ }^{28}$. Dążąc do usprawnienia pracy sądów i - jak sugeruje N. Pietuchow - przyspieszenia orzecznictwa, prerogatywy sądowe Kolegium Wojny uległy poszerzeniu 11 listopada 1724 r. W opublikowanym tego dnia dekrecie ustawodawca polecił kriegsrechtom kierować do wspomnianego organu wyłącznie wyroki sądowe dotyczące oficerów ${ }^{29}$. Tym razem Kolegium Wojny uzyskało prawo do zatwierdzania sentencji, jakie zapadły tylko i wyłącznie w stosunku do oberoficerów. W sumie, na płaszczyźnie wymiaru sprawiedliwości rzeczone kolegium przeprowadzało rewizję spraw rozpatrywanych przez kriegsrechty, posiadając równocześnie uprawnienia do ostatecznego konfirmowania sentencji końcowych wydanych w odniesieniu do - określonych w poszczególnych ustawach - posiadaczy stopni wojskowych. Zatem instytucja, o której mowa, pełniła rolę wyższego sądu rewizyjnego, początkowo tylko w odniesieniu do werdyktów zasądzonych przez kriegsrechty, a po śmierci Piotra I także wyroków wydanych przez powszechne organy orzekające, które rozpatrywały sprawy z udziałem wojskowych. Do tego dochodził obowiązek prowadzenia sprawozdawczości w stosunku do całego pionu sądowniczego lądowych sił zbrojnych $^{30}$. Zakres kompetencji sądowniczych Kolegium Wojny zmienił się dopiero po utworzeniu w 1797 r. - funkcjonującego w jego ramach na prawach specjalnej instytucji - Audytoriatu Generalnego oraz powołaniu do życia w 1802 r. Ministerstwa Sił Wojskowo-Lądowych, którego częścią składową stał się departament audytorski ${ }^{31}$.

W czasach panowania Piotra I przy Kolegium Wojny zainstalowano urząd prokuratora. Zaniknął on, co prawda, wkrótce po śmierci cara - reformatora, ale

${ }^{27}$ PSZRI (I), t. 5, nr 3315, s. 670.

${ }^{28}$ PSZRI (I), t. 6, nr 3807, s. 410-411.

${ }^{29}$ PSZRI (I), t. 7, nr 3589, s. 361.

${ }^{30} S W M$, t. 12, cz. 1, k. 1, s. 140.

${ }^{31}$ D.I. Raskin (red.), Wysszije i central'nyje gosudarstwiennyje uczrieżdienija Rossii 1801-1917, t. 4, Sankt-Pietierburg 2004, s. 35, 39. 
został przywrócony przez Annę Iwanownę. Stosownie do ukazów z kwietnia (brak daty dziennej) 1792 r. i 26 stycznia 1794 r. prokurator wojskowy mógł domagać się od prokuratora generalnego wydania rozporządzenia polecającego formacjom armijnym dostarczenia mu informacji o liczbie oficerów i żołnierzy skazanych przez kriegsrechty ${ }^{32}$.

\subsection{Kompetencje sądowe Senatu Rządzącego i cara}

Powołany do istnienia 22 lutego 1711 r. Senat Rządzący, w ukazie z 2 marca tego roku otrzymał uprawnienia w przedmiocie wymierzania sprawiedliwości. Stosownie do pierwotnego zamiaru ustawodawcy, na mocy powyższego aktu stał się on z jednej strony sądem pierwszej instancji, władnym rozstrzygać sprawy, jakie wpłynęły z oskarżenia niesprawiedliwych sędziów i donosicieli, natomiast $\mathrm{z}$ drugiej - instancją apelacyjną w sprawach rozstrzygniętych przez niższe sądy w sposób niezgodny z prawem. Prerogatywy te dotyczyły wszystkich działających w państwie organów sądowych tak powszechnych, jak i specjalnych. Do tej kategorii odnosiły się między innymi sądy wojskowe. Przez jakiś czas, być może do chwili ukonstytuowania się Kolegium Wojny, w ramach Senatu funkcjonował wydział (referat) razrjadnyj. Przejął on kompetencje po zlikwidowanym Prikazie Razrjadnym, a w orbicie jego kompetencji znalazło się wykonywanie sądownictwa w stosunku do pułkowników, niektórych innych wojskowych i poddjaczych ${ }^{33}$. Siódmego czerwca 1728 r. został opublikowany ukaz, który nakazywał zaprzestać przekazywania Senatowi spraw kryminalnych z udziałem wojskowych, ograniczając ich rozpatrywanie i konfirmowanie zasądzonych w nich werdyktów do Kolegium Wojny ${ }^{34}$. Zatem Senat przez pewien czas uczestniczył tak samo jak cesarz, Kolegium Wojny i wyżsi dowódcy armijni w procesie orzecznictwa wojskowego, chociaż we wspomnianym powyżej dekrecie z 11 listopada 1724 r. nie było o tym mowy. Ogólnie rzecz ujmując, złożony z kilku departamentów Senat - jako stróż praworządności w całym Imperium Rosyjskim - na płaszczyźnie sądownictwa wojskowego pełnił rolę wyższej instancji apelacyjnej od, niezgodnych z prawem wyroków, jakie zapadły w Kolegium Wojny. W latach 1763-1898 prerogatywy w tym zakresie koncentrowały się w trzeciej (a od 1805 r. w pierwszej) ekspedycji czwartego departamentu do spraw cywilnych. Poza tym Senat rozstrzygał kwestie podsądności spraw, które wynikały z niejasności ustaw określających kompetencje poszczególnych sądów, jak również zagadnienia wiążące się z przenoszeniem spraw z jednego organu orzekającego do drugiego. Podejmował o także decyzje

${ }^{32}$ PSZRI (I), t. 23, nr 17040, s. 324-325; nr 17176, s. 483-484.

33 PSZRI (I), t. 4, nr 2328, s. 642-643.

${ }^{34}$ PSZRI (I), t. 8, nr 5279, s. 46. Stolietija Wojennogo Ministierstwa podało niewłaściwą datę wydania tego ukazu -7 czerwca 1722 r; zob. $S W M$, t. 12, cz. 1, k. 1, s. 148. 
o pozostawieniu czy też przeniesieniu konkretnej sprawy do właściwej jej charakterowi instytucji wymiaru sprawiedliwości ${ }^{35}$.

Senat raczej nie odgrywał dużej roli w orzecznictwie wojskowym, ograniczając się do kontroli działalności Kolegium Wojny pod kątem przestrzegania przez nie procedur sądowych. Pośrednio świadczy o tym zapis w dekrecie z 19 kwietnia 1778 r. zakazujący funkcjonującemu przy Senacie Kolegium Rewizyjnemu ingerować w sprawy podlegające kompetencyjnie sądom wojskowym, nawet gdyby dotykały interesów skarbowych państwa ${ }^{36}$. Wszystkie tego typu przypadki ustawodawca polecał odsyłać do Kolegium Wojny (które tym samym umacniało swą pozycję) jako wyższego organu wymiaru sprawiedliwości w armii.

Ostatnią instancją sądową dla wszystkich rodzajów sądów stanowił car (cesarz). O jego kompetencjach jako najwyższego sędziego i prawodawcy wspominało już Utożenie Soborowe z $1649 \mathrm{r}^{37}$. W praktyce jednak od czasów Piotra I działania kolejnych imperatorów na polu sądownictwa wojskowego ograniczały się do zatwierdzania, a więc nadawania mocy prawnej wyrokom kriegsrechtów, jakie zasądzono na podstawie ukazów z lat 1719-1724 w sprawach oficerów, najpierw wszystkich, a później tylko wyższych (generałów i sztabsoficerów) ${ }^{38}$. Identycznie rzecz się miała po utworzeniu Audytoriatu Generalnego, z tym tylko uzupełnieniem, że car uzyskał wówczas status ostatecznej instancji również w sprawach podoficerów i szeregowców wywodzących się ze szlachty. Monarcha rosyjski zachował więc dla siebie prawo do ewentualnego ułaskawiania lub łagodzenia kar, jakie kriegsrechty lub Kolegium Wojny wydały wobec wszystkich szlachetnie urodzonych wojskowych, niezależnie od ich stopni.

\subsection{Prerogatywy sądownicze urzędników wojskowych}

Niezależnie od scharakteryzowanych już instytucji sądowych ustawodawca obdarzył kompetencjami wiążącymi się z wymiarem sprawiedliwości kilku urzędników, przewidzianych do pracy w rosyjskich lądowych siłach zbrojnych. W myśl Regulaminu Wojskowego z 1716 r. do tej kategorii odnosili się, oprócz generała audytora i generała audytora lejtnanta, również generał gewałdiger (określany też jako rumormajster) oraz fiskałowie. Do powinności generała gewałdigera należało pilnowanie porządku w armii. Posiadając do pomocy jednego lub dwu po-

${ }^{35}$ A.N. Filippow, Prawitiel 'stwujuszczij Sienat w carstwowanije Pietra Wielikogo: t. 1, Istorija Prawitiel'stwujuszczego Sienata za dwiesti liet 1711-1911 gg., Sankt-Pietierburg 1911, s. 328-330, 466-468; Wysszije i central'nyje..., t. 1, s. 98-99.

36 PSZRI (I), t. 20, nr 14732, s. 665.

37 Sobornoje Utożenije 1649 goda [w:] Rossijskoje zakonodatiel'stwo X-XX wiekow, t. 3, pod ried. A.G. Man'kowa, Moskwa 1985, s. 102.

${ }^{38}$ PSZRI (I), t. 5, nr 3315, s. 670; t. 6, nr 3807, s. 410-411; t. 7, nr 3589, s. 361. 
ruczników, miał on czuwać nad przestrzeganiem przez żołnierzy dyscypliny tak w czasie przemieszczania się jednostek, jak i w miejscach ich postoju. Podczas marszu przewidywano oddanie do dyspozycji generałowi gewałdigerowi kilku kawalerzystów, którzy - poruszając się na przedzie i tyle kolumny marszowej - obserwowaliby zachowanie żołnierzy ${ }^{39}$. Przypisane generałowi gewałdigierowi obowiązki natury porządkowej prawodawca potwierdził w wydanych w styczniu 1812 r. Zarządzeniach w zakresie dowodzenia Wielka Armia Czynna, nazywając go wprost generałem-policmajstrem ${ }^{40}$.

Służby fiskalne pojawiły się w armii carskiej 31 lipca 1711 r., wchodząc w skład powołanego w tym samym roku kriegs-komisariatu, stanowiącego centralny organ zaopatrywania i finansowania wojsk. Agendy te uzyskały pierwotnie organizację dwuszczeblową: oberfiskał podlegający bezpośrednio generałkriegskomisarzowi oraz fiskałowie pułkowi. Zgodnie z Regulaminem kriegskomisariatu z 10 grudnia 1711 r., uzupełnionym rok później, jak również Regulaminem Wojskowym z 1716 r. uprawnienia fiskałów koncentrowały się wokół wykrywania wszelkiego rodzaju przypadków łamania prawa, przede wszystkim przestępstw wymierzonych w interesy służby wojskowej i system wymiaru sprawiedliwości, do których należały w pierwszej kolejności: łapownictwo, nadużywanie stanowiska, świadome wydanie niezgodnego z prawem wyroku oraz okradanie skarbu państwa ${ }^{41}$. Zgromadzony materiał dowodowy fiskałowie powinni przekazywać tej instancji sądowej, której podlegała osoba podejrzana o dokonanie przestępstwa.

Wedle opinii D. Sierowa, służby fiskalne stały się pierwszą w państwie carów instytucją nadzorującą proces przestrzegania prawa ${ }^{42}$. Aby fiskałowie mogli ustalić, że prawo zostało złamane - stosownie do litery dekretu z 5 marca 1711 r. - legislator obdarzył ich kompetencjami w zakresie wykonywania czynności operacyjno-śledczych ${ }^{43}$. Dodatkowo, w ukazie z 17 marca 1714 r. oraz Regulaminie Wojskowym zobowiązano fiskałów do wyjaśniania okoliczności tzw. cichych spraw, czyli czynów karalnych z udziałem powodów ${ }^{44}$. Zatem, oprócz funkcji czysto nadzorczych, fiskałowie zostali z mocy prawa zobowiązani do inicjowania spraw karnych, zbierania odnoszących się do nich dowodów, jak również występowania w sądach z oskarżeniami w imieniu państwa, przez co przypominali współczesnych prokuratorów. Przypisane im funkcje nie doczekały się jednak rozwinięcia w późniejszym ustawodawstwie. Instytucja fiskałów w armii carskiej nie przetrwała próby czasu. Po raz ostatni wspominała o nich instrukcja

\footnotetext{
39 PSZRI (I), t. 5, nr 3006, s. 250-251.

40 PSZRI (I), t. 32, nr 24 975, s. 53-55.

${ }^{41}$ PSZRI (I), t. 4, nr 2456, s. 766-767; t. 5, nr 3006, s. 251-253.

${ }^{42}$ D.O. Sierow, Sudoustrojstwo..., s. 111.

${ }^{43}$ PSZRI (I), t. 4, nr 2331, s. 643-644.

${ }^{44}$ PSZRI (I), t. 5, nr 2786, s. 89-90; nr 3006, s. 252.
} 
z 21 września 1732 r. ${ }^{45}$. Przewidywała ona umieszczenie jednego oberfiskała przy Kolegium Wojny, a dalszych dwóch przy armiach. Natomiast w ramach każdej dywizji i garnizonu powinien funkcjonować jeden fiskał. Urzędników tych podporządkowano generałowi inspektorowi i inspektorom wojskowym ${ }^{46}$.

\subsection{Rola dowódców wyższego szczebla w wykonywaniu sądownictwa wojskowego i cywilnego}

Już w Krótkim Artykule został wprowadzony tryb, zgodnie z którym wyroki zasądzone przez kriegsrechty podlegały zatwierdzeniu dowódców liniowych wyższego szczebla, czyli generałów feldmarszałków lub generałów ${ }^{47}$. Analogiczne rozwiązanie proceduralne ustawodawca przewidział w Krótkim ujęciu procesów..., ale jedynie w stosunku do orzeczeń końcowych, jakie zapadły w szczególnie ciężkich przestępstwach ${ }^{48}$. Podniesienie znaczenia $\mathrm{w}$ systemie orzecznictwa wojskowego głównodowodzących nastąpiło w dekretach z 3 marca 1719 r. oraz 24 lipca 1721 r., gdzie umieszczono klauzulę o konieczności konfirmowania przez nich wszystkich werdyktów zasądzonych przez sądy generalne i pułkowe ${ }^{49}$. Dopiero wtedy mogły one trafić do Kolegium Wojny lub cesarza i tym samym nabrać mocy prawnej. Koniec końców, dążąc do ukrócenia nadmiernej biurokracji, wiążącej się z procedurą konfirmacji wyroków śmierci, 11 listopada $1724 \mathrm{r}$. ustawodawca nadał dowódcom korpusów prawo do ostatecznego zatwierdzania wyroków, jakie kriegsrechty wydały w sprawach podoficerów i szeregowców ${ }^{50}$.

Wzrost kompetencji sądowych feldmarszałków i generałów, którym podlegały armie i korpusy nastąpił w $1812 \mathrm{r}$. w związku ze zmianami organizacyjnymi w siłach lądowych, stanowiącymi reakcję władz na zbliżającą się wojnę z Francją. W myśl opublikowanych wówczas Zarządzeń w zakresie dowodzenia Wielka Armia Czynna przy strukturze tej, jak również w ramach poszczególnych korpusów i dywizji, zaczęto powoływać na podstawie rozkazów głównodowodzących audytoriaty polowe ${ }^{51}$. Organy te, przewidziane tylko na czas wojny, funkcjonowały jednak na wielu obszarach Rosji (zazwyczaj kresowych) także po ustaniu

${ }^{45}$ PSZRI (I), t. 8, nr 6187, s. 926-928.

${ }^{46}$ Ibidem, s. 926.

${ }^{47}$ Artikut Kratkij ..., s. 26.

${ }^{48}$ PSZRI (I), t. 5, nr 3006, s. 408.

${ }^{49}$ PSZRI (I), t. 5, nr 3315, s. 670; t. 6, nr 3807, s. 410-411.

${ }^{50}$ PSZRI (I), t. 7, nr 3589, s. 361. Prawo to zostało w zasadzie powtórzone w ukazie z 25 czerwca 1779 r., z tym że prawodawca przydzielał prerogatywy do ostatecznej konfirmacji werdyktów sądowych: generałom dowodzącym korpusami, gubernatorom i oberkomendantom jedynie w sprawach o mało ważne przestępstwa, jakich dopuścili się podoficerowie i szeregowcy; zob. PSZRI (I), t. 20 , nr 14889 , s. $846-847$.

${ }^{51} \operatorname{PSZRI}(\mathrm{I})$, t. 32, nr 24975, s. 75-78; SWM, t. 12, k. 1, cz. 2, s. 116. 
operacji militarnych, gdy rząd ogłaszał na ich terenie stan wojenny. Decydujące znaczenie w pracy audytoriatów polowych mieli głównodowodzący, uprawnieni do wszczynania rozpraw, mianowania członków składów orzekających, zatwierdzania oraz zmiany wyroków, jak i nakładania na winnych sankcji karnych, bez udziału instytucji wymiaru sprawiedliwości (w tym również cywilnych). Fakt podlegania audytoriatom polowym nie tylko wojskowych wszystkich stopni oraz całego personelu pomocniczego, ale również ludności cywilnej zamieszkującej na obszarach okupowanych przez rosyjskie siły zbrojne, zapewniał dowódcom najwyższego szczebla nieograniczoną wprost władzę na podległych im terytoriach. Stąd brała się samowola administracji wojskowej (i cywilno-wojskowej), widoczna na przykład w Królestwie Polskim po wypadkach z lat 1830-1831, jak również w dobie powstania styczniowego. Fakt, że reżim karny przewidziany prawem na czas wojny był łagodniejszy od przewidzianego na czas pokoju, sprzyjał eskalacji ekscesów, jakich dopuszczali się żołnierze carscy wobec ludności miejscowej, zwłaszcza że oficerowie zazwyczaj patrzyli na takie incydenty przez palce.

Po zakończeniu walk z Napoleonem ogromne prerogatywy dowódców wyższych związków taktyczno-operacyjnych do decydowania o winie lub niewinności wojskowych utrzymano w mocy, bez względu na zakończenie działań wojennych. Dwunastego grudnia 1815 r. prawodawca nadał stojącym na czele armii i samodzielnych korpusów naczelnikom prawo do oddawania pod sąd wszystkich podwładnych, do szarży generała włącznie, oraz zatwierdzania i egzekwowania werdyktów sądów wojskowych w stosunku do wszystkich spraw z udziałem oficerów (do stopnia pułkownika) oraz niższych rang, w których oskarżony nie podlegał pozbawieniu życia lub rangi ${ }^{52}$. Szerokie uprawnienia generałów feldmarszałków i generałów w przedmiocie konfirmowania i zamieniania kar zasądzonych w oparciu o Artykut Wojskowy (prawo obligowało kriegsrechty do orzekania właśnie w oparciu o ten dokument) powodowało, że sądy i głównodowodzący stosowali w stosunku do jednej sprawy różne ustawy. $\mathrm{Z}$ reguły ci ostatni orzekali w oparciu o nowszy materiał prawodawczy, który dzięki temu wypierał nieodpowiadający duchowi nowych czasów kodeks opracowany przez Piotra $\mathrm{I}^{53}$. Na tym polegała pozytywna rola wyższych dowódców w orzecznictwie wojskowym, jeśli uwzględnić całościowy stan rosyjskiego wymiaru sprawiedliwości. Z drugiej

52 PSZRI (I), t. 33, nr 26022, s. 404. Niektórzy głównodowodzący uzyskiwali w warunkach specjalnych prerogatywy do konfirmacji wyroków w odniesieniu do niektórych kategorii spraw, które w normalnym trybie podlegały rewizji Audytoriatu Generalnego. Na przykład, na mocy ukazu z 9 maja 1817 r. dowódca samodzielnego korpusu gruzińskiego generał Aleksiej Jermołow uzyskał władzę zatwierdzania i wykonywanie wyroków śmierci w odniesieniu do podoficerów i szeregowców, którym udowodniono niezgodne z rozkazami kontakty z narodami górskimi, wśród których szalała dżuma; zob. PSZRI (I), t. 34, nr 26845, s. 280-281.

${ }_{53} S W M$, t. 12, cz. 2, k. 1, s. 132. 
wszakże strony, chociaż za panowania cara-reformatora ujawniła się tendencja do odchodzenia od praktykowanej od XVII w. zasady: „kto rządzi, ten sądzi”, to rola dowodzących armiami i korpusami generałów feldmarszałków i generałów we wszystkich stadiach wojskowego procesu sądowego pozostawała nadal wręcz nieograniczona. Znane są wypadki - na co zwrócił uwagę N. Pietuchow zsyłania na katorgę, na podstawie rozkazu głównodowodzącego, całych składów orzekających za zasądzenie w sprawie zbyt łagodnego wyroku ${ }^{54}$. Począwszy od 1815 r. rozprawy prowadzone przez kriegsrechty zaczęły przypominać śledztwa wstępne. Z kolei do generałów feldmarszałków i generałów należało rozpatrzenie istoty sprawy i wydanie werdyktu końcowego, co w praktyce kończyło się nakładaniem za takie same przestępstwa różnych sankcji karnych. Powodowało to ogólne zamieszanie w systemie orzecznictwa, w którym rola sądów wojskowych została w praktyce sprowadzona do zera.

\subsection{System podsądności oficerów i niższych rang oraz uprawnienia orzecznicze wojskowych organów wymiaru sprawiedliwości}

Prawo instytucji sądowych do orzekania w sprawach z udziałem wojskowych w Rosji z czasem się zmieniało. Stosownie do ukazu z 3 marca 1726 r. kriegsrechty generalne i pułkowe mogły rozpatrywać tylko te czyny karalne, których oficerowie, podoficerowie i szeregowcy dopuścili się przeciwko regulaminom służby wojskowej. W odniesieniu do wszystkich innych przewinień podlegali oni sądom cywilnym ${ }^{55}$. Wyjątek ustawodawca zrobił jedynie w stosunku do składu osobowego formacji gwardyjskich, przede wszystkim z racji ich specjalnego statusu w carskich siłach zbrojnych. Otóż oficerów i niższe rangi gwardii, niezależnie od rodzaju przewinienia, mogły sądzić wyłącznie wojskowe składy orzekające. Faktycznie jednak już w 1727 r. przepis ten przestał obowiązywać. Istotną zmianę w tej kwestii przyniosło panowanie Anny Iwanowny, która w 1733 r. zabroniła sądzić wojskowych w cywilnych organach sądowniczych, nakazując odsyłanie ich spraw do pułków macierzystych ${ }^{56}$.

Dalsze modyfikacje przyniosło panowanie Katarzyny II. Zgodnie z wydaną 7 listopada 1775 r. Ustawa dla zarządu guberniami, w której po raz pierwszy w rosyjskim prawodawstwie dokonano ścisłego rozgraniczenia pomiędzy podsądnością cywilną i karną, sprawy cywilne z udziałem oficerów i żołnierzy poddano jurysdykcji sądów powszechnych (dokładnie - Sądów Nadwornych w Sankt Petersburgu i Moskwie), co w praktyce oznaczało, że krieigsrechty stały się or-

\footnotetext{
${ }^{54}$ N.A. Pietuchow, op.cit., s. 41.

${ }_{55}$ PSZRI (I), t. 7, $\mathrm{nr} 4843$, s. 575-576.

${ }^{56} S W M$, t. 12, cz. 1, k. 1, s. 144.
} 
ganami orzekającymi jedynie w kwestiach karnych ${ }^{57}$. Pewne odstępstwo od tej praktyki nastąpiło w 1782 r., kiedy na mocy ukazu z 21 stycznia prawodawca wyraził zgodę na to, aby sądy powszechne wyrokowały w przestępstwach karnych z udziałem wojskowych, ale tylko wtedy, gdy podsądny przebywał z dala od swej jednostki, a w pobliżu nie znajdowały się żadne inne formacje zbrojne ${ }^{58}$. W takim wyjątkowym przypadku oficera, podoficera i żołnierza mogły sądzić cywilne instytucje wymiaru sprawiedliwości, ale sankcję karną były one zobowiązane wymierzyć na podstawie ustaw wojskowych. Trafiała ona następnie, w celu konfirmacji, bezpośrednio do gubernatorów lub generał-gubernatorów korzystających $\mathrm{z}$ uprawnień naczelników w stosunku do pułków garnizonowych, z pominięciem właściwych instancji cywilnych. Tylko w razie ciężkich zbrodni końcowe orzeczenia sądów cywilnych gubernatorzy kierowali do zatwierdzenia do Kolegium Wojny $^{59}$. Jako uzupełnienie do ukazu z 21 stycznia 1782 r. opublikowano wyjaśnienie, że powszechnym organom sądowym podlegali tylko podoficerowie oraz szeregowcy, ale tylko ci niewywodzący się ze stanu szlacheckiego ${ }^{60}$.

Ogólnie rzecz ujmując, za rządów Katarzyny II wojskowi nie zostali w dziedzinie prawodawstwa karnego podporządkowani wyłącznie armijnym organom wymiaru sprawiedliwości. Niemniej wyodrębnienie podsądności wojskowej, jakie wówczas nastąpiło, stanowiło pochodną poglądów Katarzyny II na to, że każdy powinien być sądzony przez równych sobie. Takie podejście znalazło później odzwierciedlenie w działalności sądów powszechnych, gdzie szczególnie mocno został uwypuklony czynnik stanowy ${ }^{61}$.

Dopiero Paweł I w dekrecie z 24 czerwca 1797 r. podporządkował ostatecznie wszystkich oficerów, podoficerów i szeregowców organom sądownictwa sił zbrojnych $^{62}$. Gubernatorzy nie mogli już ingerować w pracę tych ostatnich, a obecność cywilów podczas rozpraw toczących się w kriegsrechtach dopuszczano jedynie w przypadku znieważenia ich przez oficerów i żołnierzy niższej rangi. Oznaczało to utrzymanie funkcjonujących od czasów Katarzyny II sądów mieszanych. Legislator upoważnił kriegsrechty do rozpatrywania tylko spraw karnych, niemniej w praktyce musiały się one zajmować także sprawami natury cywilnej, bowiem

${ }^{57}$ PSZRI (I), t. 20, nr 14392, s. 296. Notabene, wszelkie powództwa przeciwko wojskowym odnoszące się do takich dziedzin prawa cywilnego, jak prawo zobowiązań i majątkowe, nie podlegały kompetencjom sądów wojskowych również we wcześniejszych latach; zob. SWM, t. 12, cz. 1, k. 1, s.146.

${ }^{58}$ PSZRI (I), t. 23, nr 17016, s. 300-301.

59 Ibidem, s. 301.

${ }^{60} S W M$, t. 12, cz. 1, k. 1, s. 146.

${ }^{61}$ Ibidem.

${ }^{62}$ PSZRI (I), t. 24, nr 18017, s. 636-637. 
ukaz z 24 stycznia 1797 r. powołujący do życia Audytoriat Generalny nadawał mu kompetencje do orzekania tak w sprawach karnych, jak i cywilnych ${ }^{63}$.

Rozwiązania przyjęte przez Pawła I przetrwały w zasadzie bez zmian do 1867 r. Podległość oficerów i żołnierzy w stosunku do armijnych organów sądowniczych nie tylko nie osłabła, ale znacząco wzrosła w czasach panowania Aleksandra I oraz Mikołaja I, kiedy w kręgu podsądności wojskowego wymiaru sprawiedliwości znalazło się wiele kategorii osób niezwiązanych z siłami zbrojnymi. Proces ten zapoczątkował już Piotr I. Na mocy dwóch aktów prawnych sygnowanych przez cesarza 6 listopada 1724 r., regulujących ogół zagadnień wiążących się z organizacją sądownictwa oraz procedurami karnymi w związku z wyznaczaniem kwater dla sił lądowych, dowódców pułków obarczono powinnością kontroli cywilnej administracji lokalnej i w pierwszej kolejności przebiegu poboru podatku podusznego, przeznaczonego na utrzymanie jednostek, z czym wiązał się również bezpośredni nadzór armii nad wszystkimi osobami zamieszkującymi na obszarach kwaterowania poszczególnych pułków ${ }^{64}$. Stosownie do powyższych obowiązków ustawodawca nadał pułkownikom uprawnienia do sądzenia i karania lokalnej ludności cywilnej, co odbywało się w oparciu o skargi o znieważenie składane na jej przedstawicieli przez oficerów i żołnierzy. W procesie $\mathrm{z}$ udziałem chłopa powinien brać udział komisarz ziemski. Jeśli podsądnym był szlachetnie urodzony, wymagano obecności dwóch miejscowych szlachciców. Sądy pułkownikowskie nie mogły orzekać w poważniejszych sprawach karnych, które przekazywano sądom nadwornym oraz rozprawach przeciwko mieszkańcom miast. Ci ostatni podlegali własnemu wymiarowi sprawiedliwości, a jeśli weszli w konflikt z wojskowymi, to w sądach miejskich przewidziano miejsce dla dwóch oficerów ${ }^{65}$. Sądy pułkownikowskie, będące mieszanymi instytucjami orzekającymi, uległy likwidacji w 1726 r., ale pojawiły się ponownie w 1764 r. wraz z wydaniem Instrukcji dla pułkownika pułku piechoty ${ }^{66}$. Po śmierci pierwszego rosyjskiego imperatora zaczął się zwiększać zakres podsądności subiektywnej, czyli personalnej kriegsrechtów. Od 27 kwietnia 1761 r. ich jurysdykcji podporządkowano pracowników resortu górniczego, którym nadano wówczas stopnie wojskowe, przez co uzyskali taki sam status jak oficerowie i żołnierze ${ }^{67}$. Sześć lat później (15 kwietnia 1767 r.) upoważniono sądy pułkowe i generalne do ferowania wyroków w sprawach urzędników przeprowadzających pomiary ziemskie ${ }^{68}$.

\footnotetext{
63 Ibidem, s. 637; PSZRI (I), t. 24, nr 17 757, s. 301.

64 PSZRI (I), t. 7, nr 4533, s. 310-318; nr 4534, s. 318-324.

65 PSZRI (I), t. 7, nr 4533, s. 311-312; nr 4534, s. 320-321.

66 PSZRI (I), t. 16, nr 12289, s. 976-977.

${ }^{67}$ PSZRI (I), t. 15, nr 11241, s. 698-699.

${ }^{68}$ PSZRI (I), t. 8, nr 12870 , s. 83-85.
} 
Aleksander I objął działalnością organów sądownictwa armijnego cały personel Zarządu Linii Komunikacyjnych, co było wynikiem utworzenia 21 września 1810 r. w tym departamencie Korpusu Inżynierów, jak i osoby zatrudnione w stadninach wojskowych (rozporządzenie z 16 listopada 1819 r.) ${ }^{69}$. Dwudziestego ósmego listopada $1821 \mathrm{r}$. władze objęły działaniem wojskowych procedur sądowych pracowników resortu górniczego, który uzyskał ostatecznie organizację wojskową $^{70}$. Co więcej, za panowania Aleksandra I, w związku z różnego rodzaju wystąpieniami społecznymi, zdarzały się przypadki przesyłania spraw z udziałem ludności cywilnej do kriegsrechtów pułkowych i generalnych. W taki sposób osądzono na przykład w 1813 r. właścicieli ziemskich z guberni mińskiej, którzy nie wykonali polecenia rządu i nie oddali zdobycznej broni oraz jeńców z Wielkiej Armii napoleońskiej, czy też buntujących się przeciwko swym właścicielom w 1820 r. na ziemiach Obwodu Wojska Dońskiego i guberni jekaterynowsławskiej chłopów. W 1823 r. jurysdykcji wojskowych organów wymiaru sprawiedliwości poddano mieszkańców Zakaukazia ${ }^{71}$. Tego typu posunięcia brały się zapewne z doświadczeń wyniesionych z walk z Francją i jej sojusznikami, kiedy moc prawną uzyskały Zarzadzenia w zakresie dowodzenia Wielka Armia Czynna. Zgodnie z literą tego dokumentu, w czasie działań bojowych sądownictwu wojskowemu, za wykroczenia wyszczególnione w Polowym kodeksie karnym, podlegali nie tylko wszyscy oficerowie, żołnierze i służący w armii urzędnicy oraz cały personel pomocniczy, ale również szpiedzy i mieszkańcy ziem opanowanych przez oddziały carskie ${ }^{72}$.

Wystąpienie dekabrystów, insurekcja w Polsce, rozruchy chłopskie, powstanie na Kaukazie i wojna turecka spowodowały, że Mikołaj I obawiający się ruchów narodowowyzwoleńczych i rewolucyjnych znacząco zwiększył, w porównaniu z poprzednim panowaniem, zakres oddziaływania sądownictwa wojskowego. Do 1859 r. podlegało mu aż 66 kategorii osób zamieszkujących na obszarach Cesarstwa, z czego 26 kategorii za wszystkie czyny niezgodne z prawem, zaś 40 kategorii jedynie za niektóre rodzaje przestępstw. Do pierwszej grupy należeli między innymi: 1) urzędnicy w stanie spoczynku pełniący służbę w jednostkach dyslokowanych w Królestwie Polskim; 2) funkcjonariusze miejskich komend policyjnych i Korpusu Leśniczych; 3) pracownicy resoru górniczego i stadnin państwowych; 4) inspektorzy pocztowi w stopniach podoficerskich oraz 5) skazani za włóczęgo-

${ }^{69}$ PSZRI (I), t. 31, nr 24356, s. 361-362; t. 36, nr 27 981, s. 379-380.

70 PSZRI (I), t. 37, nr 28820, s. 930-931. Departament górniczy przy ministerstwie finansów powstał 13 lipca 1806 r. W opublikowanym wówczas Regulaminie Górniczym ustawodawca przewidywał powołanie sądu wojskowego do rozpatrywania spraw karnych z udziałem pracowników tego resortu; zob. PSZRI (I), t. 29, nr 22208, s. 611-612.

${ }^{71} S W M$, t. 12, cz. 2, k. 1, s. 134-135.

${ }^{72}$ PSZRI (I), t. 32, nr 24975, s. 78-80. 
stwo z piętnem „B” i osadnicy zamieszkujący tereny leżące za rzeką Kubań. Z kolei wśród zakwalifikowanych do drugiej grupy znaleźli się: 1) personel Kompanii Rosyjsko-Amerykańskiej; 2) uczestniczący w pojedynkach studenci uniwersytetu w Dorpacie; 3) funkcjonariusze służb odpowiedzialnych za wprowadzanie kwarantanny w związku z pojawieniem się epidemii; 4) mierniczowie źle wykonujący swą pracę; 5) naczelnicy okręgowi i wiejscy oraz pisarze resortu majątków państwowych; 6) mieszkańcy: Anapy, Noworosyjska i Suchumi; 7) ludy koczownicze z guberni stawropolskiej i Kirgizi z Kraju Orenburskiego; 8) chłopi buntujący się przeciwko swym panom; 9) osoby, które złamały przepisy akcyzowe i zasady wydobywania soli oraz dokonywały nielegalnego wyrębu drzewa stanowiącego budulec okrętowy; 10) złodzieje metali szlachetnych w zakładach uralskich oraz 11) wszystkie osoby biorące udział w powstaniu listopadowym ${ }^{73}$. W sumie za rządów Mikołaja I zasięg podsądności kriegsrechtów objął praktycznie wszystkich urzędników i funkcjonariuszy cywilnych zatrudnionych w wojskach lądowych, marynarce wojennej, jak również resortach posiadających organizację wojskową. Co do tych ostatnich, należy zaznaczyć, że powołany 30 stycznia 1839 r. przy Ministerstwie Majątków Państwowych Korpus Leśniczych, otrzymał nawet - jak armia - swój własny audytoriat ${ }^{74}$. Do tego dochodzili jeszcze w większości nierosyjscy mieszkańcy obszarów przygranicznych, zwłaszcza obywatele byłej Rzeczypospolitej polsko-litewskiej oskarżeni o wrogą działalność antypaństwową i oficjele pracujący w rozmaitych agendach państwowych. Zatem Mikołaj I posłużył się wojskowymi instytucjami wymiaru sprawiedliwości do intensyfikacji represji karnych oraz umocnienia w kraju ustroju autokratycznego.

\subsection{Organizacja wojskowego procesu sądowego}

Dwudziestego pierwszego lutego 1697 r. ukazał się dekret carski $O$ zniesieniu $w$ sprawach sadowych konfrontacji świadków, o bytności zamiast nich przestuchania i dochodzenia, o świadkach, o wyznaczaniu owych, o przysiędze, o karaniu fatszywych świadków i o opłatach celnych ${ }^{75}$. Znosił on istniejący do tej pory model rozprawy $\mathrm{z}$ udziałem stron i wprowadzał nowe procedury utrwalające $\mathrm{w}$ armijnym prawodawstwie procesowym elementy biurokratyczne oraz - co ważniejsze tzw. rozysk, czyli postepowanie inkwizycyjne. Jego szczegółowa reglamentacja nastąpiła w Krótkim ujęciu procesów... z 1715 r. Zgodnie z tym dokumentem wojskowy proces sądowy dzielił się na trzy stadia. Pierwsze rozpoczynało się od wniesienia skargi przez powoda do tego naczelnika wojskowego, który miał prawo do powołania składu orzekającego. Potem publikowano

\footnotetext{
${ }^{73} S W M$, t. 12, cz. 2, k. 1, s. 143-144.

${ }^{74}$ PSZRI (II), t. 31, nr 31155, s. 1014-1017.

${ }^{75}$ PSZRI (I), t. 3 nr 1572, s. 278-279.
} 
w formie pisemnej informację o rozprawie oraz oświadczenie o konieczności stawienia się zainteresowanych osób przed kriegsrechtem. Po otwarciu posiedzenia sądu powód wyłuszczał swe roszczenia, zaś oskarżony ustosunkowywał się do nich, co kończyło pierwszą fazę rozprawy. W sprawach karnych prawo nie dopuszczało możliwości reprezentowania stron przez ich przedstawicieli, określanych, jako ,adwokaci” i ,pełnomocnicy”. Norma ta nie obowiązywała w przypadku powództwa cywilnego, kiedy w razie choroby strony mogły wysłać na rozprawę swych plenipotentów ${ }^{76}$.

Etap drugi, tzw. „ferger” (wysłuchanie sprawy), stanowił właściwą rozprawę i ciągnął się do chwili wydania końcowego werdyktu. Rozpoczynał się od analizy materiału dowodowego. Istniały cztery typy dowodów, mianowicie: własne przyznanie się do winy, zeznania świadków, dowody pisemne i przysięga. Najważniejszym spośród nich było przyznanie się oskarżonego do winy. Aby to osiągnąć, legislator przewidywał możliwość użycia przymusu w postaci tortur, i to nie tylko wobec podsądnego, ale równie w stosunku do świadków. Rzecz jasna, ustawa ograniczała zasady ich stosowania. Torturować można było tylko określoną ilość razy, a rodzaj wykorzystanych środków przymusu zależał od rangi, stanu społecznego, wieku oraz stanu zdrowia delikwenta. Informacje uzyskane podczas tortur powinny były zostać potwierdzone przez inne dowody. Zeznania świadków nie posiadały jednakowej wartości. Dominowała tzw. formalna teoria dowodowa. Wartość każdego dowodu została określana w prawie i uznawano ją za niezmienną. Dlatego zeznania mężczyzn ceniono wyżej niż zeznania kobiet, ludzi zamożnych - wyżej niż biednych, osób wykształconych - wyżej niż niewykształconych, duchownych - wyżej niż świeckich. Ustawa precyzowała też krąg osób, które nie mogły być świadkami. Do tej kategorii należeli krzywoprzysięzcy, wyklęci przez Cerkiew, wygnani z kraju oraz skazani za kradzież, zabójstwo, rozbój i tym podobne przestępstwa. Zazwyczaj świadków mógł przesłuchiwać tylko sędzia i tylko podczas procesu. Złożenie fałszywych zeznań karano obcięciem palców u ręki. Oprócz zeznań ustnych, dopuszczano możliwość sięgania po dowody pisemne, w rodzaju wpisów do ksiąg miejskich, sądowych i handlowych, zobowiązań dłużnych, pism urzędowych i innego rodzaju dokumentacji. Prawo wymagało ich potwierdzenia przez przysięgę, uznawaną za najgorszy rodzaj dowodu. W skrajnych wypadkach, gdy nie istniał inny sposób udowodnienia postawionych zarzutów, stosowano tzw. przysięgę oczyszczającą. Oskarżonego, który ją złożył, uznawano za niewinnego. Odmowa oznaczała automatycznie przyznanie się do winy. Po analizie materiału dowodowego sąd przechodził do wydawania wyroku, który zapadał większością głosów. W razie równoważenia się głosów „za” i „przeciw”, decydowała opinia prezesa. Werdykt sporządzano w formie pisemnej, z obowiąz-

${ }^{76}$ PSZRI (I), t. 5, nr 3006, s. 389-392. 
kiem sygnowania go przez przewodniczącego, wszystkich sędziów oraz audytora. Następnie sekretarz, w obecności stron, publicznie odczytywał wyrok. Sentencje końcowe, jakie zapadły w sprawach z użyciem tortur, podlegały zatwierdzeniu przez feldmarszałka lub generała. Ci ostatni mogli zmienić wymiar zasądzonej przez sąd kary. Prawo wprowadzało tryb apelacyjnej rewizji wyroku sądowego. Zatem wyrok kriegsrechtu pułkowego można było zaskarżyć do sądu generalnego, który jako wyższa instancja rozpatrywał sprawę od nowa ${ }^{77}$. Faktycznie - jak zaznaczono już powyżej - norma ta była martwą literą, podobnie jak zapis o rozpatrywaniu przez wojskowe organy sprawiedliwości spraw cywilnych. Zaskarżenie werdyktu sądu generalnego, jeśli nawet doszłoby do skutku, to i tak nie dałoby pozytywnego rezultatu, bowiem feldmarszałek jako wyższy naczelnik wojskowy z reguły sprawował funkcję prezesa składu orzekającego. Ostatnia faza procesu, tzw. „kriegsrecht” (wydanie wyroku), trwał od ogłoszenia sentencji końcowej aż do chwili jej wykonania ${ }^{78}$.

Krótkie ujęcie procesów... zwykło się uznawać za podstawowy akt prawny z zakresu rosyjskiego wojskowego ustawodawstwa procesowego. Regulacja ta znacznie bardziej szczegółowo niż wydane wcześniej ustawy (głównie Krótki Artykul) precyzowała zagadnienia związane z przebiegiem rozprawy sądowej, zasadami uchwalania, uchylania i nabierania mocy prawnej przez zasądzony wyrok oraz kwestie dotyczące sytuacji procesowej podsądnego, świadków i audytorów. Jednocześnie w kodeksie tym zostały utrwalone fundamenty i tryb stosowania tortur wobec podsądnego i świadków, z dokładnym określeniem kręgu osób, które mogły występować w roli tych drugich ${ }^{79}$. Sądy wojskowe uzyskały wprawdzie prerogatywy do analizowania spraw karnych i cywilnych, jednak dokument, o którym mowa, nie wprowadzał rozgraniczenia na proces karny i cywilny, a kriegsrechty zajmowały się sprawami z oskarżenia prywatnego i publicznego, opierając się na jednakowym trybie postepowania ${ }^{80}$. Z drugiej strony legislator oddzielił armijne organy wymiaru sprawiedliwości od sądów powszechnych ${ }^{81}$. Po raz pierwszy w rosyjskiej praktyce sądowniczej pojawiła się zasada domniemania niewinności, jak również - niemająca praktycznego zastosowania - instytucja „salvus conductus”, czyli prawne gwarancje umożliwiające stawienie się na rozprawie tym oskarżonym, którzy ukrywali się przed organami ścigania ${ }^{82}$. Krótkie ujęcie procesów... uściślało także zagadnienie usuwania sędziów ze składów orzekających. Mogło to nastąpić wtedy, gdy znajdowali się oni w konflikcie oso-

\footnotetext{
77 Ibidem, s. 392-407.

78 Ibidem, s. 407-411.

79 D.O. Sierow, Wojenno-ugołownoje..., s. 169.

80 N.A. Pietuchow, op.cit., s. 42.

81 PSZRI (I), t. 5, nr 3006, s. 383.

82 Ibidem, s. 403-406.
} 
bistym lub byli w zmowie z którąś ze stron procesu oraz jeśli istniały pomiędzy nimi a podsądnym bądź powodem zobowiązania dłużne ${ }^{83}$.

Rewizja wszystkich wyroków w sprawach karnych wydanych przez kriegsrechty, aż do chwili nabrania przez nie mocy prawnej następowała w drodze ich konfirmacji przez feldmarszałków i generałów, stojących na czele armii oraz korpusów. Tak zwany rewizyjno-rozstrzygający tryb weryfikacji końcowych orzeczeń sądowych, funkcjonujący w państwie carów od XV w. do drugiej ćwierci następnego stulecia, przywrócił Piotr I. Polegał on na tym, że werdykty sądów pierwszej instancji (kriegsrechtów pułkowych w siłach zbrojnych) w pewnej kategorii spraw podlegały obowiązkowemu skierowaniu do zatwierdzenia przez instytucję orzekającą wyższej instancji lub wyższy organ administracyjny (w armii dowódcy szczebla armijnego bądź korpusowego). Wraz z sentencją sądową trafiały do nich akta sprawy albo, co zdarzało się częściej, wyciągi z nich. Odpowiedni organ rewizyjny mógł wyrok uprawomocnić, uchylić (z jednoczesnym odesłaniem sprawy do sądu pierwszej instancji) bądź zmienić (czyli złagodzić albo zaostrzyć sankcję). Generalnie rzecz ujmując, w trybie rewizyjno-rozstrzygającym orzeczenia końcowe nabierały mocy prawnej dopiero po ich zatwierdzeniu przez wyższą instancję sądowniczą lub administracyjną ${ }^{84}$. Wprowadzanie tej procedury do systemu orzecznictwa wojskowego następowało stopniowo. Prawodawca wspominał o niej już w Krótkim Artykule, a potem Krótkim ujęciu procesów..., ale jej ostateczna reglamentacja nastąpiła w ukazach opublikowanych niezależnie od tych aktów prawnych w latach $1719-1724^{85}$. W zależności od szarży i pochodzenia społecznego oskarżonego oraz rodzaju zasądzonej kary ostateczna konfirmacja werdyktów, jakie zapadły w wojskowych sprawach karnych, należała do głównodowodzących armiami i korpusami, Kolegium Wojny, cesarza, zaś od 1797 r. także do Audytoriatu Generalnego.

Tymczasem 5 listopada 1723 r. wyszedł dekret $O$ formie sądu likwidujący proces inkwizycyjny i przywracający rozprawę z udziałem stron $\mathrm{w}$ odniesieniu do spraw karnych oraz cywilnych tak w sądach wojskowych, jak i powszechnych ${ }^{86}$. W akcie tym ustawodawca dążył do wprowadzenia ustnego przewodu sądowego, poszerzenia uprawnień powoda i podsądnego do posiadania swych przedstawicie-

${ }^{83}$ Ibidem, s. 387-388.

${ }^{84}$ D.O. Sierow, Riewizionno-rieszajuszczij porjadok w ugołownom prociessie Rossii konca XV - pierwoj czetwierti XVIII ww., „Żurnał rossijskogo prawa” 2008, nr 6, s. 102. Istota trybu rewizyjnego w rosyjskim, karnym sądownictwie powszechnym została przybliżona w: I.S. Dikariew, Riewizja w istorii rossijskogo ugołownogo sudoproizwodstwa, „Probliemy tieorii i istorii gosudarstwa i prawa" 2012, nr 2 (17), s. 62-65.

${ }^{85}$ Artikut Kratkij ..., s. 26; PSZRI (I), t. 5, nr 3006, s. 408-409; PSZRI (I), t. 5, nr 3315, s. 670; t. 6 , nr 3807 , s. $410-411 ;$ t. 7 , nr 3589, s. 361 .

${ }^{86}$ PSZRI (I), t. 7, nr 4344, s. 147-150. 
li podczas rozprawy, wprowadzenia środków przeciwko nadmiernej biurokratyzacji procedur, szczególnie w zakresie terminowości wzywania stron przed oblicze sądu, z podaniem prawnych przyczyn ich nieobecności. Faktycznie ta regulacja, całkowicie sprzeczna $z$ dotychczasowym ustawodawstwem procesowym, stanowiła tylko próbę jego rozwinięcia, a nie całkowitej modyfikacji. Dlatego, zdaniem niektórych autorów, korzystano z niej tylko przy rozstrzyganiu spraw cywilnych, $\mathrm{z}$ kolei podstawą orzecznictwa w kwestiach karnych było nadal Krótkie ujęcie procesów..., i to zarówno w sądach wojskowych, jak i powszechnych ${ }^{87}$. Jak pokazała praktyka, po śmierci Piotra I aż do reformy z 1867 r. wymiar sprawiedliwości rosyjskich sił lądowych zdominował całkowicie proces inkwizycyjny. Katarzyna II próbowała jedynie usprawnić pracę kriegsrechtów, grożąc w ukazie z 1779 r. sędziom i przede wszystkim audytorom odpowiedzialnością prawną za prowadzenie procesów w sposób chaotyczny, niezgodny z literą obowiązujących ustaw $^{88}$. Monarchini starała się ponadto rozstrzygnąc zagadnienie dotyczące teorii dowodowej w procesie karnym, niezbyt dokładnie wyłożonym w Krótkim ujęciu procesów.... W związku z tym, stosownie do tez Nakazu opublikowanego w 1766 r. na potrzeby kolejnej komisji kodyfikacyjnej, zabroniła w dekrecie z 1 stycznia 1782 r. stosowania tortur w sądach wojskowych, co jednak uzależniła od zgody naczelników dywizji i gubernatorów (jeśli sprawa odnosiła się do pułków garnizonowych ${ }^{89}$. Dokument ten, podobnie jak niektóre inne wydane przez Katarzynę II akty prawne, miał charakter czysto deklaratywny, przez co nie zyskał praktycznego zastosowania. Piętnastego grudnia 1796 r. wszedł w życie skrócony tryb rozpatrywania przez kriegsrechty mało ważnych wykroczeń, głównie dezer$\mathrm{cj}^{9}{ }^{90}$. Werdykt $\mathrm{w}$ takich przypadkach sędziowie wydawali na podstawie wysłuchania wypisu $\mathrm{z}$ akt, sporządzonego przez audytora $\mathrm{w}$ trakcie przesłuchania oskarżonego, w którym musiała znaleźć się wzmianka o tym, z czyjego rozporządzenia wszczęto sprawę.

Dopiero opublikowanie w 1839 r. Regulaminu wojskowego karnego przyniosło pewne zmiany w armijnych procedurach procesowych, wprowadzając różne rozwiązania dla okresu pokoju i wojny. W warunkach pokojowych orzecznictwo nadal opierało się na przepisach Krótkiego ujęcia procesów..., z nieznacznymi tylko modyfikacjami dotyczącymi dalszego wzrostu roli dowództw wojskowych w systemie wymiaru sprawiedliwości, co faktycznie oznaczało wydawanie wyroków w trybie administracyjnym, a nie sądowym ${ }^{91}$. Natomiast w czasie konfliktu militarnego sędziowie mieli się kierować normami wydanego w 1812 r. Regula-

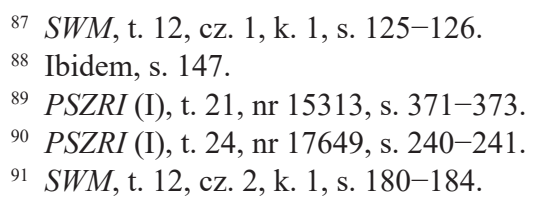


minu sądownictwa polowego, który wprowadzał procedury zupełnie inne od zapisanych w Krótkim ujęciu procesów... ${ }^{92}$. Dokument ten opierał bowiem przewód sądowy na zasadach jawności, ustności, dopuszczeniu obrońców oraz braku obowiązkowego stosowania dowodów formalnych, co oznaczało odejście od pryncypiów procesu inkwizycyjnego. Paradoksalnie, podczas wojny sądownictwo rosyjskich sił zbrojnych korzystało z nowocześniejszych procedur sądowych niż w warunkach pokoju.

Obraz wojskowego prawodawstwa wojskowego byłby niepełny bez uwzględnienia zasad prowadzenia śledztw. Tylko dzięki odpowiednio udokumentowanym materiałom dowodowym kriegsrechty mogły prowadzić rozprawy i orzekać o winie lub niewinności podsądnych. Pierwotnie czynności śledcze wchodziły w zakres obowiązków instytucji sądowych. Sytuacja uległa zmianie dopiero 8 kwietnia 1782 r. wraz z wydaniem Przepisów odnoszacych się do spokoju czyli spraw policyjnych, które powinność tę przenosily na organa policyjne (tzw. Uprawy błagoczinija i pristawów), reprezentujące resort cywilny ${ }^{93}$. Paweł I z kolei polecił, aby wszystkie śledztwa w sprawach z udziałem oficerów i żołnierzy osobiście przeprowadzali audytorzy ${ }^{94}$. Zatem, w końcu XVIII w. śledztwo oddzieliło się ostatecznie od procesu sądowego. Koniec końców, praktyka poszła w tym kierunku, że ciężar działań śledczych spadł na barki specjalnie wyznaczonych urzędników cywilnych, z wyjątkiem przestępstw i wykroczeń, jakich wojskowi dopuścili się w czasie pełnienia służby oraz na terenie obiektów wojskowych (koszar, strzelnic, itp.), kiedy dowództwa jednostek wyznaczały specjalne komisje wojskowo-śledcze, powołując do ich składów oficerów ${ }^{95}$. Kiedy w przestępstwa karne zamieszani byli cywile, armia dopuszczała możliwość udziału w czynnościach śledczych przedstawicieli resortów, którym podlegali podsądni ${ }^{96}$.

\footnotetext{
${ }^{92}$ PSZRI (I), t. 32, nr 24975, s. 75-80.

${ }^{93}$ Ustaw Błagoczinija ili policejskij [w:] Rossijskoje zakonodatielstwo X-XX wiekow, t. 5, Moskwa 1987, s. 331-332, 335, 348.

${ }^{94} S W M$, t. 12 , cz. 1, k. 1, s. 167.

${ }^{95}$ Istoriczeskij oczerk dielatiel'nosti Wojennogo Uprawlienija w Rossii w pierwoje dwadcati-pjati lietije carstwowanija impieratora Alieksandra Nikołajewicza (1855-1880 gg.), t. IV, costawlien gienierat-majoram Szil'dierom i połkownikom Choroszchinym pod rukowodstwom gienierat-liejtnanta Bogdanowicza, S.-Pietierburg 1880, s. 449-450. Niekiedy zakres kompetencyjny komisji wojskowo-śledczych niewiele różnił się od uprawnień kriegsrechtów, będących w istocie komisjami wojskowo-sądowymi. Na mocy ukazu z 23 listopada 1800 r. Paweł I zabronił tym ostatnim wpisywania swych opinii do orzeczeń końcowych, gdyż zadaniem sądu - według cesarza - nie powinno być rozstrzyganie o winie oskarżonego, ale stwierdzenie faktu popełnienia przez niego czynu karalnego i wydanie wyroku z całą surowością prawa, odpowiednio do rangi przestępstwa. Tym samym pod względem swej roli w orzecznictwie kriegsrechty zaczęły przypominać instytucje powoływane do prowadzenia śledztw; zob. PSZRI (I), t. 24, nr 19663, s. 400.

${ }^{96} S W M$, t. 12 , cz.2, k. 1, s. 181.
} 


\subsection{System kar w prawodawstwie wojskowym}

Wojskowe ustawodawstwo karne w Rosji przed reformą 1867 r. rozwijało się stopniowo, przechodząc kilka etapów. Pierwszy, trwający do chwili opublikowania w 1715 r. Artykułu Wojskowego, charakteryzował się brakiem jednolitego dla całego państwa armijnego kodeksu karnego. Dlatego instytucje sądowe i administracyjne wymierzając oskarżonym kary musiały kierować się regulacjami różniącymi się od siebie tak pod względem techniki prawnej, jak i podmiotowego zakresu oddziaływania. W zasadzie najwcześniejszym aktem, w którym legislator obszerniej poruszył zagadnienie karalności oficerów i żołnierzy było Ułożenie Szeremietjewa. Wprowadzało ono odpowiedzialność karną za 79 przestępstw, z czego w 59 wypadkach przewidywano karę śmierci, którą dzielono na prostą (powieszenie, odcięcie głowy mieczem) oraz kwalifikowaną (ćwiartowanie), zasądzaną za zdradę, spiskowanie dowódców z podwładnymi i zabójstwo w celach materialnych. Kodeks wspominał również o zaocznej karze śmierci, wykonywanej symbolicznie poprzez przybicie do szubienicy tabliczki z imieniem przestępcy ${ }^{97}$. Oprócz sankcji pozbawienia życia sądy mogły uciekać się do: 1) kar mutylacyjnych: odcięcie nosa za krzywoprzysięstwo, przybicie ręki sprawcy nożem do szubienicy za zadanie komuś rany; 2) ciężkich i lekkich kar cielesnych: bicie knutem i szpicrutami, noszenie naraz - z przerwami - sześciu sztuk muszkietów przez dwie godziny w ciągu kilku następujących po sobie dni; 3) aresztu; 4) konfiskaty majątku i potrącenie określonej kwoty z żołdu; 5) pozbawienia czci poprzez degradację i pozbawienie stanowiska oraz; 6) zadania winowajcy takiej samej szkody, jakiej dopuścił się on wobec poszkodowanego, co należy uznać za odwołanie się do prawa talionu. Złamanie obowiązujących ustaw pod wpływem alkoholu zawsze traktowano jako okoliczność obciążającąą .

Opublikowany kilka lat później Krótki Artykut, w przeciwieństwie do Utożenie Szeremietjewa, wprowadził do ustawodawstwa karnego klarowny wykaz sankcji dyscyplinarnych, z których mogli korzystać dowódcy oddziałów, bez kierowania sprawy do sądów. Mowa o: biciu batogami, osadzeniu w areszcie w kajdanach, noszeniu fuzji, przykuciu do podłogi czy posadzeniu na drewnianego konia. Surowsze środki represyjne dopuszczano tylko po wydaniu odpowiedniego wyroku przez kriegsrechty. Utrzymano - wzorem Ułożenia Szeremietjewa - podział kary śmierci, którą można było zasądzić w aż 65 wypadkach, na prostą (powieszenie) i kwalifikowaną (ćwiartowanie i spalenie). Podobnie sprawa wyglądała w odniesieniu do sankcji majątkowych oraz powodujących trwałe uszkodzenie ciała. Krótki Artykut traktował powtórne złamanie prawa

\footnotetext{
${ }^{97}$ Utożenije ili prawo woinskogo powiedienija... s. 269-294.

${ }^{98}$ Ibidem.
} 
jako okoliczność obciążającą ${ }^{99}$. Szczególnie okrutną karą w przypadku obu omawianych zbiorów praw była decymacja, czyli dziesiątkowanie, sięgająca swymi korzeniami do czasów antycznych. Stosowano ją w niektórych armiach nowożytnych. Władze zamierzały sięgać po ten środek w przypadku popełnienia zbrodni przez całe jednostki, które uciekły z pola bitwy lub bezzasadnie poddały twierdzę albo garnizon, kiedy nie istniała możliwość ukarania jednego bądź kilku delikwentów, znanych z imienia. Wtedy najwyższemu wymiarowi kary podlegał, co dziesiąty, losowo wybrany żołnierz i dowódca niższego szczebla. Głównodowodzących pozbawiano życia od $\mathrm{razu}^{100}$. Ogólnie rzecz ujmując, Utożenia Szeremietjewa oraz Krótki Artykuł były do sobie podobne pod względem asortymentu sankcji represyjnych i zasad ich stosowania.

W następnych latach wydano kilka pomniejszych, choć mających zasięg ogólnokrajowy, regulacji, dotykających kwestii karalności wojskowych za różnego rodzaju przewinienia. Wystarczy wspomnieć chociażby o Punktach dla dowodzacych nad każdym batalionem z 1706 r., gdzie grożono karą śmierci za samowolne oddalenie się z jednostki, Punktach dla składu dowódczego z 1710 r., w których Piotr I udzielał rad na temat zasad utrzymania porządku w armii, czy Regulaminie dla kriegs-komisariatu z 1712 r., zawierającego wskazówki w przedmiocie sądzenia winnych okradania skarbu państwa ${ }^{101}$. Treściwe zestawienie (w jednym sześciopunktowym rozdziale) środków represyjnych znalazło się także w Krótkim ujęciu procesów lub spraw sądowych. Legislator - w porównaniu z wcześniejszymi ustawami - poszerzał w nim i hierarchizował wachlarz kar, do jakich mogli uciekać się przedstawiciele armijnego aparatu sprawiedliwości. Pozbawienie życia mogło nastąpić poprzez rozstrzelanie, odcięcie głowy mieczem, powieszenie, łamanie kołem, ćwiartowanie i spalenie na stosie. Sankcje cielesne dzieliły się na zwyczajne (zamknięcie pod strażą, zakucie w kajdany, uwięzienie o chlebie i wodzie, bicie knutem, chodzenie po drewnianych włóczniach itp.) oraz ciężkie (bicie szpicrutami i knutem, piętnowanie rozżarzonym żelazem, obcinanie uszu, rąk i palców, zsyłka na katorgę). Winnych lekkiego splamienia honoru czekało wygnanie z pułku bądź wydalenie za granicę. Natomiast ogłoszenie łotrem i złamanie szpady nad głową czekało tych wszystkich, którzy dopuścili się ciężkiego pohańbienia godności oficerskiej lub żołnierskiej ${ }^{102}$.

Największe znaczenie dla prawodawstwa karnego w lądowych siłach zbrojnych miał jednak Artykut Wojskowy. Na początku tego dokumentu ustawodawca sprecyzował cele środków represyjnych, które sprowadzały się do odwetu na prze-

\footnotetext{
${ }^{99}$ Artikut Kratkij ..., s. 55-69.

100 Ibidem, s. 68.

101 Spisok s riegłamientow krigs-komisariatu [w:] A.Z. Myszłajewskij, op.cit., s. 89-91; P.O. Bobrowskij, Pietr Wielikij kak wojennyj zakonodatiel', Sankt-Pietierburg 1887, s. 43, 50, 51.

${ }^{102}$ PSZRI (I), t. 5, nr 3006, s. 410-411.
} 
stępcy za złamanie litery prawa i odseparowaniu go od reszty społeczeństwa ${ }^{103}$. Chodziło o odstraszenie pozostałych mieszkańców kraju od podejmowania działań niezgodnych z ustawami, co stanowiło środek prewencyjny i wychowawczy. Dlatego zaproponowany w Artykule Wojskowym asortyment kar prowadził do okrutnych kaźni, odbywających się w miejscach publicznych z udziałem setek osób. Zdaniem Piotra I najskuteczniejszą metodą egzekwowania prawa była kara śmierci, jak dawniej dzielona na zwyczajną i kwalifikowaną. Tę pierwszą, w postaci odcięcia głowy, powieszenia i arkebuzowania (rozstrzelania) stosowano wyłącznie w odniesieniu do zbrodni natury wojskowej. Do kategorii kwalifikowanych rodzajów najwyższego wymiaru kary zasądzonych za dopuszczenie się najpoważniejszych przestępstw legislator zakwalifikował: ćwiartowanie, łamanie kołem, spalenie na stosie, wbicie na pal oraz zalanie gardła roztopionym metalem. Szersze rozpowszechnienie zyskały sankcje powodujące okaleczenie ciała, znane z poprzednich kodeksów. Chłosta przy pomocy knuta, batogów, szpicrut, rózeg i bata nie uzyskała jednak reglamentacji ilościowej. Dlatego jej praktyczne stosowanie kończyło się zazwyczaj śmiercią delikwenta. Z drugiej strony w ustawodawstwie pojawily się bardziej cywilizowane formy wymierzania sprawiedliwości. Mowa o - znanych już z Krótkiego ujęcia procesów... - zsyłce na katorgę, zamknięciu w więzieniu i degradacji służbowej, jak również nieznanych jeszcze w rosyjskim prawodawstwie śmierci politycznej i publicznym pokajaniu się ${ }^{104}$. Ich pojawienie się - jak skonkludował W. Martynow - wynikało z zaszczepienia przez Piotra I w systemie sądownictwa prawideł podsądności stanowej i osobistej, co z kolei oznaczało przyznanie wyższym i wykształconym stanom społecznym przywilejów honorowych ${ }^{105}$. Tym samym Artykuł Wojskowy naruszał zasadę równości wszystkich obywateli wobec prawa. Coraz częściej wymierzana przez sądy sankcja osadzenia w więzieniu dzieliła się na prostą i ciężką. Tej ostatniej towarzyszyło zakucie w kajdany. W przypadku zesłania, delikwenci trafiali w pierwszej kolejności na Syberię albo do miast leżących na peryferiach kraju. Roboty katorżnicze - uprzednio niepraktykowane - należały do jednych z najbardziej bolesnych środków represyjnych. Doniosłe miejsce zajmowały kary majątkowe w rodzaju konfiskaty dobytku, grzywny na rzecz skarbu państwa i osób prywatnych oraz potrąceń z żołdu. Ustawodawca dopuszczał całkowity i częściowy przepadek mienia, z tym że ten pierwszy kriegsrechty stosowały równolegle do zawyrokowania kary śmierci i zsyłki. Ponadto sędziowie sięgali do takiego środka, jak pokuta cerkiewna ${ }^{106}$.

\footnotetext{
103 Ibidem, s. 320-322.

104 Ibidem, s. 320-382.

105 W. Martynow, op.cit., s. 166.

106 PSZRI (I), t. 5, nr 3006, s. 320-382.
} 
Wczytując się w Artykut Wojskowy można dojść do przekonania, że legislator przewidział w nim odpowiedzialność praktycznie za każdy rodzaj czynu niezgodnego z prawem, jakiego mogli dopuścić się oficerowie, podoficerowie i szeregowcy w czasie konfliktu zbrojnego i w okresie pokoju. $\mathrm{Z}$ tego względu w akcie tym ustalono sankcje za takie przestępstwa wojskowe i ogólnopaństwowe, jak zabójstwa, gwałty, kradzieże, różnego rodzaju uszkodzenie ciała czy nawet paranie się czarami albo trwanie w pogaństwie. W przeciwieństwie do Krótkiego ujęcia procesów... zestaw kar nie został jednak wyszczególniony w jednej części, a konkretne środki represyjne prawodawca przypisał do odpowiednich zbrodni oraz wykroczeń, opisanych w 209 artykułach, pogrupowanych w 24 rozdziały. D. Sierow podkreślił fakt sformułowania rozmaitych odmian zdrady, uznanej za najcięższe przestępstwo w siłach zbrojnych, któremu nie poświęcono zbyt wiele miejsca we wcześniejszym materiale prawodawczym. Równocześnie zwrócił uwagę na brak informacji o przestępstwach służbowych, jakich mogliby się dopuścić urzędnicy wojskowi, jak również zupełne pominięcie kwestii karalności łapownictwa ${ }^{107}$. Za zabieg innowacyjny, jeśli chodzi o technikę prawną, należy uznać zamieszczenie w omawianej regulacji komentarzy do 70 artykułów. $Z$ jednej strony zawierały one wykładnię poszczególnych norm i zalecenia co do ich stosowania podczas procesów sądowych, $\mathrm{z}$ drugiej zaś uzupełniały lub uściślały istniejące przepisy. W maju 1716 r. - jak ustalił P.O. Bobrowskij - sprecyzowano zapis przewidujący odpowiedzialność oficerów i żołnierzy za uczestnictwo w przemocy, grabieży i niszczeniu mienia ludności cywilnej ${ }^{108}$. Następnego roku, w dekrecie z 20 grudnia, nastąpiło złagodzenie sankcji za dezercję ${ }^{109}$. Jak widać, Artykut Wojskowy podlegał uzupełnieniom w drodze publikowania w kolejnych latach odrębnych dekretów. Generalnie stanowił ogromny krok naprzód - przynajmniej w porównaniu z Ułożeniem Szeremietjewa i Krótkim Artykutem - na płaszczyźnie armijnego ustawodawstwa karnego, będąc regulacją bardziej precyzyjną i odpowiedniejszą do praktycznego wykorzystania przez sądowe instytucje orzekające. Niezależnie od tego, nie udało się opracować jednego zwartego dokumentu kodyfikującego normy dyscyplinarne, bowiem nadal obowiązywało wiele rozmaitych aktów prawnych z tej dziedziny.

Oczywiście podejmowano próby uporządkowania wojskowego materiału prawodawczego, czego rezultatem było wydanie drukiem w 1839 r. Regulaminu wojskowo-karnego. W jego pierwszej części legislator zdefiniował przestępstwo jako czyn zabroniony przez wojskowe ustawy karne i zagrożony stosowną sankcją. Oprócz tego przeprowadzono kategoryzację działań łamiących prawo na

107 D.O. Sierow, Wojenno-ugołownoje..., s. 170.

108 P.O. Bobrowskij, Wojennyje zakony Pietra Wielikogo w rukopisjach i pierwopieczatnych izdanijach, Sankt- Pietierburg 1887, s. 66-67.

${ }^{109}$ PSZRI (I), t. 5, nr 3136, s. 528. 
przestępstwa powszechne i wojskowe, zbrodnie dokonane w czasie wojny i pokoju, jak również przestępstwa karne oraz wykroczenia dyscyplinarne. Pojawił się ponadto podział czynów naruszających ustawy na umyślne, niezamierzone i przypadkowe. Novum stanowiło wyszczególnienie poszczególnych stadiów czynów karalnych na zamysł, zamach i zbrodnię dokonaną. Ustawodawca przewidział także instytucję współudziału, zaliczając do grona wspólników winowajcy podżegaczy, pomocników, ukrywających oraz uczestników. Co interesujące, zachowując instytucję decymacji, do prawodawstwa wprowadzono specjalną formę współudziału w przestępstwach dokonanych przez całe formacje wojskowe ${ }^{110}$.

Wykaz środków represyjnych przewidzianych w Regulaminie wojskowo-karnym obejmował: 1) karę śmierci; 2) pozbawienie lub ograniczenie wolności przez: zesłanie na katorgę, osiedlenie w odległych guberniach, skierowanie do rot aresztanckich, osadzenie w twierdzy, areszt w odwachu, służbę wojskową w randze szeregowca; 3) pozbawienie praw poprzez: śmierć polityczną lub cywilną, odebranie wszystkich praw stanu, spoliczkowanie, odebranie szlachectwa, orderów, odznaczeń i patentów, dymisję ze służby, wysłanie na przymusowy urlop, błaganie poszkodowanego o przebaczenie, przeniesienie do innej jednostki, całkowite usunięcie z sił zbrojnych; 4) kary cielesne za pomocą: piętnowania, przepędzenia przez szereg i bicia szpicrutami (w odniesieniu do żołnierzy armijnych oddziałów regularnych), chłosta knutem i batem (stosowana wyłącznie wobec kozaków); 5) sankcje cerkiewne: pokuta, okazanie skruchy, napomnienie i odmowa chrześcijańskiego pochówku ${ }^{111}$. Legislator zmienił podejście do najwyższego wymiaru kary. Podczas gdy w Artykule Wojskowym była ona karą główną, to teraz stała się środkiem wyjątkowym, stosowanym jedynie podczas wojny. W czasie pokoju do kary śmierci sądy mogły sięgać zaledwie w trzech wypadkach: 1) dokonania przestępstwa państwowego rozpatrywanego przez Najwyższy Sąd Karny; 2) czynu karalnego wiążącego się ze złamaniem przepisów kwarantanny oraz 3) ucieczki do górali kaukaskich i Turcji. W pozostałych sprawach z udziałem oficerów oraz niższych rang niepodlegającym prawnie karom cielesnym, sankcję pozbawienia życia składy orzekające zastępowały pozbawieniem oskarżonych wszystkich praw stanu i zesłaniem na katorgę na Sybir. Jeśli na ławie oskarżonych zasiadali podoficerowie i szeregowcy niekorzystający z przywilejów stanowych, to kriegsrechty zamiast kary śmierci zasądzały: chłostę szpicrutami, wykluczenie ze służby wojskowej i zsyłkę na katorgę ${ }^{112}$. Nastąpiła więc humanizacja polityki karnej, która

110 SWM, t. 12, cz. 2, k. 1, s. 176.

111 Ibidem, s. 175-176.

112 Ja.N. Jermołowicz, ,, Sobranije ocziszczennych, priwiedionnych w porjadok i jasnost'dopotniennych $i$ wo mnogom isprawliennych, no... prieżnich ugołownych naszych zakonow". Razwitije wojenno-ugołownogo zakonodatiel'stwa w pierwoj połowinije XIX wieka (1812-1867 gg.), Wojenno-istoriczeskij żurnal" 2015, nr 4, s. 11-17. 
rozpoczęła się w zasadzie już za panowania Elżbiety Piotrowny. Stanowiło to pochodną tak popularyzacji w społeczeństwie ideologii oświeceniowej, jak i coraz częstszego korzystania przez sądy z kar pozbawienia skazanych wolności, czyli ich osadzania w więzieniach, odwachach i twierdzach. Jednak w ujęciu ogólnym cele środków represyjnych pozostały takie jak dawniej, bowiem nadal ich przewodnia myśl koncentrowała się wokół odwetu na przestępcy oraz odstraszeniu i ostrzeżeniu potencjalnych sprawców. Nadrzędną intencją ustawodawcy było wykluczenie z armii winnych zbrodni, toteż środek ten towarzyszył większości orzeczeń końcowych wydawanych przez kriegsrechty. Największe rozpowszechnienie zyskały w ciągu pierwszej połowy XIX w. kary cielesne orzekane wobec podoficerów i szeregowców oraz degradacja w stosunku do oficerów.

Pomimo wyraźnego postępu cywilizacyjnego w przedmiocie polityki penitencjarnej Regulamin wojskowo-karny zawierał wiele istotnych mankamentów. Należały do nich: samowola w wymierzaniu kar, nieproporcjonalność zasądzonych sankcji do wagi dokonanego czynu przestępczego, brak wyraźnego rozgraniczenia pomiędzy dyscyplinarnymi a karnymi środkami represyjnymi oraz częste ingerowanie w prawną i faktyczną treść sankcji karnej. W rezultacie na katorgę, stanowiącą jedną z cięższych kar, skazywano w armii bez wyroku sądowego, w trybie dyscyplinarnym. Przy zasądzeniu sankcji przepędzenia przez szereg, bardzo popularnej w rosyjskich siłach zbrojnych, dowolnie określano liczbę uderzeń, co kończyło się $\mathrm{z}$ reguły śmiercią skazanego ${ }^{113}$. Niezależnie od kilku postępowych modyfikacji, widocznych przede wszystkim w złagodzeniu dotychczas stosowanych sankcji, Regulamin wojskowo-karny stanowił syntezę przerobionych norm zawartych w Artykule Wojskowym z przepisami wydanymi w latach następnych, które legislator starał się powiązać w spójny system prawny. Dlatego był to kodeks przestarzały, choć już pozbawiony wielu obcych naleciałości i poszerzony o własne rozwiązania z dziedziny materialnego prawodawstwa karno-procesowego.

Podsumowując, aparat sprawiedliwości lądowych sił zbrojnych Rosji w XVIII i pierwszej połowie XIX w. opierał się na orzecznictwie kriegsrechtów, mających charakter tymczasowych komisji wojskowo-sądowych. Nie były one samodzielnymi organami orzekającymi, albowiem ferowane przez nie wyroki zatwierdzali albo głównodowodzący armiami, korpusami i dywizjami, albo wyższe organa administracyjne (Kolegium Wojny, departament audytorski Ministerstwa Wojny) i sądownicze (Audytoriat Generalny), jak i sam cesarz. Przewód sądowy w kriegsrechtach prowadzono w oparciu o zasady procesu inkwizycyjnego, które pozbawiały podsądnego prawa do obrony, zaś sędziów uprawnienia do wzywania świadków. Dlatego fundament w orzecznictwie stanowiły zeznania pisemne, złożone w toku śledztwa, które również nie były pro-

${ }^{113} S W M$, t. 12 , cz. 2, k. 1, s. 179-180. 
wadzone w sposób zadowalający. Ze znacznie bardziej cywilizowanych form procesowych korzystały w czasie wojny sądy polowe, choć rola naczelników wojskowych pozostawała w ich przypadku nadal bardzo duża. Ponieważ w sądach wojskowych zasiadali oficerowie liniowi, przeważnie nieobeznani z niuansami procedur sądowych oraz ustawodawstwem karno-procesowym, to nadrzędna rola w orzecznictwie wojskowym należała do audytorów.

\section{POCZĄTKI ROSYJSKICH SŁUŻBY AUDYTORSKICH}

Oblicze carskich instytucji odpowiedzialnych za prowadzenie audytu w armii lądowej kształtowało się - podobnie jak całego systemu wojskowego wymiaru sprawiedliwości - na przestrzeni wielu dziesięcioleci. Po raz pierwszy wspomniał o nich w swym Regulaminie Wojskowym generał Adam Weide. Proponował on umieszczenie przy wyższym sądzie wojskowym generała audytora, mającego z jednej strony występować w roli strażnika praworządności w czasie rozpraw sądowych, a z drugiej naczelnika kancelarii tzw. dumy wojskowej, stanowiącej rodzaj wyższego organu doradczego w siłach zbrojnych. Generał audytor powinien być człowiekiem prawdomównym, rozsądnym i wykształconym, a nade wszystko obeznanym z prawodawstwem wojskowym ${ }^{114}$.

Sporządzony przez generała Weide dokument nie zyskał mocy prawnej, ale propozycje w nim zawarte zostały przyjęte i rozwinięte w późniejszym ustawodawstwie wojskowym. Regulamin Minionych Lat już znacznie bardziej szczegółowo precyzował zakres obowiązków audytorów. Ich zadaniem w sądach pułkowych było nadzorowanie przestrzegania prawa oraz prawidłowego stosowania ustaw. Ponadto do ich powinności należało przyjmowanie przysięgi od asesorów, podpisywanie dokumentów w imieniu niepiśmiennych asesorów, prowadzenie ksiąg sądowych, sporządzanie końcowych wyroków, jak również ich odczytywanie po zatwierdzeniu przez prezesów składów orzekających. Przy sądzie generalnym miał z kolei funkcjonować, na prawach jego członka, generał audytor. Chociaż jego obowiązki pokrywały się z tymi, jakie stanowiły domenę audytorów pułkowych, to dodatkowo musiał on realizować ogólny nadzór nad procesem wykonywania władzy sądowniczej, wprowadzać w życie orzeczenia sądów pułkowych i sądu generalnego, ogłaszać w oddziałach wojskowych dekrety carskie, rejestrować niektóre akta notarialne, dozorować i wydalać z sił zbrojnych wszystkie osoby postronne, przesłuchiwać i ewidencjonować jeńców, rozstrzygać spory pomiędzy żołnierzami a właścicielami szynków i kupcami

114 Woinskij ustaw Wiejdie 1698 g., Sankt-Pietierburg 1841, s. 67. 
(łącznie z wydawaniem wyroków w tego typu sprawach), określać wysokość cen na wszelkiego rodzaju towary dostarczane armii oraz rozpoczynać przewody sądowe w wypadku nieobecności oskarżyciela w sądzie generalnym. $\mathrm{W}$ razie jakichkolwiek trudności wiążących się z interpretacją i stosowaniem ustaw audytorzy pułkowi mogli zgłaszać się do generała audytora z prośbami o pomoc ${ }^{115}$. Jak stwierdził M. Akiszin, generał audytor dysponował wszystkimi pełnomocnictwami uzyskanymi od audytorów pułkowych i w razie potrzeby mógł z nich korzystać w sądzie generalnym ${ }^{116}$.

Regulamin Minionych Lat, podobnie jak Nakaz Wojskowy lub Artykuty Wojskowe Weidego, oparty na zachodnioeuropejskich rozwiązaniach prawnych, miał charakter regulacji tymczasowej. Rozbudowa sił zbrojnych na płaszczyźnie taktycznej i administracyjnej wymagała dalszego rozwoju ustawodawstwa wojskowego w postaci rozmaitych ukazów, instrukcji, artykułów i punktów, opartych już nie tylko na obcych zapożyczeniach, ale również własnych doświadczeniach. Do tej grupy regulacji należał Krótki Artykut, zawierający między innymi normy z dziedziny prawa karnego i procesowego. Dokument ten wspominał również o organizacji sądownictwa wojskowego. Przy sądach pułkowych należało powoływać audytorów, zaś przy sądzie generalnym - generała audytora. Urzędnicy ci przyjmowali przysięgę od wszystkich sędziów i odczytywali przepisy potrzebne do rozstrzygnięcia sprawy. Jeśli okazały się one niewystarczające, to audytorzy mieli obowiązek doboru dodatkowych regulacji prawnych. Po zakończeniu obrad sądu zbierali głosy oddane przez sędziów, zaczynając od oficerów najwyższych rangą ${ }^{117}$. Rozwiązania zawarte w Krótkim Artykule zostały wykorzystane w późniejszym prawodawstwie wojskowym.

Ważną cezurą w procesie organizacji i rozwoju instytucji audytoriatu w Cesarstwie Rosyjskim był 19 lutego 1711 r., kiedy ukazał się wykaz etatów dla jednostek kawalerii i piechoty ${ }^{118}$. Zgodnie $\mathrm{z}$ nim w ramach lądowych sił zbrojnych należało wyznaczyć trzech generałów audytorów, trzech generałów lejtnantów audytorów, dwunastu audytorów brygadowych, po jednym audytorze w pułkach kawalerii (w sumie 33) i pułkach piechoty (łącznie 42), jak również po jednym audytorze w pułkach garnizonowych. Zatem zamierzano powołać do służby 105 audytorów (w tym 31 cudzoziemców), pobierających rokrocznie uposażenie w ogólnej wysokości 16770 rubli. Natomiast formacje artylerii - stosownie

115 Ustaw Prieżnich Liet, s. 10-11.

116 M.O. Akiszin, U istokow juridiczeskoj profiessii w Rossii: wojennyje auditory Pietra Wielikogo, „Lienigradskij juridiczeskij żurnał” 2009, nr 2, s. 119.

117 Artikut Kratkij, s. 70-71, 73.

118 PSZRI (I), t. 4, nr 2519, s. 590-614. 
do etatu z 8 lutego 1712 r. - otrzymały tylko jednego audytora z roczną pensją 180 rubli $^{119}$.

Status prawny służb audytorskich zyskał trwałe podstawy w Krótkim ujęciu procesów lub spraw sądowych. Ponieważ stanowiska prezesów i asesorów pełnili w kriegsrechtach generalnych i pułkowych wyłącznie oficerowie liniowi, przeważnie nieposiadający odpowiedniej wiedzy prawniczej, to zabiegiem koniecznym stawało się mianowanie przy sądach audytorów, po raz pierwszy uznanych za specjalnych urzędników, określonych w ustawie jako ,element prawniczy w sądzie wojskowym". Krótkie ujęcie procesów... wprowadzało podział na oberaudytorów oraz audytorów generalnych i pułkowych, domagając się wyznaczania na te stanowiska osób z dobrą znajomością prawa. W czasie śledztwa, a zwłaszcza podczas rozprawy, audytor był zobowiązany do przygotowania stosownej dokumentacji prawniczej i wcześniej zebranego materiału dowodowego potrzebnych do wydania wyroku. Jednocześnie przesłuchiwał on oskarżonego oraz świadków, jak również pomagał asesorom w rozwiązywaniu wszelkiego rodzaju problemów natury prawnej, jakie wyniknęły w czasie procesu, udzielając im stosownych rad i wyjaśnień. Koniec końców, urzędnik ten zbierał głosy wszystkich członków składu orzekającego, sporządzając na ich podstawie werdykt końcowy wraz z uzasadnieniem, który następnie ogłaszał. Co ciekawe, audytorzy nie mieli prawa głosu podczas debaty nad sentencją, czyli ustawa nie uznawała ich za członków sądu. Niemniej jednak w razie stwierdzenia jakichkolwiek uchybień proceduralnych, w postaci nadużywania lub pogwałcenia prawa przez prezesa lub asesorów, audytor miał obowiązek poinformowania o nich całego składu orzekającego. Jeśli kriegsrecht negatywnie ustosunkował się do tego rodzaju wątpliwości, to musiał umotywować swą decyzję. Zatem ustawodawca nałożył na audytorów obowiązek nadzorowania procesu przestrzegania prawa przez sądy, podobnie zresztą jak i trybu przekazywania spraw do odpowiednich instancji. Pełniąc swe obowiązki w toku procesu sądowego - zgodnie z zamysłem legislatora - audytorzy powinni cieszyć się pełną niezależnością od jakichkolwiek organów i urzędników. Niestety nie przewidziano w tym względzie żadnych gwarancji natury prawnej. Tymczasem wszyscy audytorzy, bez względu na rangę, podlegali dowódcom wojskowym, którzy - stosownie do litery Krótkiego ujęcia procesów ... - pełnili funkcje przewodniczących kriegsrechtów generalnych i pułkowych. Innymi słowy, po zakończeniu procesu audytorzy mogli podlegać prześladowaniom z ich strony ${ }^{120}$.

Istotne uzupełnienia w stosunku do nakreślonego w Krótkim ujęciu procesów... statusu prawnego służb audytorskich wprowadzał Regulamin Wojskowy z 1716. Na czele kancelarii wojskowej, uznawanej za poprzedniczkę Kolegium

\footnotetext{
119 PSZRI (I), t. 4, nr 2480, s. 792.

${ }^{120}$ PSZRI (I), t. 5, nr 3006, s. 383, 385, 387-388, 408; M.O. Akiszin, op.cit., s. 119-121.
} 
Wojny, stanął teraz generał audytor posiadający pełnomocnictwa do sądzenia wszystkich przestępstw, niezależnie od tego, kto się ich dopuścił. Prawodawca zaznaczył, że urzędnik ten oprócz dobrej znajomości prawa, powinien być człowiekiem ,zacnego sumienia”. W przypadku choroby lub nadmiaru obowiązków do pomocy generałowi audytorowi wyznaczono generała audytora lejtnanta oraz kilku oberaudytorów. Tych ostatnich wraz z generałem audytorem ustawa uznała za wyższych dowódców armijnych. Natomiast audytorów pułkowych, odpowiadających randze kapitana, zaliczono do grona pracowników sztabu ${ }^{121}$.

Tymczasem 3 czerwca 1719 r. na podstawie ukazu imiennego cara powołano w ramach kancelarii, a potem Kolegium Wojny, wydział audytorski funkcjonujący od 1763 r. jako Ekspedycja Audytorska ${ }^{122}$. W skład tego organu weszli: generał audytor, generał fiskał, oberaudytor oraz po dwóch kopistów i kancelistów. Wydział audytorski zawiadywał sprawami biurowymi całego pionu sądowego lądowych sił zbrojnych, gromadząc wyciągi z orzeczeń kriegsrechtów wymagane do przeprowadzenia rewizji spraw, jak również prowadząc rejestr wszystkich spraw sądowych, w których stroną byli oficerowie. Za jego pośrednictwem wyroki trafiały do ostatecznego zatwierdzenia przez Kolegium Wojny i cesarza.

Działania legislacyjne podjęte w następnych latach przez Piotra I wpłynęły na obniżenie dotychczasowej, stosunkowo wysokiej pozycji audytorów w siłach lądowych, których działalność w armii koncentrowała się - podobnie jak fiskałów - na zadaniach natury kontrolnej i sądowo-śledczej ${ }^{123}$. Etat armijny z 9 lutego 1720 r. oraz Tabela o rangach z 24 stycznia 1722 r. znacznie obniżyły ich status służbowy, o czym dokładniej będzie mowa poniżej. Ogólny upadek prestiżu profesji audytorskiej - zdaniem N. Pietuchowa - można wythumaczyć przede wszystkim drugorzędnością zagadnień prawnych w armii w pierwszej ćwierci XVIII w., niską skutecznością działalności audytorów, co wynikało ze słabej znajomości ustawodawstwa wojskowego i ich zależności służbowej od przełożonych oraz pojawieniem się w armii w $1722 \mathrm{r}$. instytucji prokuratury ${ }^{124}$. Co więcej, stosownie do litery regulaminów wojskowych audytorów pułkowych obarczono powinnościami natury logistycznej, co nie pozwalało im całkowicie skoncentrować się na obowiązkach wiążących się ściśle z wykonywaniem władzy sądowniczej. Praca $\mathrm{w}$ intendenturze, uznawana $\mathrm{w}$ korpusie oficerskim za niegodną oficera i szlachcica, skutecznie odstraszała ewentualnych kandydatów do pracy na rzecz wymiaru sprawiedliwości ${ }^{125}$.

${ }^{121} \operatorname{PSZRI}(\mathrm{I})$, t. 5, nr 3006, s. 235, 256.

122 PSZRI (I), t. 5, nr 3383, s. 712-713.

123 P.P. Baranow, A.A. Szaposznikow, Auditory i fiskaty epochi Pietra Wielikogo: Zarożdienije rossijskich institutow finansowogo kontrolja, „Finansy i kriedit” 2016, t. 22, s. 31.

${ }_{124}$ N.A. Pietuchow, op.cit., s. 39.

125 SWM, t. 12, cz. 2, k. 1, s. 105. 
Po śmierci cara-reformatora służby audytorskie zlikwidowano, choć w latach następnych kilkakrotnie je przywracano. Niemniej dzięki zabiegom Piotra I uzyskały one na wiele lat trwałą organizację systemową. Najwyższe stanowiska zajmowali trzej generałowie audytorzy, z tym że jeden z nich znajdował się przy Kolegium Wojny, natomiast dwaj pozostali przy armiach. Ich pomocników tytułowano generałami audytorami lejtnantami. Oberaudytorów i audytorów w brygadach, dywizjach i pułkach mianowano w Kolegium Wojny. Podlegali oni bezpośrednio dowódcom związków taktycznych i pułków, przy których pełnili służbę ${ }^{126}$. Niezależnie od tego instytucja audytoriatu borykała się z wieloma bolączkami, z których największą były braki kadrowe o odpowiednim poziomie przygotowania prawniczego.

\section{POWSTANIE I EWOLUCJA RESORTOWYCH INSTYTUCJI AUDYTORSKICH SZCZEBLA CENTRALNEGO}

Brak wyspecjalizowanych organów prawnych w lądowych siłach zbrojnych okazał się na tyle dotkliwy, że 24 stycznia 1797 r. Paweł I wydał ukaz, na mocy którego przy Kolegium Wojny powołano do życia Audytoriat Generalny. Przekazano mu wszystkie sprawy, jakimi dotychczas zajmowała się Ekspedycja Audytorska, formalnie zlikwidowana siedem dni później. Ustawodawca nadał Audytoriatowi Generalnemu status najwyższego sądu wojskowego w formacjach lejb-gwardii (dotychczas posiadały własnego oberaudytora), armii lądowej i flocie, tak w odniesieniu do spraw cywilnych, jak i karnych. Na czele tej instytucji stanął generał audytor, mający do dyspozycji: dwóch oberaudytorów, registratora i kancelistę ${ }^{127}$. Równolegle do Audytoriatu Generalnego działało utworzone 9 stycznia 1797 r. tzw. Audytorstwo Generalne, instytucja posiadająca charakter kancelarii specjalnej przy osobie imperatora. Jego zadanie polegało głównie na rozpatrywaniu pisemnych wniosków, odnoszących się do spraw śledczych prowadzonych przeciwko oficerom, podoficerom i szeregowcom wywodzącym się ze stanu szlacheckiego, jak również przygotowywaniu wyroków sądowych do zatwierdzenia przez monarchę. Faktycznie jednak rzeczona kancelaria albo nigdy nie rozpoczęła pracy, albo - co bardziej prawdopodobne - stała się składową częścią powołanego 15 dni później Audytoriatu Generalnego, który przejął w całości jej obowiąz$\mathrm{ki}^{128}$. Do powinności tego ostatniego należało, obok wymienionych już działań, powoływanie komisji śledczych mających rozpatrywać sprawy osób oddanych

\footnotetext{
126 PSZRI (I), t. 6, nr 3890, s. 486-490; t. XLIII: kniga sztatow, cz. 1, s. 15-38.

${ }_{127}$ PSZRI (I), t. 24, nr 17 775, s. 312-313; nr 17757, s. 301.

${ }^{128}$ PSZRI (I), t. 24, nr 17719, s. 270; W.F. Nowicki, A.W. von Szwarc, G.K. Szul'c (red.), Wojennaja enciktopiedija, t. 3, Sankt-Pietierburg 1911, s. 252-253.
} 
pod sąd wojskowy przez najwyższe instytucje państwowe oraz prowadzenie korespondencji w kwestii konfirmowania wyroków sądowych przez cara. Oprócz tego Audytoriat Generalny zobligowano do ponaglania składów orzekających, aby w miarę możliwości jak najszybciej doprowadzały prowadzone sprawy do końca, jak również udzielania komisjom śledczym i kriegschrechtom fachowych porad i pomocy w razie gdyby napotkały jakiekolwiek trudności proceduralne czy prawne. Niezależnie od Audytoriatu Generalnego kompetencje w zakresie wykonywania sądownictwa nadal posiadało Kolegium Wojny ${ }^{129}$. Na mocy ukazu z 18 czerwca 1799 r. Audytoriatowi Generalnemu podporządkowano wszystkich audytorów pełniących służbę $\mathrm{w}$ armii ${ }^{130}$. Od tej pory do rzeczonego organu należało ich wyznaczanie, zwalnianie, awansowanie, nagradzanie i przenoszenie na inne stanowiska służbowe. Zatem w 1799 r. w rosyjskich siłach zbrojnych pojawił się resort wojskowo-sądowy, nazywany również audytorskim ${ }^{131}$.

Wynikiem zmian organizacyjnych na poziomie centralnym była rozbudowa struktur audytorskich na szczeblu pułków. Ukaz z 4 kwietnia 1798 r. nakazywał, aby przy każdym garnizonie znajdował się jeden audytor ${ }^{132}$. Jeśli było ich więcej, to należało uznawać ich albo za audytorów miejskich, albo zaliczać do etatu Audytoriatu Generalnego, z tym że powinni oni pełnić obowiązki w pułkach. Konieczność dysponowania przez formacje garnizonowe (nawet te, składające się $\mathrm{z}$ więcej niż jednego batalionu) własnymi audytorami i dodatkowo płatnikami (skarbnikami) władze potwierdziły w dekrecie z 2 lutego 1802 r. stwierdzając, że gdyby nie udało się powołać audytora, to jego obowiązki miał pełnić płatnik ${ }^{133}$. Stosowanie takich rozwiązań świadczyło o problemach kadrowych w pionie sądowniczym, z jakimi siły zbrojne borykały się w zasadzie od początku XVIII w. Co więcej - jak zaznaczyła A. Kurabcewa - nie zawsze można było uznać pracę służb audytorskich za efektywną ${ }^{134}$. Ogólnie rzecz biorąc, za panowania Pawła I wykształciła się hierarchia audytorów, która niewiele się zmieniła do $1867 \mathrm{r}$. Prezentowała się ona następująco: generał audytor, jego pomocnicy (zastępcy) oberaudytorzy, audytorzy rozrzuceni po pułkach i tzw. audytoriatach miejskich oraz ci bezpośrednio oddelegowani ponad etat do Audytoriatu Generalnego.

Trudności z obsadą wakatów audytorskich w pułkach legły u podstaw decyzji o kolejnych przeobrażeniach strukturalnych $\mathrm{w}$ audytoriacie na najwyższym szczeblu. Na mocy ukazu z 8 września 1805 r. nadano Audytoriatowi General-

${ }^{129}$ PSZRI (I), t. 26, nr 19440; SWM, t. 12, cz. 2, k. 1, s. 6.

${ }^{130} \operatorname{PSZRI}(\mathrm{I}), \mathrm{t} .25, \mathrm{nr} 19023$, s. 693.

${ }_{131} S W M$, t. 12, cz. 2, k. 1, s. 6-7.

132 PSZRI (I), t. 25, nr 18465, s. 179.

${ }_{133}$ PSZRI (I), t. 27, nr 20215, s. 88.

134 A.P. Kurabcewa, Wozniknowienije i diejatiel'nost'instituta wojennogo auditoriata $w$ XVIII-XIX ww., „Forum Prawa” 2013, nr 1, s. 550. 
nemu status kolegium ${ }^{135}$. Tym samym instytucja ta ponosiła odpowiedzialność tylko przed cesarzem i Senatem, uzyskując de facto samodzielność resortową. Na jej czele stanął, w charakterze przewodniczącego, generał audytor. Podlegało mu czterech generałów lejtnantów lub generałów majorów (dwóch spośród nich pochodziło z sił lądowych, a dwóch służyło we flocie) oraz dwóch radców wojskowych zajmujących stanowiska członków i asesorów. Sprawy biurowe znajdowały się w gestii generała audytora lejtnanta, mającego do dyspozycji sześciu oberaudytorów; czterech spośród nich zajmowało się zagadnieniami armii, zaś dwóch nadzorowało marynarkę i admiralicję. Generał audytor lejtnant jako dyrektor kancelarii Audytoriatu Generalnego kontrolował wszystkich jego pracowników oraz czuwał nad prawidłowym trybem prowadzenia spraw sądowych i śledczych, w tym głównie nad terminowym oraz dokładnym przygotowywaniem wyciągów z akt, które wraz z innymi dokumentami poświadczał własnoręcznym podpisem. Oberaudytorzy natomiast sprawowali pieczę nad aktami spraw, jakie napływały z niższych instancji sądowych. Przy każdym z nich funkcjonowało po dwóch audytorów oraz dodatkowo jeden oberaudytor, pełniący obowiązki sekretarza, któremu do pomocy przydzielono jednego specjalnego audytora. Ustawodawca zastrzegał, że wszyscy audytorzy powinni odznaczać się biegłością w znajomości prawa. W Audytoriacie Generalnym pracowali także egzekutor i archiwariusz wraz z pomocnikiem, sprawujący pieczę nad całą dokumentacją urzędu. Z kolei prowadzenie korespondencji i szkolenie personelu należało do pracowników kancelaryjnych. Generała audytora mianował car, podobnie jak pozostałych audytorów, ale nominacja na poszczególne stanowiska i wszelkie awanse służbowe następowały w przypadku tych ostatnich na wniosek przewodniczącego, czyli generała audytora. Tylko egzekutor, archiwariusz i kanceliści byli wyznaczani przez generała audytora ${ }^{136}$. Na utrzymanie całego personelu Audytoriatu Generalnego (w tym również: lekarza, kurierów i stróża) oraz wydatki wiążące się z zakupem materiałów biurowych i świec państwo asygnowało łącznie 41700 rubli rocznie ${ }^{137}$.

Najważniejszą powinnością Audytoriatu Generalnego stało się przeprowadzanie rewizji i ostateczne rozstrzyganie spraw prowadzonych przez sądy wojskowe w stosunku do wszystkich oficerów, podoficerów i szeregowców pełniących służbę w armii lądowej i marynarce wojennej. Jak wiadomo, rewizja to procedura polegająca na przeglądzie (audycie) przez wyższą instancję sprawy karnej i wydanego wyroku pod kątem zgodności z obowiązującymi ustawami, w celu tak potwierdzenia niewinności oskarżonego, jak również zrozumienia istoty popełnionego

\footnotetext{
${ }^{135}$ PSZRI (I), t. 28, nr 21904, s. 1214-1221.

${ }^{136}$ Ibidem, s. 1218-1219.

${ }^{137}$ PSZRI (I), t. 43: kniga sztatow, cz. 2, s. 154.
} 
przestępstwa lub zdemaskowania jego prawdziwego sprawcy ${ }^{138}$. Jeśli w sprawie zostały stwierdzone uchybienia proceduralne bądź nieścisłości, to Audytoriat Generalny albo odsyłał akta z powrotem do sądu wojskowego w celu wniesienia stosownych poprawek, uzupełnień i wyjaśnień, albo sam je rozpatrywał posiłkując się odpowiednimi przepisami. To ostatnie rozwiązanie stosowano także $\mathrm{w}$ razie wpłynięcia skargi na wyrok sądu, uznany przez oskarżonego za zbyt wysoki lub niezgodny z prawem. W takim przypadku Audytoriat Generalny musiał jednak wyjaśnić, na czym polegały niedopatrzenia lub błędy. Jeśli sąd przeprowadził rozprawę prawidłowo, zgodnie z obowiązującym ustawodawstwem, to generał audytor lejtnant przekazywał akta sprawy oberaudytorowi, który sporządzał z nich stosowny wyciąg. Audytoriat Generalny miał nieco ponad trzy godziny na rozpatrzenie i uzyskanie konsensusu w sprawach wnoszonych do rewizji. Tylko w stosunku do ważnych i obszernych spraw termin ten wydłużano do następnego dnia, ale nigdy nie dłużej. Orzeczenia końcowe Audytoriatu Generalnego uznawano za ostateczne jedynie w wypadku rewizji spraw, w których stroną byli podoficerowie i szeregowcy niepochodzący ze szlachty (wcześniej znajdowały się one w gestii Kolegiów Wojny i Admiralicji). Odesłanie akt, stosownie do przynależności podsądnego, albo do Kolegium wojny albo Kolegium Admiralicji, oznaczało uprawomocnienie wyroku. Natomiast werdykty, jakie zapadły w stosunku do generałów i oficerów pochodzenia szlacheckiego, były odsyłane do imperatora w celu ich usankcjonowania. Potem akta trafiały z powrotem do Audytoriatu, gdzie podlegały archiwizacji; wcześniej wykonywano z nich kopię, odsyłaną do resortu wojny lub admiralicji, zgodnie z przynależnością oskarżonego, informując o tym kancelarię cesarską. Koniec końców, wyżsi dowódcy w wojskach lądowych i flocie mogli kierować do Audytoriatu Generalnego wszelkiego rodzaju sprawy dotyczące oficerów, z którymi sami nie mogli sobie poradzić. Oprócz prowadzenia rewizji spraw karnych, do obowiązków rzeczonego organu należała kontrola terminowości prac kriegsrechtów. Dlatego co miesiąc wszystkie komendy wojsk lądowych, floty, ordonans-hauzy (zarządy komendanckie w miastach) i poszczególne komisje musiały przysyłać do niego tzw. „statiejnyje spiski”, czyli dokumenty zawierające podstawowe dane o oskarżonych. W razie zwłoki Audytoriat Generalny miał prawo ponaglać wszystkie powyższe instytucje ${ }^{139}$.

Ukaz z 8 września 1805 r. szczegółowo precyzował również tryb prowadzenia spraw śledczych i sądowych przez sądy wojskowe. Do powinności generała audytora należało zatwierdzanie wyroków śmierci w stosunku do oskarżonych

138 I.S. Dikariew, op.cit., s. 61.

139 PSZRI (I), t. 28, nr 21904, s. 1219-1221; SWM, t. 12, cz. 2, k. 1, s. 36. Po utworzeniu 8 września 1802 r. Ministerstwa Sił Wojskowo-Lądowych i Ministerstwa Sił Wojenno-Morskich Kolegia Wojny (wraz z ekspedycjami) i Admiralicji stały się ich składowymi częściami; zob. Wysszije i central'nyje..., s. 35, 197. 
pochodzenia nieszlacheckiego; we wszystkich pozostałych przypadkach sankcjonowali je inspektorzy wojskowi i naczelnicy floty. Audytoriat Generalny musiał być informowany - w drodze wydania dekretu cesarskiego - o każdym wypadku oddania pod sąd ober- i sztabsoficera (do stopnia podpułkownika włącznie). Kiedy zapadła decyzja o potrzebie osądzenia pułkownika lub generała, a imperator nie powołał składu orzekającego, Audytoriat Generalny miał obowiązek - po uprzednim skontaktowaniu się z dowództwem armii bądź marynarki wojennej - przedstawić carowi kandydatury przewodniczącego i członków sądu. Werdykt zasądzony przez ten ostatni trafiał następnie do Audytoriatu Generalnego, który przeprowadzał jego rewizję $e^{140}$.

Ogólnie rzecz ujmując, po 1805 r. funkcje służb audytorskich zostały znacząco poszerzone w porównaniu do obowiązków nakreślonych w styczniu 1797 r. Ich centralnym ogniwem stał się teraz Audytoriat Generalny, w którego rękach skoncentrowano sprawozdawczość oraz nadzór na całym pionem sądowym resortów wojskowego i morskiego. W efekcie do Audytoriatu Generalnego zaczęto kierować wszystkie sprawy śledcze i sądowe prowadzone dotychczas w Kolegiach Wojny i Admiralicji, w tym także te odnoszące się do podoficerów i szeregowców gwardii ${ }^{141}$. Od 1808 r. Audytoriat rozpatrywał również sprawy o degradację wszystkich wojskowych do rangi szeregowego ${ }^{142}$.

Następne miesiące przyniosły nieznaczne zmiany w systemie organizacyjnym niektórych agend audytorskich, co wiązało się z potrzebą zsynchronizowania ich pracy z Audytoriatem Generalnym. Od 1 kwietnia 1808 r. przy głównodowodzących armiami zainstalowano po jednym generale audytorze lejtnancie oraz oberaudytorze. Przy dowódcach korpusów pojawił się oberaudytor, posiadający dodatkowo do pomocy audytora. Do naczelników dywizji oddelegowano natomiast po jednym oberaudytorze ${ }^{143}$.

Proces stopniowego pomniejszania znaczenia Audytoriatu Generalnego rozpoczął się w 1808 r. w związku z zabiegami podjętymi przez nowego ministra wojny Aleksego Arakczejewa. Nie chcąc pogodzić się z faktem istnienia w armii niezależnej od niego struktury postarał się on o uzyskanie wyłącznego prawa do składania cesarzowi raportów odnoszących się do pracy pionu sądowego w siłach zbrojnych. Ponadto od 1808 r. Audytoriat Generalny zobligowano do kierowania

${ }^{140}$ PSZRI (I), t. 28, nr 21904, s. 1216-1218.

${ }^{141}$ Od października 1805 r. rządy gubernialne, czyli ciała kolegialne powoływane przy gubernatorach, zobligowano do kierowania wszystkich skarg na: podoficerów, szeregowców i niższych urzędników wojsk lądowych do Audytoriatu Generalnego, a nie jak dotychczas do Kolegium Wojny; zob. PSZRI (I), t. 28, nr 21944, s. 1286.

${ }_{142} S W M$, t. 12, cz. 2, k. 1, s. 7.

143 PSZRI (I), t. 30, nr 22939 s. 164. 
wszystkich próśb o przebaczenie win, nie do monarchy, ale właśnie do ministra wojny ${ }^{144}$.

Niezależnie od działalności Arakczejewa, dalsze przeobrażenia w systemie strukturalnym instytucji audytorskich wiązały się ściśle z przeobrażeniami organizacyjnymi Ministerstwa Sił Wojskowo-Lądowych (od 17 grudnia 1815 r. noszącego nazwę Ministerstwo Wojny), jakie nastąpiły 27 stycznia 1812 r. ${ }^{145}$ Stosownie do wydanego w tym dniu ukazu zarząd pionem sądowym w armii miał odtąd należeć do obowiązków ministra wojny oraz departamentu audytorskiego. Ten ostatni, oprócz rady ministerialnej, kancelarii ogólnej i specjalnej oraz pięciu innych departamentów, stał się składową częścią nowo utworzonego resortu. Każdy departament dzielił się na wydziały, które składały się z referatów. Pieczę nad departamentami sprawowali dyrektorzy podporządkowani ministrowi wojny ${ }^{146}$. Dyrektora departamentu audytorskiego nazywano generałem audytorem. Miał on do dyspozycji zastępcę oraz dwóch radców wojskowych. Naczelników wydziałów tytułowano oberaudytorami, natomiast szefów referatów audytorami. Zatem kancelaria departamentu liczyła łącznie trzech oberaudytorów, piastujących stanowiska naczelników wydziałów oraz sześciu audytorów kierujących pracami referatów. Wszyscy audytorzy, podobnie jak egzekutor, posiadali zastępców. W archiwum służbę pełnili naczelnik referatu z zastępcą oraz archiwariusz $^{147}$. Departament audytorski łączył w sobie trzy wydziały. Pierwszy posiadał dwa referaty. Sprawy kadrowe, takie jak mianowanie, zwalnianie, nagradzanie i karanie personelu urzędniczego należało do obowiązków pierwszego referatu. Drugi zaś zajmował się rewizjami i wydawaniem wyroków w szczególnie ważnych sprawach sądowych oraz śledczych, w tym także tych z udziałem generałów i pułkowników, które nadsyłały komisje działające przy pułkach oraz ordonans-hauzach. Do wydziału drugiego, składającego się również z dwóch referatów, należały rewizje spraw mniejszej wagi. Jego pierwszy referat przeprowadzał rewizje spraw, w których stroną byli sztabsoficerowie, zaś do drugiego należały audyty spraw odnoszących się do oberoficerów i podoficerów wywodzących się ze stanu szlacheckiego. Pierwszy referat wydziału trzeciego powołano w celu gromadzenia i ochrony wszystkich ustaw i rozporządzeń dotykających funkcjonowania pionu sądowego w siłach zbrojnych. Z kolei drugi referat kontrolował składy orzekające, aby nie spowalniały tempa rozpraw. Oprócz tego wydawał też dla nich instrukcje, jeśli pojawiły się jakieś trudności proceduralne oraz weryfikował wykazy aresztantów wojskowych ponoszących odpowiedzialność sądową ${ }^{148}$.

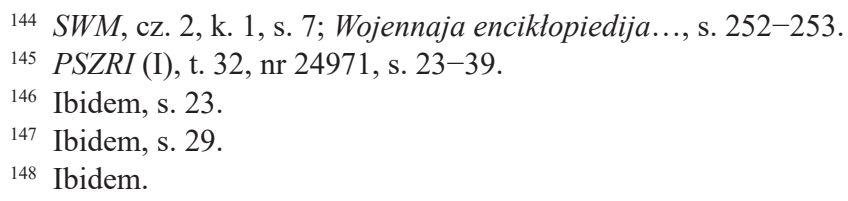


Pomimo przekształcenia Audytoriatu Generalnego w departament ministerialny, nadal funkcjonował on w oparciu o przepisy zawarte w ukazie z 8 września 1805 r. Niemniej we wspomnianym już dekrecie z 27 stycznia 1812 r. ustawodawca pominął wiele zapisów określających zakres prerogatyw służb audytorskich. Wystarczy wymienić chociażby: 1) wskazówki odnoszące się do powoływania składów orzekających do spraw osób oddanych pod sąd na podstawie rozkazów cesarskich; 2) prowadzenie korespondencji na temat wykonywania wyroków konfirmowanych przez imperatora; 3 ) rozpatrywanie spraw o degradację wojskowych do rangi szeregowca, czy w końcu 4) rewizje spraw z udziałem skazanych na karę śmierci podoficerów i szeregowców niepochodzących ze szlachty. Jednocześnie niektóre kategorie spraw znajdujące się uprzednio w gestii Audytoriatu Generalnego przekazano teraz departamentowi inspektorskiemu ${ }^{149}$.

Następstwem wyżej opisanych modyfikacji była faktyczna likwidacja Audytoriatu Generalnego (nie wydano jednak w tym względzie żadnego oficjalnego rozporządzenia) i podział jego dotychczasowych obowiązków pomiędzy departamenty działające w ramach resortów wojskowego i morskiego. Oznaczało to utratę przez wojskowy pion sądowy samodzielności uzyskanej w 1805 r. i oparcie jego organizacji na podstawach biurokratycznych. Generałów audytorów jako szefów departamentów ministerialnych w pełni podporządkowano ministrom armii i floty. Nadal mogli oni samodzielnie zatwierdzać wyroki sądowe, nie licząc się z opiniami swoich doradców, chociaż ustawy dopuszczały możliwość rozstrzygania spraw w trybie kolegialnym. Oczywiście departamenty audytorskie pełniły jednocześnie rolę tak wyższych sądów wojskowych, jak i centralnych organów administracyjnych zawiadujących organizacją i pracą działów sądowych w lądowych siłach zbrojnych i marynarce wojennej. Ustawy nie oddzielały bowiem od siebie tych dwóch płaszczyzn działalności służb audytorskich ${ }^{150}$. Niezależnie od faktu pozbawienia Audytoriatu Generalnego dotychczasowej samodzielności jako wyższej instancji sądowej i faktycznego przekształcenia go w składową część Ministerstwa Wojny, wzmocnienie uprawnień administracyjnych tego organu zaowocowało uporządkowaniem armijnego pionu sądowego oraz jego większym zespoleniem z całościową strukturą organizacyjną lądowych siłach zbrojnych.

Pomniejszenie uprawnień agend audytorskich $w$ armii na szczeblu centralnym wiązało się także z następstwami wojny z napoleońską Francją. Po zakończeniu działań wojennych przeprowadzono w Rosji całościową reorganizację lądowych sił zbrojnych, które w myśl ukazu z 28 października $1814 \mathrm{r}$. zostały podzielone na dwie Armie (1. i 2.) oraz kilka samodzielnych korpusów ${ }^{151}$. Jak już wyżej za-

\footnotetext{
${ }^{149} S W M$, t. 12 , cz. 2, k. 1, s. 13-14.

${ }^{150}$ Ibidem, s. 14-16.

151 PSZRI (I), t. 32, nr 25723, s. 1077.
} 
znaczono, ich dowódcy uzyskali prawo do ostatecznego zatwierdzania i wykonywania w okresie wojny i pokoju wyroków sądowych wydanych w stosunku do wszystkich żołnierzy i podoficerów stanu szlacheckiego, jak również oficerów (do rangi pułkownika włącznie), jeśli nie przewidywały one kary śmierci bądź pozbawienia stopnia wojskowego. Wszystkie tego rodzaju orzeczenia - w myśl dekretu z 12 grudnia 1815 r. - należało następnie odsyłać do departamentu audytorskiego. Ten ostatni powinien również otrzymywać do rewizji sprawy prowadzone przeciwko generałom $\mathrm{w}$ jednostkach podporządkowanych głównodowodzącym Armiami (1. i 2.). W stosunku do formacji, które nie były częściami składowymi rzeczonych dwóch armii, jak i samodzielnych korpusów, w pełni utrzymano zwierzchnią władzę sądową departamentu audytorskiego ${ }^{152}$. Nastąpił więc podział najwyższych kompetencji sądowniczych pomiędzy głównodowodzących armiami oraz samodzielnymi korpusami a departamentem audytorskim, z wyraźnym obniżeniem pozycji tego ostatniego organu.

Kolejne zmiany na płaszczyźnie uprawnień nadrzędnych instytucji audytorskich stanowiły pochodną reform przeprowadzonych na poziomie najwyższych struktur dowódczych. Aleksander I niezadowolony z ich działalności podczas kampanii z lat 1812-1814 zdecydował się na wyodrębnienie w centralnym zarządzie wojsk dwóch pionów: polowego i gospodarczego. Pierwszy podporządkowano szefowi Sztabu Głównego, powierzając dotychczasowe departamenty inspektorski i audytorski pieczy generała dyżurnego. W myśl opublikowanego 7 lutego 1816 r. dekretu „O utworzeniu Dyżurstwa Sztabu Głównego Jego Imperatorskiej Wysokości" obowiązki departamentu audytorskiego uległy pewnemu poszerzeniu, w porównaniu do wachlarza jego zadań sprecyzowanych w $1812 \mathrm{r}$. Od tej chwili powinien on dodatkowo: 1) prowadzić korespondencję w kwestii wykonywania zatwierdzonych przez cesarza wyroków sądowych oraz usankcjonowanych przez niego opinii głównodowodzących armiami i korpusami w sprawach sądowych, jak również decyzji służb audytorskich; 2) rozpatrywać wnioski o degradację wojskowych (na podstawie orzeczeń sądowych oraz bez nich), którzy zasługiwali na złagodzenie wyroku; 3) usuwać z wykazów przebiegu służby informacje o odpowiedzialności sądowej tych urzędników, którzy po procesie

${ }^{152}$ PSZRI (I), t. 33, nr 26021, s. 403404. W bezpośredniej łączności z ukazem z 12 grudnia 1815 r. były dekrety z: 8 czerwca 1816 r., 16 lutego 1818 r. i 4 sierpnia 1819 r., przyznające ministrowi wojny, generałowi-inspektorowi pionu inżynieryjnego i inspektorowi artylerii, jak również generałowi-feldcechmajstrowi prawo do samodzielnego prowadzenia (bądź kierowania do sądu) i zatwierdzania werdyktów końcowych w sprawach podległych im oficerów i urzędników do stopnia pułkownika (lub równorzędnego w stosunku do urzędników wojskowych), jeśli nie został zasądzony wyrok śmierci albo pozbawienia stopnia; zob. PSZRI (I), t. 33, nr 26021, s. 403-404; nr 26300, s. 877-878; t. 36, nr 27910, s. 324. O regulacjach tych wspominają autorzy wydawnictwa Stolietije Wojennogo Ministierstwa, podając jednak błędne daty wydania dwóch z nich, mianowicie: 8 lipca (a nie 8 czerwca) 1816 r. oraz 18 (zamiast) 16 lutego 1818 r; zob. SWM, t. 12, cz. 2, k. 1, s. 131. 
okazali się niewinni; 3) posiadać zapieczętowany wykaz z nazwiskami urzędników oddanych pod sąd na podstawie rozkazu carskiego lub z mocy władzy nadanej głównodowodzącym armiami i korpusami oraz sporządzać miesięczne spisy osób ponoszących odpowiedzialność sądową, stosownie do podziału jednostek pomiędzy: armie, korpusy i dywizje ${ }^{153}$. Z drugiej strony departament audytorski nie posiadał prawa do ostatecznego wyrokowania w sprawach: 1) generałów, sztabs- i oberoficerów oraz niższych rang korzystających ze specjalnych praw stanu, jeśli za popełnione przestępstwa podlegali utracie tych praw; 2) podoficerów i szeregowców odznaczonych orderem św. Anny oraz Pruskim Krzyżem Żelaznym, gdy wyrok przewidywał ich odebranie oraz 3) grup ponad dziewięciu wojskowych skazanych za wspólne popełnienie tego samego czynu karalnego. We wszystkich tych przypadkach prawo do zatwierdzenia werdyktu miał wyłącznie imperator. Generalnie rzecz ujmując, w odniesieniu do niektórych kategorii spraw wyroki departamentu audytorskiego stanowiące efekt przeprowadzonego audytu były ostateczne, i jako takie uzyskiwały moc prawną. Innym razem miały charakter opinii (tzw. „wniosków’ bądź „orzeczeń’), zaś sama rewizja stanowiła jedynie zabieg wstępny, przed końcową konfirmacją wyroku przez cesarza ${ }^{154}$.

Niezależnie od obowiązków bezpośrednio związanych z jurysdykcją, departament audytorski bez przerwy realizował zadania w charakterze centralnego organu administracyjnego do spraw sądownictwa wojskowego. Należały do nich: 1) nadzór nad działalnością sądów i audytorów; 2) wpływanie na składy orzekające, aby jak najszybciej doprowadzały sprawy do końca; 3) udzielanie sędziom wyjaśnień w celu prawidłowego stosowania ustaw; 4) gromadzenie i przechowywanie materiału prawodawczego; 5) zaopatrywanie sądów w niezbędne regulacje prawne i w końcu 6) kontrola całego personelu pracującego w wojskowym pionie sądowym. Do tego dochodziła jeszcze weryfikacja orzecznictwa wyższych naczelników wojskowych w kierunku jego ujednolicenia, gdyż nakładanie przez nich różnych sankcji karnych za takie samo przestępstwo powodowało bałagan, dezintegrujący pracę wymiaru sprawiedliwości. Nie zawsze udawało się to osiągnąć, ponieważ nie wszystkie tego typu przypadki docierały do departamentu. Ponadto w ustawodawstwie brakowało klarownych zasad wyznaczania przez feldmarszałków i generałów kar zastępczych ${ }^{155}$.

Powołanie do życia Dyżurstwa Sztabu Głównego pociągnęło za sobą redukcję wydziałów departamentu audytorskiego do zaledwie jednego, co stanowiło efekt zmniejszenia się jego obowiązków ${ }^{156}$. Jak wiadomo od 12 grudnia $1815 \mathrm{r}$.

\footnotetext{
153 PSZRI (I), t. 38, nr 26129, s. 482.

${ }^{154} S W M$, t. 12 , cz. 2, k. 1, s. 42-43.

155 Ibidem, s. 94, 132.

156 PSZRI (I), t. 38, nr 26129, s. 482.
} 
głównodowodzący armii zachowali w czasie pokoju prawo do ostatecznego rozstrzygania spraw prowadzonych przeciwko wszystkim podległym im szarżom, $\mathrm{z}$ wyją̧tkiem generałów. Szerokie prerogatywy w kwestii sankcjonowania orzeczeń sądów wojskowych uzyskali ponadto inni wyżsi dowódcy stojący na czele formacji i instytucji, w tym nawet naczelnicy zawiadujący instytucjami, które nie były integralną częścią Armii 1. i 2 . Nadanie uprawnień sądowych wyższym dowództwom niektórych związków taktycznych, zamiast wpłynąć na zmniejszenie ilości spraw napływających do departamentu audytorskiego w celu przeprowadzenia ich rewizji, doprowadziło do zjawiska odwrotnego. Ponieważ naczelnicy wojskowi nie mieli prawa do konfirmacji wyroków śmierci ferowanych przez kriegsrechty, to musieli odsyłać sprawy do Dyżurstwa Sztabu Głównego. Wojskowe składy orzekające bardzo często stosowały najwyższy wymiar kary, co w połączeniu z dużą liczebnością armii wpływało na nadmierne przeciążenie pracą departamentu audytorskiego. Sytuację dodatkowo komplikował fakt braku nowych etatów. Niemniej czynniki rządowe zdecydowały się na podjęcie pewnych działań mających na celu usprawnienie organizacji rzeczonego departamentu, po to, aby przyspieszyć proces rozpatrywania spraw. Wszystkich pracowników zobligowano do ścisłego przestrzegania czasu pracy (od godziny 8 do 14 oraz po przerwie obiadowej od 18 do 21). Opracowano również grafik zajęć. Rezultatem tych posunięć był spadek liczby nierozstrzygniętych kazusów ${ }^{157}$.

Regulacje przyjęte w lutym 1816 r. w odniesieniu do organizacji i zakresu uprawnień służb audytorskich przetrwały w niezmienionym kształcie do 1 maja 1832 r. W tym dniu miała miejsce kolejna reorganizacja Ministerstwa Wojny, której efektem była reaktywacja Audytoriatu Generalnego. Obok Rady Wojennej i Sztabu Głównego stał się on trzecim elementem najwyższego ogniwa zawiadującego pracami Ministerstwa Wojny ${ }^{158}$. Szczegółowe przepisy reglamentujące zasady funkcjonowania Audytoriatu Generalnego ukazały się 6 czerwca, chociaż już w „Najwyżej zatwierdzonym projekcie utworzenia Ministerstwa Wojny" z 1 maja ustawodawca wspomniał, że stał się on w pewnym sensie podobny do Senatu. Minister wojny zajął wobec generała audytora taką samą pozycję, jak minister sprawiedliwości w stosunku do Senatu. Sam generał audytor natomiast upodobnił się pod względem kompetencji do oberprokuratora. Bezpośrednią konsekwencją przywrócenia Audytoriatu Generalnego, który zastąpił dotychczasowy departament audytorski Sztabu Głównego, była likwidacja Audytoriatu Sztabu Głównego do Spraw Osadnictwa Wojskowego oraz wydziału sądowego przy kancelarii ministra wojny ${ }^{159}$.

157 SWM, t. 12, cz. 2, k. 1, s. 25-26.

${ }_{158}$ PSZRI (II), t. 7, nr 5318, s. 225-226; A.S. Janczew, Auditoriat w strukturie wojennogo wiedomstwa, „Wiestnik Czieljabinskogo gosudarstwiennogo uniwiersitieta” 2012, nr 27, s. 130.

159 PSZRI (II), t. 7, nr 5318, s. 237; SWM, t. 12, cz. 2, k. 1, s. 148. Audytoriat Sztabu Głównego do Spraw Osadnictwa Wojskowego powstał 25 października 1830 r. Składał się z urzędu i kancela- 
Do obowiązków Audytoriatu Generalnego należało teraz przeprowadzanie audytu wszystkich spraw sądowych i śledczych, z tym że w roli najwyższej i ostatecznej instancji rewizyjnej występował on tylko w stosunku do spraw, w których podsądnymi byli podoficerowie i szeregowcy niewywodzący się ze stanu szlacheckiego. We wszystkich pozostałych sprawach po dokonaniu rewizji opinie Audytoriatu Generalnego za pośrednictwem ministra wojny musiały być usankcjonowane przez cesarza. Generałowi audytorowi przyznano prawo do oprotestowania stanowiska większości składu orzekającego; w takim wypadku był zobowiązany przedstawić ministrowi wojny stosowny raport. Jeśli podjęta przez ministra próba pogodzenia członków Audytoriatu Generalnego okazała się bezowocna, wnosił on do cara prośbę o zatwierdzenie końcowego werdyktu. Wszystkie wyroki zapadły kwalifikowaną większością głosów. Prawodawca podkreślił, że podczas rozpraw Audytoriat Generalny powinien kierować się prawem, nie osłabiając jego mocy. W stosunku do czynów przestępczych mniejszej wagi sugerowano sędziom łagodzenie surowości głównych kodeksów wojskowych (Artykułu Wojskowego), przy uwzględnieniu najnowszych regulacji. Po dokładnym zbadaniu okoliczności sprawy (motywów obwinionego, następstw jego działań itp.), uwzględniając przebieg służby i zasługi podsądnego, dopuszczano możliwość wnoszenia wniosków do monarchy o zastosowanie prawa łaski. Audytoriat Generalny był urzędem kolegialnym, grupującym w swym składzie mianowanych przez cara przewodniczącego i członków w rangach generalskich. Ustawa nie precyzowała liczby tych ostatnich, zastrzegając jedynie, że do rozpoczęcia prac sądu wymagana była obecność trzech członków. Organem wykonawczym i przygotowawczym Audytoriatu Generalnego stał się departament audytorski Ministerstwa Wojny, podlegający generałowi audytorowi na prawach dyrektora ${ }^{160}$.

Ustawy z 1832 r. zachowały moc tylko przez cztery lata. Dwudziestego dziewiątego marca 1836 r. opublikowano nowe założenia dla Ministerstwa Wojny ${ }^{161}$. Wprowadzały on istotne zmiany w kwestii zadań stawianych służbom audytorskim. Audytoriat Generalny obarczono powinnością stałego doskonalenia wojskowego ustawodawstwa sądowego, natomiast na barki departamentu audytorskiego spadała kontrola nad prawidłowością śledztw, ale tylko tych prowadzonych wobec generałów podlegających bezpośrednio ministrowi wojny bądź pełniących służbę w samodzielnych korpusach. W pełni potwierdzono status Audytoriatu Generalnego jako wyższej sądowej instancji rewizyjnej, z tym że legislator na

rii, w której obowiązki pełniło 2 oberaudytorów, 4 audytorów i 5 pisarzy. Pomiędzy dwa wydziały kancelarii rozdzielono postępowania rewizyjne w sprawach sądowych i śledczych prowadzonych w odniesieniu do konkretnych jednostek wchodzących w skład osiedli wojskowych; zob. PSZRI (II), t. 5, odt. 2, nr 4028, s. 208-209.

${ }_{160}$ PSZRI (II), t. 7, nr 5417, s. 368-370.

161 PSZRI (II), t. 11, odt. 1, nr 9038, s.247-347. 
płaszczyźnie prawa do przeprowadzania audytu oraz konfirmacji wyroków sądowych dokonał ścisłego rozgraniczenia pomiędzy nim a departamentem audytorskim. Przez ten ostatni - z zupełnym pominięciem Audytoriatu Generalnego - przechodziły wyroki wydane przez głównodowodzących armiami i dowódców samodzielnych korpusów, które trafiały do ostatecznego usankcjonowania przez imperatora. Wszystkie pozostałe sprawy sądowe miały być kierowane do Audytoriatu Generalnego. Mógł on zatwierdzić wyrok sądu niższej instancji, zmienić go (jeśli okazał się nieprawidłowy, w znaczeniu zbyt zaniżonej bądź zawyżonej sankcji) albo skierować sprawę do ponownego rozpatrzenia (gdy nastąpiło naruszenie form i obyczajów sądowych) ${ }^{162}$. Zatem, cytując autorów Stolietija Wojennogo Ministierstwa:

Tym sposobem prawo pomijało milczeniem kwestię odnoszącą się do niestosowności wyroku do istoty sprawy, ale jest rzeczą niewątpliwą, że sama idea trybu rewizyjnego oraz szerokie uprawnienia Audytoriatu Generalnego wprowadzały zasadę skontrolowania opinii niższej instancji o winie lub niewinności ${ }^{163}$.

Audytoriatowi Generalnemu przyznano prawo do ostatecznej konfirmacji wyroków w sprawach niższych rang tak wywodzących się ze szlachty, jak i nienależących do tego stanu, z wyjątkiem wypadków, w których zatwierdzenie należało do wyłącznych prerogatyw cara. Do tej ostatniej kategorii odnosily się sprawy: 1) generałów, sztabs- i oberoficerów oraz podoficerów i szeregowców, którym groziło pozbawienia szlachectwa lub odznaczeń wojskowych (w tym orderu św. Anny); 2) członków różnego rodzaju sekt religijnych i tych, którzy odstąpili od religii prawosławnej; 3) osób oskarżonych o obrazę majestatu; 4) przestępstw zbiorowych, w których sądzono ponad dziewięć osób za popełnienie tego samego czynu karalnego oraz 5) skazanych na karę szpicrut w wymiarze większym od przewidzianej prawem. Do zadań Audytoriatu Generalnego należało także debatowanie na projektami ustaw wojskowych, jak i interpretacji oraz uzupełnień obowiązujących regulacji. Jednocześnie obarczono go obowiązkiem dopilnowania, aby podsądni zawsze posiadali prawo do obrony i możliwość dowiedzenia swej niewinności ${ }^{164}$. Natomiast powinności departamentu audytorskiego koncentrowały się - oprócz tych omówionych powyżej - na prowadzeniu spraw biurowych w odniesieniu do całego pionu sądowego w lądowych siłach zbrojnych. Departament składał się z kancelarii, archiwum oraz czterech wydziałów. Pierwszy, nazywany zarządzającym, zajmował się wdrażaniem zatwierdzonych przez imperatora werdyktów sądowych oraz wszystkimi zagadnieniami dotyczącymi degradacji, pozbawienia odznaczeń oraz nakładania i uchylania kar dyscyplinarnych. Trzy

\footnotetext{
162 Ibidem, s. 298-301, 312.

163 SWM, t. 12, cz. 2, k. 1, s. 150.

${ }^{164}$ PSZRI (II), t. 11, odt. 1, nr 9038, s. 325-326.
} 
pozostałe wydziały, tak zwane sądowe, prowadziły z kolei sprawy: generałów, oficerów i urzędników wojskowych ${ }^{165}$.

Następne lata, głównie z powodu niezmienności tak ustawodawstwa, jak i całego systemu sądowego w armii, nie przyniosły żadnych aktów prawnych odnoszących się bezpośrednio do funkcjonowania Audytoriatu Generalnego. Zatem instytucja ta reaktywowana w oparciu o dekrety z lat 1832 i 1836 utrzymała do 1867 r. rangę wojskowej instancji rewizyjnej wyższego szczebla, choć w przedmiocie uprawnień do audytu i konfirmacji orzeczeń sądowych prawodawca dokonał ścisłego rozgraniczenia uprawnień pomiędzy nią a departamentem audytorskim.

\section{ROZBUDOWA I DZIAŁALNOŚĆ AGEND AUDYTORSKICH NA POZIOMIE ZWIĄZKÓW TAKTYCZNO-OPERACYJNYCH}

Efektem intensywnych przygotowań do starcia militarnego z Napoleonem i jego sojusznikami stało się opracowanie tzw. Zarządzeń w zakresie dowodzenia Wielka Armia Czynna sygnowanych przez Aleksandra I 27 stycznia 1812 r. Na mocy tej regulacji ustanowiono Audytoriat Polowy mający spełniać rolę wyższej instancji sądowej dla armii, ale tylko w czasie wojny. Po ustaniu działań wojennych struktura ta powinna zostać zlikwidowana, po wcześniejszym przekazaniu wszystkich prowadzonych spraw do departamentu audytorskiego Ministerstwa Wojny. Audytoriat Polowy składał się z trzech członków, spośród których najstarszy w randze generała lejtnanta pełnił funkcję przewodniczącego (prezesa); dwaj pozostali byli generałami majorami. Przewodniczącego mógł zastępować głównodowodzący armią, jeśli rozpatrywano przypadek prawny szczególnej wagi lub kiedy oskarżony posiadał wysoki stopień wojskowy. Najważniejsze zadanie Audytoriatu Polowego oscylowało wokół wyznaczania członków do sądów pułkowych, ogólny nadzór nad ich działalnością pod kątem zgodności ich działań z obowiązującymi przepisami oraz rewizje prowadzonych przez nie spraw. Audytoriaty Polowe powołano także przy dowództwach korpusów i dywizji. Ich pracami zawiadywali polowi generałowie audytorzy mający do pomocy oberaudytorów, których wyznaczano również przy korpusach oraz dywizjach; ich zastępcami byli audytorzy. Wszystkich oberaudytorów i audytorów nominował - na wniosek generała audytora - głównodowodzący armią. Członków Audytoriatu Polowego

${ }^{165}$ Ibidem, s. 269-270. Zgodnie z tymczasowym etatem departamentu audytorskiego opracowanym jeszcze 23 lutego 1833 r., utrzymanie jego personelu oraz wydatki kancelaryjne kosztowały rocznie skarb państwa 76090 rubli; zob. PSZRI (II), t. 8, odt. 2, s. 57. 
spokrewnionych (lub tylko podejrzanych o powinowactwo) z oskarżonym należało zastąpić na czas trwania procesu innymi sędziami ${ }^{166}$.

Po pokonaniu Francji lądowe siły zbrojne przeszły do stanu okresu pokojowego, ale ich pion sądowy nadal funkcjonował w oparciu o Regulamin sądownictwa polowego i Polowy kodeks karny, czyli regulacje składowe Zarzadzeń w zakresie dowodzenia Wielka Armia Czynna. Stanowiło to bezpośredni rezultat podziału 28 października 1814 r. Wielkiej Armii Czynnej na dwie Armie (1. i 2.), ale $\mathrm{z}$ utrzymaniem ich organizacji na rozwiązaniach z czasów wojny ${ }^{167}$. Zatem przy obu tych armiach działały audytoriaty polowe. Ich etaty zostały zatwierdzone w 1816 r., 19 października dla 1. Armii (działał przy niej były Audytoriat Polowy Wielkiej Armii Czynnej) i 2 grudnia w odniesieniu do 2. Armii. Każdy $\mathrm{z}$ nich posiadał $\mathrm{w}$ swych składzie generała audytora z zastępcą i oberaudytorów. Niemniej z powodu napływu do audytoriatów coraz większej ilości spraw zaistniała konieczność opracowania nowych etatów i struktur organizacyjnych. W odniesieniu do 1 . Armii nastąpiło to 4 czerwca $1823 \mathrm{r}^{168}$. Na wstępie zaznaczono, że Audytoriat Polowy stanowił w istocie część Sztabu Głównego sił zbrojnych, który w swej pracy powinien kierować się ogólnymi regulacjami prawnymi. Do jego składu przewidziano generała lejtnanta i dwóch generałów majorów, z tym że stanowisko przewodniczącego miał piastować najstarszy stopniem. W razie niemożności wyboru oficerów w takich rangach dopuszczano możliwość wyznaczenia na członków, minimum pułkowników lub podpułkowników (niższe szarże nie wchodziły w grę), a prezesem mógł zostać generał major. Pracami bieżącymi kierowała dwuwydziałowa kancelaria. Naczelnikami jej wydziałów byli oberaudytorzy. Każdy z nich posiadał do dyspozycji, w charakterze zastępców, dwóch audytorów i dodatkowo trzech pisarzy. Pierwszy wydział koncentrował się na prowadzeniu spraw sądowych i śledczych odnoszących się do wszystkich oficerów, podoficerów i szeregowców pochodzenia szlacheckiego. Zajmował się także przestępstwami popełnionymi wspólnie przez szlachetnie urodzonych posiadaczy stopni oficerskich oraz niższe rangi niewywodzące się z warstwy uprzywilejowanej. Natomiast działania drugiego wydziału odnosiły się wyłącznie do podoficerów i szeregowców niemogących się poszczycić klejnotem szlacheckim. Oprócz personelu zatrudnionego w wydziałach, w kancelarii Audytoriatu Polowego znajdował się urzędnik do przepisywania dokumentów oraz dwóch audytorów. Jeden pełnił obowiązki sekretarza, a drugi - do zleceń specjalnych - pracował przy prezesie. Mianowanie, zwalnianie, przesuwanie na inne stanowisko służbowe oraz nagradzanie generała audytora, oberaudytorów i audytorów następowało

\footnotetext{
166 PSZRI (I), t. 32, nr 24975, s. 75-78.

167 PSZRI (I), t. 32, nr 25723, s. 1077.

168 PSZRI (I), t. 38, nr 29495, s. 1022-1025.
} 
po zatwierdzeniu przez imperatora, na wniosek Audytoriatu Polowego oraz po porozumieniu się głównodowodzącego z szefem Sztabu Głównego ${ }^{169}$. Zazwyczaj faktyczna liczebność pracowników Audytoriatu Polowego 1. Armii w poszczególnych latach nieco odbiegała od stanów etatowych. Rosyjskie źródła urzędowe podają, że pomiędzy pierwsza połową lat 40 -tych XIX w. a 1874 r. pełnili w nim służbę: jeden przewodniczący, jeden polowy generał audytor, jeden - trzech członków (z reguły jeden lub dwóch posiadało status pełniących obowiązki), dwóch-trzech oberaudytorów piastujących funkcję naczelników wydziałów, czterech sześciu audytorów zajmujących stanowisko zastępców naczelników wydziałów, urzędnik zarządzający sekretariatem, thumacz oraz niekiedy jeden dodatkowy urzędnik ${ }^{170}$. Liczba oberaudytorów i audytorów może sugerować zwiększenie o jeden liczby wydziałów, o czym milczą źródła i autorzy publikacji albo - co bardziej prawdopodobne świadczyć o oddelegowaniu dodatkowych urzędników w związku ze znaczną ilością nierozstrzygniętych spraw. Za tą ostatnią hipotezą przemawiają choćby informacje podane przez generała majora Wasilija Dokudowskiego, jednego z członków Audytoriatu Polowego 1. Armii. Zagadnienie to zostanie obszerniej opisane poniżej.

Zakres kompetencji Audytoriatu Polowego 1. Armii pokrywał się z prerogatywami departamentu audytorskiego z 7 lutego 1816 r., z dwoma tylko wyjątkami. Po pierwsze pozbawiono go prawa do ostatecznej rewizji spraw, w których stroną byli niepochodzący ze szlachty podoficerowie i szeregowcy, po drugie zaś - obarczono obowiązkiem odsyłania wszystkich rozstrzygniętych spraw do departamentu audytorskiego. W sumie Audytoriat Polowy, w odróżnieniu od departamentu audytorskiego, nie dysponował uprawnieniami do ostatecznego wyrokowania w żadnej sprawie. Co więcej, wszystkie wydane przez niego orzeczenia sądowe (w tym również te dotyczące niższych rang) podlegały zatwierdzeniu przez głównodowodzącego. Niezależnie od prowadzenia audytu spraw sądowych i śledczych instytucja, o której mowa, zajmowała się wydawaniem instrukcji i pouczeń sądom wojskowym powoływanym przy jednostkach 1 Armii (w przeciwieństwie do Zarządzeń... z 27 stycznia 1812 r. nie było już mowy o wyznaczaniu członków składów orzekających), jeśli te podczas śledztw i rozpraw natrafiły na jakieś trudności proceduralne. Do tego dochodziły jeszcze rozmaite powinności biurowe, mianowicie kontrola nad terminowością rozstrzygania spraw, sporządzanie wykazów prowadzonych spraw i list imiennych wszystkich pracowników Audytoriatu Polowego czy w końcu przechowywanie dokumentacji dotyczącej działalności działu sądowego ${ }^{171}$.

\footnotetext{
169 Ibidem, s. 1023.

170 Zob. źródło do tabeli 2.

${ }^{171}$ PSZRI (I), t. 38, nr 29495, s. 1023-1024.
} 
Obowiązki członków Audytoriatu Polowego, jak również tryb prowadzenia spraw, także odpowiadały rozwiązaniom przyjętym w $1816 \mathrm{r}$. w stosunku do departamentu audytorskiego. Jedyna różnica w tym względzie polegała na tym, że Audytoriat Polowy wydawał wyroki w systemie kolegialnym. Skład orzekający, po wysłuchaniu sprawozdania końcowego i skonfrontowawszy go z aktami sprawy, przedstawiał swoją opinię i w przypadku pojawienia się rozbieżności wydawał werdykt na podstawie obowiązujących ustaw, z jego zatwierdzeniem przez głównodowodzącego ${ }^{172}$.

Audytoriat Polowy 1. Armii zmieniał swą przynależność, a co za tym idzie również nazwę i terytorialny zasięg oddziaływania wraz z przeobrażeniami, jakie w poszczególnych latach następowały w całościowym systemie organizacji rosyjskich sił zbrojnych. Podczas wojny z Turcją (1828-1829) oraz powstania w Królestwie Polskim (1830-1831) rozpoczął się podział elementów składowych 1. Armii pomiędzy 2. Armię i - powołaną do życia 1 grudnia $1830 \mathrm{r}$. w związku z wydarzeniami nad Wisłą - Armię Czynną ${ }^{173}$. Ostateczne rozformowanie Sztabu Głównego 1. Armii nastąpiło 1 września 1835 r., zaś główna część jej związków taktycznych została włączona do Armii Czynnej ${ }^{174}$. Kolejne modyfikacje strukturalne wiązały się z udziałem Rosji w Wojnie Krymskiej. Maj 1855 r. przyniósł wydzielenie z Armii Czynnej tzw. Armii Środkowej przeznaczonej do walk z koalicją angielsko-francusko-turecko-sardyńską. Natomiast oddziałom pozostawionym w Kongresówce nadano nazwę Armia Zachodnia. W rezultacie w styczniu 1856 r. Sztab Główny Armii Czynnej przemianowano na Sztab Główny Armii Zachodniej i Środkowej, a w marcu tego roku z wojsk obu rzeczonych związków taktyczno-operacyjnych utworzono 1 . Armię ${ }^{175}$. Generalnie do 1830 r. oraz w latach 1856-1862 stosowano określenie Audytoriat Polowy 1. Armii, natomiast pomiędzy 1830 r. a 1856 r.: Audytoriat Polowy Armii Czynnej. Jurysdykcja tej instytucji sądowej obejmowała do chwili stłumienia insurekcji polskiej w $1831 \mathrm{r}$. tylko obszar guberni kijowskiej, a potem - aż do wybuchu kolejnego powstania w 1863 r. - całe terytorium Kongresówki oraz gubernie północno-zachodnie i południowo-zachodnie, czyli rozległe obszary rozciągające się wzdłuż Dźwiny i Dniepru ${ }^{176}$.

172 Ibidem, s. 1024-1025.

173 PSZRI (II), t. 5, nr 3768, s. 688; nr 3770, s. 689.

174 PSZRI (II), t. 10, otd. 1, nr 8355, s. 907.

175 PSZRI (II), t. 31, otd. 1, nr 30075, s. 39; I.O. Garkusz (red.), Rossijskij gosudarstwiennyj wojenno-istoriczeskij archiw. Putiewoditiel', t. 1, Moskwa 2006, s. 306-307, 301; A.M. Zajonczkowskij, Wostocznaja Wojna 1853-1856, t. 1, Sankt-Pietierburg 1908, s. 458.

176 A.A. Kiersnowskij, Istorija russkoj armii, t. 2: Ot wzjatija Pariża do pokorienija Sriedniej Azii 1814-1881, Moskwa 1993, s. 18; W. Djakow, I. Miller, Ruch rewolucyjny $w$ armii rosyjskiej a powstanie styczniowe, Wrocław-Warszawa-Kraków 1967, s. 14-16; Prikazy diejstwujszcziej armii 1844 goda; PSZRI (II), t. 5, nr 3768, s. 688; nr 3770, s. 689. 
Ponieważ Sztab 1. Armii i Armii Czynnej mieścił się stale w Warszawie, to Audytoriat Polowy jako jeden z jego pionów także tam miał swą siedzibę. Wiadomo, że w 1874 r., kiedy nastapiła likwidacja tego organu, prowadził on obrady na Nowym Świecie, pod numerem $1245 \mathrm{a}^{177}$. Pewne informacje o specyfice pracy wyższego sądu rewizyjnego w okresie trzydziestolecia poprzedzającego wydarzenia 1863 r. przekazał generał major Wasilij Dokudowskij, w okresie 18501855 jeden z jego członków (w 1850 r. oraz pomiędzy 1852 r. a 1855 r., jako pełniący obowiązki członka). Oprócz rozpatrywania spraw na miejscu, Audytoriat Polowy stale delegował urzędników w teren, przeważnie do powoływania i zawiadywania pracami komisji wojskowo-sądowych, czyli kriegsrechtów, rozpatrujących tak sprawy wojskowe, jak i prawdopodobnie niektóre cywilne. Właśnie w takim charakterze Dokudowskiego wysłano w 1850 r. do Wilna, gdzie przed trzema sądami wojskowymi odbył się proces 21 osób (zapewne cywilów) oskarżonych o popełnienie bliżej nieokreślonych przestępstw politycznych. Rok wcześniej, gdy jednostki Armii Czynnej ruszyły do walki przeciwko Węgrom, Audytoriat Polowy mianował dwóch generałów z zadaniem przeprowadzenia śledztwa i procesu przeciwko żołnierzom, którzy zbuntowali się w jednej z komend przeznaczonej do udziału w interwencji na terenie monarchii habsburskiej ${ }^{178}$. Co ciekawe, Audytoriat Polowy pozostał w Warszawie i nie zaznaczył swej obecności w ekspedycji z 1849 r. Jedynie generał audytor towarzyszył jednostkom w ich marszu na południe. $Z$ tego względu pomiędzy wyższym sądem rewizyjnym a przebywającym na Węgrzech sztabem stale kursowali kurierzy, przewożący pilne raporty wymagające podpisu głównodowodzącego ${ }^{179}$.

Jeśli chodzi o codzienne funkcjonowanie Audytoriatu Polowego, to musiał się on borykać z wieloma trudnościami, wynikającymi przede wszystkim z powolności prowadzenia śledztw i procesów. Taka sytuacja miała miejsce w $1846 \mathrm{r}$., kiedy ogromna ilość nierozstrzygniętych spraw zmusiła władze do niekonwencjonalnych działań. Powodem takiego stanu rzeczy - jak wyraził się Dokudowskij - miała być nadmierna łaskawość i drobiazgowość ówczesnego generała audytora Michaiła Biełajewa, co wyraźnie sugeruje, że po prostu był on zbyt miękki w kwestii wymierzania kar. Koniec końców, zrezygnowano z pomysłu powołania specjalnej ekspedycji, która miała przyspieszyć orzecznictwo, przystając na pomysł oddania kierownictwa nad wszystkimi śledztwami Dokudowskiemu. Niewystarczająco surowy generał audytor uzyskał natomiast pieczę nad przypadkami wymagającymi zorganizowania procesu sądowego ${ }^{180}$.

\footnotetext{
177 Pamjatnaja kniżka warszawskoj gubiernii na 1874 god, Warszawa 1874, s. 24-25.

178 W.A. Dokudowskij, Wospominanija gienierat-majora Wasilija Abramowicza Dokudowskago, Riazań 1898, s. 110-111, 124, 126.

179 Ibidem, s. 110-111.

${ }^{180}$ Ibidem, s. 100.
} 
Pamiętniki Dokudowskiego rzucają również światło na stosunki łączące Audytoriat Polowy z namiestnikiem Królestwa Polskiego i zarazem głównodowodzącym Armii Czynnej generałem feldmarszałkiem Iwanem Paskiewiczem, piastującym obie te funkcje prawnie przez 25 lat. Władza księcia warszawskiego nad wojskowym wymiarem sprawiedliwości była pod każdym względem nieograniczona. W 1843 r. bezceremonialnie rozkazał on członkom wyższego sądy rewizyjnego zmienić orzeczenie końcowe w jednej ze spraw śledczych, uznając je za niedostatecznie jasno sprecyzowane. Przy okazji zasugerował składowi orzekającemu, aby w przyszłości jego członkowie nie zwracali uwagi na opinię generała audytora Grigoriewa, ze względu na jego podeszły wiek. Opisany incydent zakończył się sporządzeniem przez audytorów nowego wyroku, już bardziej zrozumiałego dla namiestnika, który go ostatecznie zaaprobował, powstrzymując się od zbesztania sędziów ${ }^{181}$. Nieliczenie się przez Paskiewicza z decyzjami Audytoriatu Polowego ujawniło się jeszcze bardziej wyraziście w sprawie jednego z urzędników, niejakiego Krasowskiego. Jeszcze w 1832 r. zawarł on umowę na zakup i dostawę prowiantu z Galicji dla wojsk kwaterujących w Kongresówce. Z powodu niedoświadczenia i beztroski ówczesnego generała intendenta Armii Czynnej Pogodina, opiewająca na wiele tysięcy rubli transakcja zakończyła się fiaskiem, przez co państwo poniosło znaczne straty finansowe. Po trwającym wiele lat procesie sąd wojskowy skazał Krasowskiego na zapłacenie skarbowi Cesarstwa około 400 tys. rubli w asygnatach, nie wymierzając żadnych dodatkowych sankcji karnych. Audytoriat Polowy zgodził się z wyrokiem, ale zaproponował zwolnienie delikwenta ze służby. Ponieważ nieposiadający żadnego majątku ruchomego i nieruchomego Krasowski nie był w stanie uiścić tak ogromnej kwoty, to wyższy sąd rewizyjny polecił jej ściągnięcie od Pogodina, który osobiście ponosił odpowiedzialność za wybór funkcjonariusza publicznego do załatwienia kontraktu, nie kontrolując należycie jego działań. Powyższy pogląd sędziowie Audytoriatu Polowego zawarli w końcowym raporcie, który za pośrednictwem generała audytora trafił do rąk namiestnika. Ten ostatni zapoznawszy się z nim wpadł we wściekłość, uznając generała intendenta za niewinnego i oskarżając członków sądu rewizyjnego o stronniczość i wręcz spiskowanie przeciwko podsądnemu. Finał całego zajścia był łatwy do przewidzenia. Ponieważ Paskiewicz uznał, że przed wydaniem werdyktu Audytoriat Polowy powinien najpierw zasięgnąć jego opinii, to polecił sporządzić nowe orzeczenie końcowe, zabraniając wspominania komukolwiek o poprzednim wyroku, przedstawionym mu uprzednio do konfirmacji. Rzecz jasna Pogodina zwolniono z wszelkiej odpowiedzialności, obciążając skarb państwa (w domyśle mieszkańców Królestwa Polskiego) obowiązkiem uiszczenia ustalonej kary pieniężnej. Natomiast członkowie Audytoriatu Polowe-

181 Ibidem, s. 81. 
go - jak obrazowo ujął to Dokudowski - „z pokorą i potulnością podwładnych poświadczyli raport własnoręcznie" ${ }^{182}$. Wyższy sąd rewizyjny Armii Czynnej był więc całkowicie bezwolny wobec naczelnego wodza, traktującego orzeczenia organów wojskowego wymiaru sprawiedliwości w sposób instrumentalny, do czego notabene - o czym już wspomniano powyżej - miał pełne prawo.

Praktycznie nieograniczonych prerogatyw sądowych rezydujących nad Wisłą namiestników carskich, nie uszczupliły w najmniejszym stopniu kolejne modyfikacje przeprowadzone w organizacji sił zbrojnych. Na mocy opublikowanego 6 lipca 1862 r. Rozporządzenia o głównym zarządzie wojskami wchodzacymi obecnie w sktad 1. Armii struktura ta została zlikwidowana ${ }^{183}$. Należące do niej formacje wcielono do trzech okręgów wojskowych: warszawskiego, wileńskiego i kijowskiego. Najwyższą władzę cywilno-wojskową w Kongresówce uzyskał namiestnik. Jego najbliższym pomocnikiem, przede wszystkim w pionie wojskowym, został generał z tytułem „dowodzący wojskami w Królestwie Polskim”, korzystający z uprawnień dowódcy samodzielnego korpusu, ale z pewnymi ograniczeniami wymienionymi w dokumencie ${ }^{184}$.

Ustawodawca pozostawił $\mathrm{w}$ dotychczasowym kształcie wyższy sąd rewizyjny, który jednak odtąd miał nosić oficjalnie nazwę Audytoriat Polowy Wojsk w Królestwie Polskim. Zasięg jego prerogatyw sądowych obejmował wszystkie dziesięć guberni nadwiślańskich (warszawską, kaliską, kielecką, łomżyńską, lubelską, płocką, radomską, siedlecką, suwalską i piotrkowską), jak również do 12 lipca 1863 r. obszary podległe dowodzącemu siłami wileńskiego okręgu wojskowego, bowiem znalazły się one w gestii odrębnego Audytoriatu Polowego ${ }^{185}$. Jeśli chodzi o uprawnienia wyższego sądu rewizyjnego, to rozporządzenie z $1862 \mathrm{r}$. nie wprowadzało poważniejszych modyfikacji. Jak dotychczas jego najważniejszą powinnością było rozpatrywanie spraw sądowych i śledczych i odsyłanie ich do audytu i zatwierdzenia namiestnika oraz - czego uprzednio nie praktykowano - generała zawiadującego jednostkami warszawskiego okręgu wojskowego. Namiestnik konfirmował kazusy oficerów i niższych rang pochodzenia szlacheckiego, a zatem osób korzystających ze specjalnych praw stanu, uwolnionych od kar cielesnych, jeśli za popełnione czyny karalne groziła im sankcja pozbawienia stopni i przywilejów z racji urodzenia oraz wydalenie ze służby. Z kolei wyroki utraty praw stanu i zesłania na Sybir (na osiedlenie, roboty katorżnicze bądź dożywotnią służbę w rotach aresztanckich), jakie zapadły w stosunku do podoficerów i szeregowców nienależących do warstw uprzywilejowanych, zatwierdzał

\footnotetext{
182 Ibidem, s. 82.

183 PSZRI (II), t. 37, otd. 1, nr 38452, s. 660.

184 Ibidem, s. 662.

185 PSZRI (II), t. 38, nr 39862, s. 841-843.
} 
dowodzący wojskami. Dodatkowo, w orbicie kompetencji namiestnika do ostatecznej konfirmacji orzeczeń sądów wojskowych, znalazły się sprawy cywilów wywodzących się ze wszystkich stanów społecznych skazanych za popełnienie przestępstw politycznych. Naturalnie zanim trafiły one do namiestnika, podlegały one analizie Audytoriatu Polowego, co zwiększało wachlarz jego obowiązków ${ }^{186}$.

Objęcie polskiej ludności cywilnej jurysdykcją wyższego wojskowego organu sądowego stanowiło bezpośrednią konsekwencję wprowadzenia nad Wisłą, jeszcze 3 października 1861 r. stanu wojennego, który miał uspokoić kraj objęty od kilkunastu miesięcy falą demonstracji i manifestacji o charakterze narodowo-religijnym ${ }^{187}$. W oparciu o tę regulację cały obszar Kongresówki został podzielony na siedem oddziałów. Na ich czele stanęli reaktywowani (działali już w latach 1831-1858) naczelnicy wojenni, podlegający najpierw Kancelarii Specjalnej do Spraw Stanu Wojennego przy Głównodowodzącym 1. Armią i Namiestniku Królestwa, a potem Zarządowi generała-policmajstra ${ }^{188}$. Kompetencje oraz podległość służbowa naczelników wojennych, szczegółowo reglamentowane w instrukcjach opublikowanych w latach 1861-1864, wzrosły niepomiernie po wybuchu powstania styczniowego. Ogólnie rzecz ujmując, do ich powinności należała szeroko rozumiana koordynacja działań wojska, policji i organów administracji cywilnej w kierunku jak najszybszego spacyfikowania insurekcji i zaprowadzenia porządku. Władze zwierzchnie obdarzyły ich między innymi ogromnymi prerogatywami z dziedziny wymiaru sprawiedliwości. Rozkaz z 13 stycznia 1863 r. uprawniał naczelników wojennych działających w imieniu cesarza do zatwierdzania wyroków śmierci zasądzonych przez wojskowe sądy doraźne wobec powstańców schwytanych z bronią w ręku ${ }^{189}$. Tym samym naczelnicy wojenni stali się kolejną nad Wisłą - oprócz namiestnika - instytucją sądową wyższego szczebla z prawem do wyrokowania w sprawach ludności cywilnej, przez co przewyższali swymi kompetencjami Audytoriat Polowy, nieposiadający przecież prawa do konfirmacji żadnych orzeczeń końcowych ${ }^{190}$. Dwa dni po wydaniu powyższego rozkazu głów-

186 PSZRI (II), t. 37, otd. 1, nr 38452, s. 664.

187 Archiwum Główne Akt Dawnych (dalej: AGAD), III Rada Stanu Królestwa Polskiego, sygn. 15 b, s. 216 .

188 Archiwum Państwowe w Płocku, Naczelnik Wojenny Powiatu Płockiego, sygn. 1, k. 25-28v; AGAD, Zarząd Generał-Policmajstra w Królestwie Polskim [Departament II, wydział 1] (ZG-PwKP), sygn. 33, s. 352-365.

189 Archiwum Państwowe w Radomiu (dalej: APR), Zarząd Naczelnika Wojennego Oddziału Radomskiego (dalej: ZNWOR), sygn. 34, s. 11.

${ }^{190}$ Wraz z nominacją 19 października 1863 r. generała Fiodora Berga na stanowisko namiestnika i zarazem głównodowodzącego wojsk w Królestwie Polskim, ostateczna konformacja przypisanych prawnie tym dwu urzędom kategorii spraw sądowych oraz śledczych z udziałem oficerów i niższych rang należała już do jednej osoby; zob. I. Koberdowa, Wielki książę Konstanty w Warszawie 1862-1863, Warszawa 1862, s. 253. 
nodowodzący zobowiązał jednak naczelników wojennych do comiesięcznego przesyłania Audytoriatowi Polowemu, w celu ich dostarczenia do departamentu audytorskiego Ministerstwa Wojny, wykazów imiennych osób, przeciwko którym sądy polowe zakończyły rozprawy, po czym nastąpiło zatwierdzenie werdyktów. W spisach tych powinny znaleźć się informacje na temat pochodzenia społecznego skazanego, istoty czynu przestępczego, jakiego się dopuścił oraz potwierdzenie końcowego orzeczenia sądowego ${ }^{191}$. Tym sposobem na barki wyższego sądu rewizyjnego spadł obowiązek gromadzenia materiałów statystycznych o efektach działalności naczelników wojennych i przekazywania ich do centralnych instytucji audytorskich w armii.

Prerogatywy sądownicze naczelników wojennych zostały sprecyzowane 4 lutego 1863 r., gdy namiestnik nadał im prawo do konfirmacji werdyktów sądów polowych, ale tylko w stosunku do schwytanych przywódców oddziałów, emisariuszy i oficerów rosyjskich, którzy przeszli na stronę wroga ${ }^{192}$. Pozostałych, wziętych do niewoli uzbrojonych uczestników powstania, jak i tych, którym udowodniono współpracę z nimi (poprzez organizowanie dostaw broni i żywności oraz udzielanie schronienia), specjalna komisja - powołana do określenia stopnia ich winy - miała podzielić na cztery kategorie. Pierwszą stanowili posiadacze ziemscy, urzędnicy, szlachta, duchowieństwo i uznani za szczególnie niebezpiecznych dla caratu. Do drugiej włączono osoby, które dobrowolnie zgłosiły akces do rebelii lub chciały przez to uniknąć represji ze strony władz powstańczych. Trzecia grupa obejmowała przymusowo bądź podstępnie wcielonych do oddziałów partyzanckich, zaś ostatnia nieletnich, niezakwalifikowanych do pierwszej kategorii. Jeśli komisja stwierdziła wysoki stopień winy podsądnego, sprawa trafiała do sądu wojskowego, zaś akta po rozprawie naczelnicy wojenni powinni odesłać do Audytoriatu Polowego, do rewizji, wraz z własną opinią. Natomiast w razie niskiej szkodliwości czynu, delikwenta oddawano do dyspozycji naczelnika wojennego, bez procesu. Zaliczonych do drugiej grupy naczelnicy wojenni mieli kierować do armii, przekazując informacje o wszystkich niezdolnych do służby wojskowej do Audytoriatu Polowego, który sporządzał w tej sprawie raport dla namiestnika. Tych, którzy znaleźli się w trzeciej kategorii, po złożeniu przysięgi wierności, naczelnicy wojenni odstawiali pod dozorem policyjnym do stałych miejsc zamieszkania, zaś osoby z czwartej kategorii przekazywali władzom szkolnym lub rodzicom (względnie krewnym) ${ }^{193}$.

Dwudziestego czwartego maja 1863 r. Dyżurstwo Sztabu Wojsk obwieściło naczelnikom wojennym nowe zasady typizacji wszystkich uznanych za winnych

\footnotetext{
191 AGAD, ZG-PwKP, sygn. 30, s. 18.

192 APR, ZNWOR, sygn. 34, s. 72-79.

193 Ibidem.
} 
przynależności do ruchu powstańczego ${ }^{194}$. Wzorując się na rozwiązaniach zastosowanych wcześniej na obszarach wileńskiego i kijowskiego okręgów wojskowych, podzielono ich obecnie na pięć kategorii. Orzeczenia komisji wojskowo-sądowych w stosunku do winnych uczestnictwa w działalności antypaństwowej, których przyporządkowano do grupy drugiej oraz wywodzących się ze stanów uprzywilejowanych odniesionych do kategorii czwartej i piątej, naczelnicy wojenni byli zobowiązani przekazywać z własnymi opiniami do Audytoriatu Polowego. W obrębie drugiej grupy znaleźli się schwytani przez wojska cesarskie z bronią lub bez niej, którzy podburzali do wystąpień antyrządowych, a ich przynależności do rebelii nie dało się zakwestionować. Co więcej, zaliczono do niej: szlachtę, księży, lekarzy, nauczycieli, urzędników (w tym emerytowanych), oficerów w stanie spoczynku i wszystkich mogących - poprzez swoje wykształcenie i pozycję społeczną - mieć szkodliwy wpływ na naród polski. Sądy skazywały ich - odpowiednio do rangi przewinienia - albo na śmierć (w oparciu o Regulamin wojskowo-karny w edycji z 1859 r.), albo pozbawienie wszystkich praw stanu i roboty katorżnicze (na bazie Kodeksu kar głównych i poprawczych z 1845 r.), ewentualnie na osiedlenie na Syberii. Czwarta kategoria odnosiła się do osób pomagających i wspierających powstańców na wszelkie sposoby, jak i tych, którzy zataili przed władzami wojskowymi i cywilnymi miejsca koncentracji wrogich formacji oraz dyslokacji składów broni, prochu, żywności itp. Stosownie do ciężaru odpowiedzialności podlegali oni tak sankcjom stosowanym wobec należących do drugiej grupy, jak również przymusowemu poborowi wojskowemu bądź ewentualnie służbie w rotach aresztanckich resortu cywilnego. Wyjątkowo, za zgodą imperatora, naczelnicy wojenni mogli karać ich w trybie administracyjnym, mianowicie wyekspediować na osiedlenie do którejś z rosyjskich guberni wewnętrznych. Do piątej grupy zakwalifikowano wszystkich niepełnoletnich. Jeśli istniała szansa na poprawę, trafiali - za poręczeniem - pod opiekę rodziców albo krewnych. Bardziej krnąbrnych odstawiano do twierdzy w Nowogieorgijewsku, gdzie zapadała decyzja o ich dalszym losie ${ }^{195}$.

Ostatnie modyfikacje w zasadach kwalifikacji osób zaangażowanych w insurekcję Rosjanie przeprowadzili 7 marca 1865 r., utrzymując ich segregację na pięć grup $^{196}$. Stanowiło to, z jednej strony pokłosie pacyfikacji kraju, dzięki czemu namiestnik przystał na pewne ograniczenia w systemie środków karnych, służących stłumieniu ruchu antyrządowego, z drugiej zaś efekt zmiany strategii walki stosowanej przez partie powstańcze. Naczelników wojennych obarczono powinnością

194 Sbornik cirkuljarow wojenno-policejskogo uprawlienija w Carstwie Polskim 1863-1866 (dalej: SCW-PUwCP), Warszawa 1867, s. 4-5.

195 Ibidem.

196 Archiwum Państwowe w Lublinie, Zarząd Naczelnika Wojennego Powiatu Łukowskiego, sygn.. 39, k. 150-152. 
wysyłania do Audytoriatu Polowego dokumentacji spraw, w jakich zapadły ostateczne wyroki w stosunku do winnych przypisanych w całości do dwóch pierwszy kategorii, jak i trzeciej, ale tylko w odniesieniu do osób ze stanów uprzywilejowanych. W przeciwieństwie do rozwiązań przyjętych 24 maja $1863 \mathrm{r}$. zmieniło się przyporządkowanie uczestników rewolty do poszczególnych grup. Pierwsza skupiała teraz: przywódców walczących oddziałów, członków Rządu Narodowego, zagranicznych emisariuszy odpowiedzialnych za wydawanie rozkazów o wykonywaniu zabójstw politycznych, dezerterów z armii carskiej i wszystkich, którzy dobrowolnie przyłączyli się do irredenty. Do drugiej wchodzili: 1) komisarze organizujący partie zbrojne; 2) powstańczy naczelnicy miast, powiatów i policji; 3) naczelnicy oddziałów tzw. żandarmów wieszających, parających się zabójstwami politycznymi, grabieżami i znęcaniem się nad ludnością cywilną; 4) podburzający chłopów do rozruchów oraz 5) urzędnicy i duchowni, będący członkami organizacji rewolucyjnej lub wspierających ją z racji piastowanych stanowisk. Do trzeciej kategorii zaliczono: żandarmów Straży Narodowej. W odniesieniu do pierwszej grupy rodzaj wyroku ferowanego w oparciu o karne ustawy wojskowe, był całkowicie uzależniony od decyzji sądu i naczelnika wojennego. Na winnych drugiej kategorii spadały takie same sankcje, jakie praktykowano w piśmie okólnym z 24 maja. Natomiast skazanych z grupy trzeciej i zakwalifikowanych do wyższych warstw społeczeństwa (w tym szlachetnie urodzonych) czekała zsyłka do rot aresztanckich bądź mniej odległych miejscowości syberyjskich, z utratą wszystkich praw specjalnych oraz przywilejów osobistych i stanowych, jak również osadzenie w twierdzy na okres od 6 miesięcy do 2 lat ${ }^{197}$.

Audytoriat Polowy uzyskał uprawnienia tylko do rewizji spraw z udziałem przedstawicieli wyższych warstw społeczeństwa polskiego, traktowanych przez rządzących za głównych prowodyrów i przywódców powstania, a więc element najbardziej niebezpieczny, który należało przykładnie ukarać. W przypadku niestwierdzenia przez sędziów żadnych uchybień proceduralnych, przeanalizowana (zrewidowana) pod względem zgodności z obowiązującym prawem dokumentacja procesowa trafiała do namiestnika i zarazem głównodowodzącego, posiadającego - podobnie jak naczelnicy wojenni - wyłączne prerogatywy do zatwierdzania końcowych wyroków. Następnie Dyżurstwo Sztabu Wojsk w Królestwie Polskim przekazywało podpisane przez namiestnika wyroki naczelnikom wojennym, do których należało wprowadzenie ich w życie. W razie stwierdzenia jakichś błędów w aktach sprawy, wyższy sąd rewizyjny je korygował i dopiero wtedy przekazywał namiestnikowi ${ }^{198}$.

197 Ibidem.

198 Archiwum Państwowe w Kielcach (dalej: APK), Dowodzący wojskami w powiatach kieleckim, stopnickim i sandomierskim (dalej: DWwPKSS), sygn. 2, s. 94-95. 
Obowiązujące procedury w zakresie orzecznictwa sądowego i zasad wymierzania sprawiedliwości nie zawsze były respektowane przez naczelników wojennych. Niektórzy z nich, nie zwracając uwagi na wyraźny podział kompetencji do konfirmowania werdyktów komisji sądowych pomiędzy nich i namiestnika, zaraz po wydaniu rozkazu z 4 lutego 1863 r. zaczęli odsyłać do Audytoriatu Polowego akta wszystkich bez wyjątku spraw, choć ten ostatni nie był władny do przeprowadzania ich audytów. W rezultacie tracił on czas na przekierowywanie dokumentacji do odpowiednich instytucji ${ }^{199}$. Musiało to powodować spory bałagan w całościowym systemie wymiaru sprawiedliwości i zapewne jakieś zgrzyty kompetencyjne, skoro 29 marca 1863 r. oddział oberaudytora przy Dyżurstwie Sztabu Wojsk w Królestwie Polskim wyjaśniał naczelnikom wojennym, że do wyższego sądu rewizyjnego powinny trafiać wyłącznie przydzielone mu kategorie spraw $^{200}$. Identycznie rzecz się miała po opublikowaniu cyrkularza z 24 maja ${ }^{201}$. Zatem obowiązujący w rosyjskim prawodawstwie wojskowym rewizyjny system zatwierdzania wyroków sądowych w warunkach wojennych, kiedy władzom zależało na maksymalnie najszybszym ujarzmieniu buntu, nie działał sprawnie. Wynikało to z chęci koncentracji w rękach naczelników wojennych możliwie najszerszych kompetencji, z czym niektórzy z nich niekiedy sobie nie radzili, zwłaszcza że ich zakres obowiązków stale się zmieniał. $\mathrm{Z}$ tego powodu w tajnym piśmie namiestnika z 10 grudnia 1864 r. adresowanym do naczelników wojennych oddziałów głównych, polecono im wnosić do rewizji w Audytoriacie Polowym wszystkie doprowadzone do końca przez sądy wojskowe sprawy o uczestnictwo w insurekcji, których konfirmacja przekraczała ich kompetencje ${ }^{202}$. Wraz ze stopniową likwidacją ognisk polskiego oporu Audytoriat Polowy otrzymywał do rewizji sprawy odnoszące się do coraz większej liczby wyodrębnionych przez rząd rosyjski kategorii osób uznanych za winnych udziału w powstaniu. Tym samym naczelnicy wojenni - przewidziani do działań w warunkach nadzwyczajnych stopniowo tracili ogromne kompetencje sądowe na rzecz namiestnika. Co więcej, zdarzały się wypadki niedostarczania przez nich do sztabu sprawozdań na temat ilości prowadzonych w ich oddziałach spraw sądowych przeciwko przestępcom politycznym, z podziałem na te, które zostały doprowadzone do końca oraz te, w których wyrok oczekiwał jeszcze na konfirmację namiestnika. W drugim przypadku winę za zwłokę ponosił Audytoriat Polowy, toteż naczelników zobligowano do podawania dokładnej daty skierowania akt do rewizji ${ }^{203}$.

\footnotetext{
199 APR, ZNWOR, sygn. 34, s. 115-117.

${ }^{200}$ Ibidem, s. 119-121.

${ }^{201}$ AGAD, Zarządy Naczelników Wojennych w Królestwie Polskim, sygn. 30, k. 40.

202 SCW-PUwCP, s. 44-45.

${ }^{203}$ APK, DWwPKSS, sygn. 2, s. 94-95.
} 
Chociaż powstanie zostało w zasadzie zdławione do końca 1864 r., to agendy administracji specjalnej w postaci oddziałów wojennych przetrwały jeszcze dwa lata. Dopiero w stycznia 1867 r. wszedł w życie ukaz cesarski z 19 grudnia ubiegłego roku wprowadzający zmiany w całościowej strukturze administracyjnej Królestwa Polskiego. Przyniosły one likwidację instytucji naczelników wojennych ${ }^{204}$. Proces ten trwał już od kilku miesięcy, bowiem do 19 marca 1866 r. zostali oni zobligowani do przekazania swych uprawnień gubernatorom cywilnym. W efekcie wszystkie sprawy o udział w rebelii wojskowe sądy polowe musiały przekazać teraz do Audytoriatu Polowego wojsk Warszawskiego Okręgu Wojskowego (dalej: WOW; właśnie taka nazwa zaczęła pojawiać się w archiwaliach od 1866 r. $)^{205}$. Instytucja Audytoriatu Polowego, która po doświadczeniach kolejnego polskiego zrywu narodowowyzwoleńczego powróciła na początku 1867 r. do normalnego trybu pracy, przetrwała do 2 marca 1874 r., kiedy w jej miejsce powołano tzw. pion sądowy przy dowodzącym jednostkami wojskowymi WOW oraz tymczasowy wydział przy Głównym Wojskowym Zarządzie Sądowym ${ }^{206}$.

Z powstaniem styczniowym wiązała się również działalność - wspomnianego już - Tymczasowego Audytoriatu Polowego przy Sztabie głównodowodzącego wojskami Wileńskiego Okręgu Wojskowego. Funkcjonujący pomiędzy 12 lipca 1863 r. a 12 stycznia 1867 r., zasięgiem swego oddziaływania obejmował gubernie litewskie (wileńską, kowieńską, grodzieńską, mohylewską, mińską oraz do 1864 r. inflancką i kurlandzką). Pod względem struktury wewnętrznej organ ten, przeznaczony do prowadzenia śledztw i procesów sądowych przeciwko powstańcom, był wzorowany na rozwiązaniach przyjętych dla audytoriatów polowych 1. Armii oraz Armii Kaukaskiej. W jego skład wchodził: przewodniczący (generał major lub generał lejtnant), członkowie (w stopniach sztabsoficerskich), polowy oberaudytor z zastępcą i audytor do prac kancelaryjnych. Roczny koszt pracy rzeczonego sądu rewizyjnego opiewał na sumę rzędu 9347 rubli i 10 kopiejek $^{207}$.

Własnym audytoriatem polowym dysponowała również istniejąca od października 1814 r. do lipca 1830 r. 2. Armia, której korpusy zajmowały terytorium guberni podolskiej ${ }^{208}$. Jego etat został zatwierdzony 29 lipca 1824 r. W dokumencie ustawodawca zalecał, aby w swej działalności kierował się przepisami wydanymi 4 czerwca 1823 r. w odniesieniu do identycznej instytucji funkcjonującej

204 Archiwum Państwowe w Łodzi, Kancelaria Gubernatora Piotrkowskiego, sygn. 1, s. 5.

${ }^{205}$ APR, Kancelaria Gubernatora Radomskiego, sygn. 1, s. 228-229.

${ }^{206}$ PSZRI (II), t. 49, odt. 1, nr 53214, s. 320-321.

${ }^{207}$ PSZRI (II), t. 38, odt. 1, nr 39862, s. 1841-1842; odt. 2, s. 189; t. 42, odt. 1, nr 44104, s. 12.

${ }^{208}$ PSZRI (I), t. 32, nr 25723, s. 1077; PSZRI (II), t. 5, nr 3768, s. 688. A.A. Kiersnowskij, op.cit., s. 18. 
przy 1. Armii. W przeciwieństwie do tej ostatniej Audytoriat Polowy 2. Armii posiadał jednowydziałową kancelarię. Utrzymanie całego personelu zatrudnionego w wyższych sądach rewizyjnych obu rzeczonych armii kosztowało skarb państwa 16260 rubli rocznie ${ }^{209}$.

Począwszy od schyłku lat 30 . XIX w. służby audytorskie zaczęły się pojawiać na poziomie różnych struktur taktycznych oraz w niektórych instytucjach o charakterze wojskowo-administracyjnym. Dwudziestego szóstego stycznia 1839 r. przyjęto ukaz o mianowaniu po jednym młodszym audytorze przy sztabach dywizji artylerii gwardyjskiej i kaukaskiej oraz sześciu dywizji polowych. Tego samego roku, 17 marca, oberaudytora (nie odrębny audytoriat) z roczną pensją 1200 rubli zainstalowano w Dyżurstwie Wojska Dońskiego ${ }^{210}$. Własnymi instytucjami audytorskimi dysponował również Samodzielny Korpus Kaukaski. Jego dwuwydziałowy Audytoriat Polowy, pracujący w oparciu o etat z 4 grudnia 1846 r. grupował: przewodniczącego w randze generała majora, trzech członków w stopniach pułkowników, polowego generała audytora, dwóch oberaudytorów (każdy stał na czele wydziału) z czterema audytorami (w charakterze zastępców), audytora zarządzającego sekretariatem i dziesięciu pisarzy. Ich utrzymanie wraz z wydatkami kancelaryjnymi kosztowało rocznie skarb państwa 3749 rubli i 57 kopiejek w srebrze ${ }^{211}$. Po przeformowaniu w 1857 r. rzeczonego korpusu w Armię Kaukaską, w oparciu o ustawą o jej zarządzie z 1 kwietnia 1858 r., przy rzeczonej formacji zainstalowano identyczną agendę. Dodatkowo przy dyżurstwach sztabów całej armii i kutaiskiego generał-gubernatora, jak również dyżurstwach zarządów poszczególnych linii obronnych (lezgińskiej i kaukaskiej prawego skrzydła) przebywało po jednym oberaudytorze i audytorze ${ }^{212}$. Audytoriat Polowy Armii Kaukaskiej, przemianowanej 6 sierpnia 1865 r. w Kaukaski Okręg Wojskowy, ale z zachowaniem dotychczasowej nazwy, przetrwał do 23 kwietnia 1874 r., kiedy dokonano jego likwidacji ${ }^{213}$.

Audytoriaty Polowe tworzone wyłącznie przy armiach i samodzielnych korpusach zawsze stanowiły pion sądowy ich sztabów, całkowicie podległy naczelnym dowódcom posiadającym prawo do zatwierdzania wyroków sądów wojskowych. Dlatego rola tych agend w systemie wymiaru sprawiedliwości na poziomie struktur taktyczno-operacyjnych sprowadzała się jedynie do funkcji kontrolnych i prowadzenia sprawozdawczości.

\footnotetext{
${ }^{209}$ PSZRI (I), t. 39, s. 458; t. 43: kniga sztatow, cz. 2, s. 213.

210 PSZRI (II), t. 14, nr 12136, otd. 3, s. 253.

211 PSZRI (II), t. 21, otd. 3, s. 178.

${ }^{212}$ PSZRI (II), t. 33, odt. 1, nr 32938, s. 370; odt. 3, s. 130-133, 156, 158.

213 PSZRI (II), t. 40, odt. 1, nr 42368, s. 851; t. 49, odt. 1, nr 53413, s. 673.
} 


\section{STATUS SŁUŻBOWY I ZASADY KSZTAŁCENIA AUDYTORÓW}

W ostatnich latach panowania Piotra I stosunkowo wysoka pozycja urzędników audytorskich w siłach zbrojnych uległa obniżeniu. Według etatu armijnego z 9 lutego 1720 r. oraz Tabeli o rangach z 24 stycznia 1722 r. generałów audytorów wojsk lądowych przypisano do 7 klasy (na równi z podpułkownikami), generałów audytorów lejtnantów - do 8 klasy (na równi z majorami), oberaudytorów sił lądowych i artylerii - do 9 klasy (na równi z kapitanami), zaś audytorów w artylerii - do 10 klasy (na równi z lejtnantami) ${ }^{214}$. Audytorom pułkowym, $\mathrm{z}$ wyjątkiem tych służących $\mathrm{w}$ artylerii (równych kapitanom lejtnantom), wcale nie wyznaczono rangi, a pod względem uposażenia pieniężnego stali oni niżej od chorążych, i tylko nieco wyżej od pisarzy pułkowych. Zdarzały się jednak przypadki ich promowania na podporuczników, ale jeśli pozostawali audytorami, to dalszy awans następował tylko po ich przeniesieniu do linii lub resortu cywilnego. Niekiedy wyznaczano im również rangi cywilne. $Z$ tego względu dowódcy pułków na stanowiska audytorów pułkowych wyznaczali zazwyczaj umiejących pisać i czytać feldfebli, podoficerów i pisarzy, awansowanych w pierwszej kolejności spośród tzw. dzieci żołnierskich (osobiście wolni synowi żołnierzy wywodzący się z chłopstwa pańszczyźnianego), które zdobyły wykształcenie w - powołanych z myślą o nich - szkołach garnizonowych (inaczej pułkowych) ${ }^{215}$.

Dopiero w ukazie z 30 czerwca 1728 r. znalazła się norma polecająca nadawanie audytorom pułkowym stopni oficerskich, analogicznie do kwatermistrzów, komisarzy taborowych, fiskałów czy lekarzy, co najlepiej odzwierciedla pozycję, jaką ci pierwsi posiadali w armii ${ }^{216}$. Audytorów uznawano po prostu za cześć służb logistycznych. Podobne tendencje dominowały w następnych latach. W 1752 r. lub 1754 r. zaczęto praktykować mianowanie w pułkach liniowych na wakaty audytorskie młodszych - a w razie ich braku - starszych chorążych. Faktycznie nadal przeważali wśród tych urzędników podoficerowie i skrybowie wojskowi, niemniej dowództwo zalecało, aby na wolne etaty w piechocie i kawalerii kierować podporuczników, z zagwarantowaniem im, tak samo jak pozostałym oficerom, możliwości dalszego awansu ${ }^{217}$. Od 1862 r. podobne podejście zaczęło dominować w formacjach artyleryjskich i inżynieryjnych.

Kiedy na tronie rosyjskim zasiadł Piotr III, to - analogicznie do wzorców pruskich - wydał rozkaz obsadzania stanowisk audytorskich w pułkach przez posiadaczy klejnotów szlacheckich, czyli w domyśle oficerów, zakazując im jednak

\footnotetext{
${ }^{214}$ PSZRI (I), t. 6, nr 3890, s. 486-490; t. 43: kniga sztatow, cz. 1, s. 15-38.

${ }^{215} S W M$, t. 12, cz. 1, k. 1, s. 140-141, 190.

${ }^{216}$ PSZRI (I), t. 8, nr 5298, s. 59.

${ }^{217} S W M$, t. 12, cz. 1, k. 1, s. 141.
} 
noszenia znaków oficerskich, szarf i temblaków przy szablach ${ }^{218}$. Pozbawienie audytorów tych wszystkich elementów umundurowania i uzbrojenia, stanowiących zewnętrzne atrybuty przypisane stopniowi oficerskiemu, stawiało ich w znacznie gorszej sytuacji służbowej w porównaniu do położenia ich kolegów z jednostek liniowych, tym bardziej że odebrano im możliwość promocji powyżej rangi podporucznika. Dalszy awans zapewniało im jedynie przejście do resortu cywilne$\mathrm{go}^{219}$. W praktyce u schyłku XVIII w. audytorzy rozpoczynali służbę bez żadnej rangi państwowej, ale zgodnie z rozkazem z 11 lutego 1799 r. mogli ją uzyskać razem z właściwym tytułem i prawem do noszenia uniformu audytorskiego za wzorowo pełnioną służbę, wyłącznie z nominacji generała audytora, od którego decyzji zależały także ich awanse ${ }^{220}$. Ukaz z października (brak daty dziennej) 1799 r. zapewniał im maksymalnie rangę IX (radcy tytularnego), a wyższe stopnie w hierarchii służbowej stały się dla nich niedostępne. Jej uzyskanie dawało posiadaczowi widoki na objęcie - na wniosek szefa pułku, ale wyłącznie w razie potrzeby - stanowiska kwatermistrza ${ }^{221}$.

Dekret z 21 lipca 1802 r. potwierdzał powyższy stan rzeczy, ponieważ władze godziły się na promowanie audytorów pułkowych tylko w obrębie rang od XIII (sekretarz prowincjonalny) do IX (radca tytularny) i to po przesłużeniu w każdej $\mathrm{z}$ nich trzech lat ${ }^{222}$. Ich awans na asesora kolegialnego (ranga VIII), który gwarantował wówczas uzyskanie szlachectwa rodowego - w myśl dekretu z 9 czerwca 1804 r. - dopuszczano nie inaczej jak po wysłudze w randze radcy tytularnego nie mniej niż czterech lat, w odniesieniu do szlachty oraz co najmniej ośmiu lat w przypadku osób pochodzenia nieszlacheckiego, z wymaganym ich przesunięciem na przypisany tej randze urząd $\mathrm{w}$ resorcie cywilnym ${ }^{223}$. Toteż szlachcic nie mógł pełnić obowiązków audytora w regimencie. Zakaz ten oficjalnie usankcjonowano w ukazie z 1 września 1803 r., co stanowiło bolesny cios w pozycję służbową audytorów pułkowych ${ }^{224}$. Uznano ich za urzędników cywilnych, poważnie ograniczając im 7 marca 1808 r. możliwość przeniesienia do kategorii oficerów liniowych. Rząd zrobił wyjątek tylko dla tych, którzy do momentu mianowania na audytora mieli za sobą 12 lat służby polowej ${ }^{225}$. Odstępstwo od reguły uczy-

${ }^{218}$ Ibidem. Do 1845 r. stopień chorążego, potem ranga majora, natomiast od 1856 r. szlify pułkownika oznaczały uzyskanie szlachectwa rodowego. Z kolei posiadacz każdej niższej szarży oficerskiej posiadał szlachectwo osobiste; zob. S.W. Wołkow, Russkij oficerskij korpus, Moskwa 1993, s. 266-267, 270.

219 SWM, t. 12, cz. 1, k. 1, s. 141.

${ }^{220}$ PSZRI (I), t. 25, nr 18853, s. 555; nr 19023, s. 693.

${ }^{221}$ PSZRI (I), t. 25, nr 19175, s. 849.

222 PSZRI (I), t. 27, nr 20337, s. 198.

${ }^{223}$ PSZRI (I), t. 28, nr 21337, s. 372.

${ }^{224}$ PSZRI (I), t. 27, nr 20929, s. 881.

225 PSZRI (I), t. 30, nr 22876, s. 112. 
niono również dla audytorów pracujących w Audytoriacie Generalnym, jednostkach gwardyjskich, ordonans-hauzach oraz przy głównodowodzących korpusami. Wszyscy oni - w myśl aktów prawnych opublikowanych 8 września 1805 r., 25 stycznia 1808 r., 1 kwietnia 1808 r. i 6 sierpnia 1809 r. - mogli otrzymać rangę asesora kolegialnego i tym samym wejść do grona warstwy uprzywilejowanej226.

$\mathrm{Na}$ wyższe urzędy audytorskie (generał audytor, generał audytor lejtnant i oberaudytor) od 1722 r. wyznaczano oficerów w stopniach podpułkowników, majorów i kapitanów. Poczynając od drugiej połowy XVIII w. uzyskiwali oni niekiedy nawet wyższe rangi oficerskie, mianowicie pułkowników i brygadierów, ale ich dalszy awans wchodził w grę tylko po przejściu do struktur cywilnych ${ }^{227}$. Nadanie rang cywilnych audytorom pułkowym zmusiło władze do podjęcia analogicznych działań wobec ich odpowiedników na wyższych szczeblach funkcyjnych, zwłaszcza że generałów audytorów lejtnantów oraz oberaudytorów w większości rekrutowano właśnie z grona audytorów pułkowych. Cytowane powyżej dekrety z 8 września 1805 r., jak i 1 kwietnia 1808 r. nadawały zatrudnionym w Audytoriacie Generalnym generałowi audytorowi lejtnantowi rangi od VIII do VI (radca kolegialny), natomiast oberaudytorom - od IX do VII (radca dworu). Taki sam przedział obowiązywał w stosunku do, służących przy dowódcach korpusów i dywizji oberaudytorów, oraz generałów audytorów lejtnantów przy głównodowodzących armiami ${ }^{228}$.

W myśl regulaminów służby polowej piechoty i kawalerii z 29 listopada 1796 r. na audytorów, z jednej strony spadły powinności natury czysto sądowej (prowadzenie śledztw w sprawach oficerów i niższych rang), jak i gospodarczej. Do tych ostatnich zaliczało się zawiadywanie taborem pułkowym, a w czasie wojny - w razie braku kwatermistrza - przyjmowanie prowiantu oraz furażu. W jednostkach garnizonowych i batalionach jegrów dosłownie obarczono ich obowiązkami kwatermistrzowskimi. Chorych audytorów w ich powinnościach wiążących się z wymiarem sprawiedliwości zastępowali feldfeble ${ }^{229}$. W sumie obciążenie audytorów pułkowych pracą na rzecz intendentury utrudniało czy wręcz czyniło niemożliwym pełnienie roli strażników prawa, mających ukierunkować tok rozprawy, o czym mówił Regulamin Wojskowy z 1716 r. Notabene, za rządów

${ }^{226}$ PSZRI (I), t. 28, nr 21904, s. 1218; t. 30, nr 22781, s. 44; nr 22932, s. 164; nr 23772, s. 1057.

227 SWM, t. 12, cz. 1, k. 1, s. 143.

${ }^{228}$ PSZRI (I), t. 28, nr 21904, s. 1218; t. 30, nr 22932, s. 164.

${ }^{229}$ Woinskij ustaw o poliewoj piechotnoj stużbie, St. Pietierburg 1797, s. 86; PSZRI (I), t. 24, nr 17590, s. 184. Fakt obarczenia audytorów pułkowych działalnością gospodarczą potwierdzał, przytoczony już powyżej, ukaz z 2 kwietnia 1802 r. Zgodnie z nim w formacjach garnizonowych złożonych z kilku batalionów, które posiadały tylko płatnika i audytora, przyjmowanie i dystrybucja prowiantu pomiędzy pododdziały należały - w zastępstwie kwatermistrza - do tego drugiego lub w razie jego braku do płatnika; zob. PSZRI (I), t. 27, nr 20215, s. 88. 
Aleksandra I urzędnicy ci na płaszczyźnie sądowej zajmowali się już tylko obowiązkami kancelaryjnymi oraz wyszukiwaniem ustaw, odpowiednich do charakteru prowadzonej w kriegsrechcie sprawy. Reasumując, audytorzy parali się działalnością właściwą dla personelu niższego sztabu pułkowego, zajmując pozycję pośrednią pomiędzy oficerami a podoficerami ${ }^{230}$.

Początkowo audytorzy i oberaudytorzy otrzymywali uposażenie stosownie do posiadanych rang, z tym że znaczący wpływ na jego wysokość miało miejsce pełnienia służby. Największe pobory urzędnicy ci pobierali w gwardii, najmniejsze zaś $\mathrm{w}$ jednostkach garnizonowych. W pułkach armijnych z kolei wynagrodzenie plasowało się na średnim poziomie. Do kieszeni audytora VIII rangi trafiało w skali roku 530 rubli. Audytor XIII rangi w pułku garnizonowym otrzymywał 125 rubli, zaś w pozostałych formacjach - 236 rubli $^{231}$.

Tymczasem w 1817 r. pojawiła się ogromna ilość wakatów na stanowiskach audytorskich. Stanowiło to następstwo wzrostu ich etatowej liczby, jak również poszerzenia prerogatyw sądowych wyższych dowódców wojskowych. Deficyt ten wzrósł jeszcze bardziej w latach następnych, głównie z powodu pojawienia się osiedli wojskowych, którym przypisano własnych audytorów. Władze próbowały ratować sytuację obsadzając wolne stanowiska feldfeblami i niższymi podoficerami. Spotykało się to jednak z ich powszechną niechęcią, albowiem odejście z linii pozbawiało ich widoków na awans oficerski. Zresztą audytorami z reguły nie zostawali najwłaściwsi do tej profesji podoficerowie. Niemniej, jeśli w końcu nastąpiła nominacja, to po pewnym czasie adepci nabierali pewnego doświadczenia $\mathrm{w}$ zakresie prowadzenia prac kancelaryjnych w pionie sądowniczym i stawali się cenionymi specjalistami, gdyż ich powinności często - z przymusu - musieli pełnić feldfeble z jednostek polowych, niemających najczęściej pojęcia o specyfice rzemiosła audytorskiego. Z drugiej strony, urzędnicy resortów cywilnych, z powodu braku specjalistycznej wiedzy, nieobeznania z tajnikami spraw wojskowych i konieczności ponoszenia dużej odpowiedzialności osobistej, rzadko byli skłonni rozpoczynać karierę w strukturach sądownictwa lądowych sił zbrojnych, sparaliżowanych w pierwszym dziesięcioleciu XIX w. z racji ogromnych niedoborów dobrze przygotowanych kadr audytorskich na poziomie pułków ${ }^{232}$.

Wyżej opisana sytuacja zmusiła czynniki rządowe do reakcji na rzecz poprawy położenia pracowników instytucji audytorskich. Stosownie do opublikowanej 1 sierpnia 1817 r. tabeli uposażeń pieniężnych, w zależności od rangi i miejsca pełnienia służby oberaudytorzy uzyskali kwoty rzędu 600-1000 rubli, a audy-

\footnotetext{
230 SWM, t. 12, cz. 2, k. 1, s. 106.

${ }^{231}$ Ibidem, s. 107.

${ }^{232}$ Ibidem.
} 
torzy pułkowi - 350-750 rubli rocznie ${ }^{233}$. Zwiększono pobory audytorom garnizonowym; zamiast 125 rubli mieli teraz otrzymywać 350 rubli na rok. Jednocześnie, na takich samych zasadach jak oficerom, oberaudytorom i audytorom zaczęli przysługiwać ordynansi. $\mathrm{Z}$ kolei audytorom pracującym $\mathrm{w}$ departamencie audytorskim przydzielono sumy zgodnie z etatem z 1812 r., ale na specjalnych zasadach. I tak: generałowi audytorowi przysługiwało w stosunku rocznym 4000 rubli, jego zastępcy - 3000 rubli, radcy wojskowemu - 2000 rubli, naczelnikowi wydziału w randze oberaudytora - 2500 rubli, naczelnikowi referatu w randze audytora - 1200 rubli, zaś ich pomocnikom - po 750 rubli $^{234}$.

Prawidłowe funkcjonowanie służb audytorskich w armii było uzależnione od poziomu wiedzy oraz umiejętności zatrudnionego w nich personelu. Dobór właściwej liczby pracowników, mogących się poszczycić odpowiednią wiedzą fachową - na co ustawodawca zwracał uwagę już w pierwszych latach XVIII w. okazał się niezwykle trudny w Rosji, nie posiadającej własnych tradycji kształcenia uniwersyteckiego w zakresie nauk prawnych. W czasach Piotra I udało się pozyskać do pracy, przede wszystkim do agendach audytorskich wyższego szczebla, kilku cudzoziemskich jurystów. Znacznie gorzej sytuacja przedstawiała się w pułkach, gdzie zawsze było wiele wakatów. Początkowo próbowano je obsadzać audytorami szwedzkimi, którzy dostali się do rosyjskiej niewoli podczas Wojny Północnej. Dawało to jednak nikłe rezultaty. $Z$ tego względu podstawowym źródłem uzupełniania braków kadrowych stawali się doświadczeni i, co najistotniejsze, umiejący pisać i czytać oficerowie rosyjscy. W wielu jednostkach obowiązki audytorów pełnili pisarze w stopniach oficerskich ${ }^{235}$. Niewystarczająca ilość odpowiedniego personelu skłoniła Piotra I w 1719 r. do wydania polecenia o naborze młodych szlachciców do Kolegium Wojny, w celu uzyskania przez nich kwalifikacji audytorskich. Braki w kadrze pedagogicznej tej - de facto pierwszej w Cesarstwie Rosyjskich szkoły nauk prawnych - uzupełniano najpierw zapraszając specjalistów z Czech, a potem kierując do pracy własnych nauczycieli. Niestety i ta inicjatywa nie rozwiązała problemu, podobnie zresztą jak i wyjazdy za granicę synów szlachty w celu nabycie umiejętności jurystycznych ${ }^{236}$.

Wzrost zapotrzebowania na dobrze wykształcony personel prawniczy nastąpił z chwilą utworzenia Audytoriatu Generalnego i departamentu audytorskiego. Wynikał ponadto z poszerzenia uprawnień sądowych wyższych dowódców wojskowych, rozbudowy polowych instytucji audytorskich przy armiach i samodzielnych korpusach, jak również powołania i rozbudowy sieci osiedli wojskowych.

233 PSZRI (I), t. 34, nr 26981, s. 462.

${ }^{234}$ Ibidem; $S W M$, t. 12, cz. 2, k. 1, s. 108.

235 M.O. Akiszin, op.cit., s. 123, 125-126.

${ }^{236}$ S.S. Sibiliew, Istorija podgotowki kadrow dlja organow juridiczeskoj stużby woorużennych sit Rossii, „Fiemida.Science” 2015, nr 1, s. 42. 
Problem niedoborów kadrowych starano się rozwiązać, kierując kantonistów (niepełnoletni synowie podoficerów i szeregowców zobowiązani z racji swego pochodzenia do służby w siłach zbrojnych) na szkolenia do departamentu audytorskiego i ordonans-hauzów. O korzyściach, wynikających z tego typu działań, wspominano w regulacji z 28 października 1819 r., zalecając wyznaczać zdolnych podoficerów i pisarzy, którzy przepisując korespondencję dla departamentu audytorskiego i sądów wojskowych mogliby zdobywać wiedzę oraz doświadczenia na płaszczyźnie teorii prawa i praktyki sądowej. Ogółem zamierzano wówczas wykształcić 80 audytorów, z czego po trzech zamierzano odesłać do departamentu audytorskiego i Sztabu Głównego, a 17 - do ordonans-hauzów ${ }^{237}$.

Innym kanałem przygotowywania kadr było kształcenie przyszłych pracowników bezpośrednio przy instytucjach audytorskich. Dla przykładu wystarczy wspomnieć o urzędnikach w rangach sekretarzy gubernialnych, registratorów kolegialnych i radców honorowych oddelegowanych na szkolenia do Audytoriatu Polowego Armii Czynnej w liczbie: 27 w 1853 r., 36 w 1854 r. oraz 2 w 1855 r. ${ }^{238}$.

Równocześnie władze przystąpiły do wprowadzania we wszystkich szkołach wojskowych specjalnych kursów z dziedziny prawoznawstwa ${ }^{239}$. Od 1832 r. uruchomiono przy petersburskim batalionie kantonistów Szkołę Audytorską, obliczoną na 100 uczniów, która status samodzielnej placówki uzyskała w 1846 r. Jej zadaniem było kształcenie uczniów w myśl „zasady czystej moralności chrześcijańskiej, miłości do bliźniego i niezłomnego oddania dla Tronu i Ojczyzny”. Według rozporządzenia z 2 sierpnia 1860 r. nauki w tej placówce mogło pobierać już 170 osób, w tym 150 na koszt państwa. Podzielona na pięć klas (trzy wyższe - specjalne i dwie niższe), nigdy nie zdołała przygotować wymaganej ilości audytorów ${ }^{240}$. Dlatego, podobnie jak w latach wcześniejszych, władze musiały uciekać się do naboru z grona feldfeblów, wachmistrzów oraz pisarzy wojskowych. Rok 1866 r. przyniósł uruchomienie przy Szkole Audytorskiej - ostatecznie zli-

${ }^{237}$ PSZRI (I), t. 36, nr 27959, s. 363; t. 43: kniga sztatow, cz. 2, s.106. Zgodnie z ustawą z 24 lutego 1817 r. kantoniści przygotowywani na audytorów przy ordonans-hauzach powinni jeszcze przez rok podnosić swe kwalifikacje u boku korpusowych oberaudytorów, od których decyzji była uzależniona ich nominacja na audytorów. Po promocji władze dawały im możliwość uzyskania rangi oficerskiej w ciągu 3 lat; zob. PSZRI (I), t. 34, nr 26694, s. 85.

238 Rocznik urzędowy obejmujacy spis naczelnych władz Cesarstwa oraz wszystkich władz i urzędników Królestwa Polskiego na rok 1853, Warszawa 1853, s. 123-124; na rok 1854, Warszawa 1854, s. 121-122; na rok 1855, Warszawa 1855 , s. 121.

239 A.S. Janczew, op.cit., s. 129-130. W 1836 r. ujednolicono program nauczania we wszystkich korpusach kadetów. Wśród przedmiotów obowiązkowych znalazła się również jurysprudencja, chociaż wykładano ją już w XVIII w. w Lądowym Korpusie Kadetów (od 1866 r. Cesarski Korpus Kadetów); zob. L.G. Bieskrownyj, Russkaja armija i flot $w$ XIX wiekie. Wojenno-ekonomiczeskij potencjat Rossii, Moskwa 1973, s. 125; SWM, t. 12, cz. 1, k. 1, s. 143.

${ }^{240}$ PSZRI (II), t. 7, nr 5253, s. 167-169; t. 21, odt. 2, nr 20422, s. 281289. 
kwidowanej w 1878 r. - klasy oficerskiej, przemianowanej później ma Akademię Wojskowo-Prawniczą ${ }^{241}$.

Niewystarczająca liczba wyspecjalizowanych placówek oświatowych i odpowiednio wykształconych kadr pedagogicznych negatywnie odbijały się na poziomie przygotowania fachowego audytorów, niezależnie od zajmowanego przez nich stanowiska. Dlatego na początku lat 60 . XIX w., kiedy przystąpiono do reorganizacji całościowego systemu wymiaru sprawiedliwości w lądowych siłach zbrojnych, zaczęto przykładać większą uwagę do poziomu przygotowania personelu sądowego. W 1861 r. nastąpiło poszerzenie programu nauczania w Szkole Audytorskiej. Efektem tego typu posunięć był wzrost liczby audytorów, którzy ukończyli kursy w wyższych i średnich placówkach szkolnych. Rosyjskie źródła urzędowe wspominają o 364 takich urzędnikach (na ogólną liczbę 673) w $1862 \mathrm{r}^{242}$.

Na początku lat 20. XVIII w. w armii znajdowało się zaledwie 132 urzędników audytorskich ${ }^{243}$. W 1817 r. liczba ta zwiększyła się do 71 oberaudytorów i 312 audytorów. Uwzględniając wielkości etatowe, brakowało w sumie 118 pracowników obu tych szczeblii ${ }^{24}$. Następne lata przyniosły wzrost i ustabilizowanie się ogólnej liczebności audytorów na poziomie od $830 \mathrm{w} 1837$ r. do 989 w 1855 r. ${ }^{245}$. Od 1862 r. etatowa oraz faktyczna ich liczba zaczęła stale się zmniejszać do: 891 w 1863 r., 809 w 1864 r., 742 w 1865 r., 806 w 1866 r. oraz 772 w 1867 r., przy niedoborach etatowych na poziomie od 37 do nawet 145 . Co prawda, pomiędzy 1863 r. a 1867 r. powołano 324 nowe etaty audytorskie, ale jednocześnie zlikwidowano aż $423^{246}$. W ciągu ostatnich 5 latach funkcjonowania instytucji audytorskich $\mathrm{w}$ armii władze stale borykały się $\mathrm{z}$ trudnościami podczas obsadzania wakatów w nowo formowanych pułkach i dywizjach. Na domiar złego ogłoszenie stanu wojennego w Królestwie Polskim oraz w Kraju Północno-Zachodnim i Południowo-Zachodnim, a potem wybuch na tych obszarach powstania w $1863 \mathrm{r}$., pociągnęły za sobą intensyfikację działalności sądów wojskowych, co zwiększyło zapotrzebowanie na personel sądowy. Na tereny objęte walkami zaczęto odkomenderowywać audytorów z wojsk dyslokowanych w guberniach wewnętrznych. Do 1864 r. tym sposobem udało się pozyskać łącznie 28 audytorów różnych rang ${ }^{247}$. Z korespondencji Sztabu Wojsk w Królestwie Polskim z naczelnikiem wojennym oddziału radomskiego z 26 lutego 1863 r. wynika, że władzom carskim w szcze-

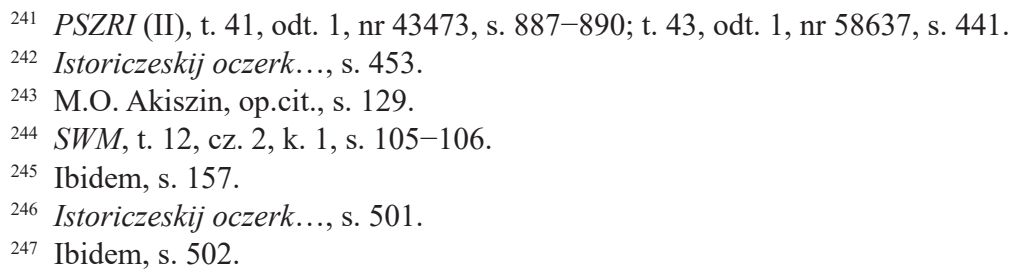


gólności doskwierał brak audytorów znających język polski, co utrudniało prace komisji sądowych i śledczych, zobowiązanych do możliwie najszybszego finalizowania prowadzonych spraw ${ }^{248}$. Od 1865 r. w związku z ostateczną likwidacją punktów polskiego oporu wskaźniki etatowe i rzeczywiste służb audytorskich zaczęły nieco spadać, ale w związku z rozpoczęciem prac nad reformą sądownictwa wojskowego, już od następnego roku, ponownie zaczęły wzrastać ${ }^{24}$. Faktycznie czynnikom rządowym nigdy nie udało się rozwiązać problemu niedoborów kadrowych w audytoriatach wojskowych. Skąpe zarobki, niski status służbowy, kiepskie warunki bytowe oraz pogardliwy stosunek społeczności oficerskiej do profesji audytora zawsze odpychały od niej młodych i zdolnych adeptów sztuki wojennej.

\section{SYLWETKI ZWIERZCHNIKÓW CENTRALNYCH I POLOWYCH ORGANÓW AUDYTORSKICH}

Za pierwszego rosyjskiego generała audytora historycy zgodnie uznają Iwana Kikina (1660-1723). Początek jego służby na dworze carskim w charakterze stolnika datuje się na schyłek XVII w. Pomiędzy 1696 r. a 1699 r. piastował funkcję wojewody w Ustjugu Wielkim. Po raz pierwszy z wojskowym wymiarem sprawiedliwości Kikin zetknął się w 1707 r., kiedy został audytorem w Lejb-Gwardii Pułku Prieobrażenskim, w następnym roku uczestnicząc także w pracach kilku kriegsrechtów powoływanych przez Piotra I. Godność tę piastował do $1711 \mathrm{r}$., sprawując równolegle urząd pomocnika generałkriegskomisarza. Rok 1712 przyniósł Kikinowi awans na generała audytora przy kancelarii wojskowej, z tym że dodatkowo sprawował on zarząd nad sprawami polowymi $\mathrm{i}$ - zapewne $\mathrm{z}$ racji zdobytych już doświadczeń - gospodarczymi armii. Zatem od samego początku pion sądowy posiadał ścisłe związki z innymi działami funkcjonowania sił zbrojnych, w tym głównie z intendenturą. Ponieważ Kikin sprawował pieczę nad skarbem carewicza Aleksieja, został w 1718 r. aresztowany w związku z oskarżeniem swego patrona o zdradę państwa. Uniewinniony co prawda po przeprowadzeniu śledztwa, stracił jednak zaufanie cara i został odesłany do Astrachania ${ }^{250}$.

Od 1714 r. funkcję generała audytora pełnił F. Glebow (1673- po 1726). Służbę rozpoczął w 1689 r. w stopniu porucznika gwardii w Pułku Prieobrażenskim, uczestnicząc w kampaniach Wojny Północnej. Na mocy rozkazu Piotra I odkomenderowano go w 1709 r. do armii dowodzonej przez generała feldmarszałka Borysa Szeremietjewa. W okresie 1715-1719 Glebow był obersternkriegskomi-

\footnotetext{
${ }^{248}$ APR, ZNWOR, sygn. 34, s. 99-100.

${ }^{249}$ Istoriczeskij oczerk..., s. 502.

${ }^{250}$ M.O. Akiszin, op.cit., s. 121, 123.
} 
sarzem, czyli odpowiadał za sprawy zaopatrzeniowe jednostek. Zajmując już stanowisko oberaudytora, odegrał ważną rolę w podpisaniu umowy kapitulacyjnej, jaką Szeremietjew podpisał ze szwedzkim generał-gubernatorem Rygi w $1710 \mathrm{r}$. w sprawie poddania twierdzy Rosjanom. Po uzyskaniu promocji na generała audytora w 1714 r., Glebow wchodził w skład komisji zajmującej się delimitacją granicy rosyjsko-tureckiej po pokoju pruckim ${ }^{251}$.

Od 1719 r. do 1752 r. stanowisko generała audytora lejtnanta, a następnie generała audytora przy Kolegium Wojny zajmował F. Centarow (lub Centarowi), prawdopodobnie Czech z pochodzenia. Uczestniczył on między innymi w pracach komisji ustanowionej do przeglądu regulaminów wojskowych, podobnie jak niejaki Miekutorow, w 1721 r. piastujący funkcję generał-audytora lejtnanta przy Kolegium Wojny. Centarow znany był między innymi z tego, że zaproponował kształcenie audytorów rosyjskich również w zakresie znajomości obcych regulaminów wojskowych ${ }^{252}$.

Operujące w polu armie posiadały własnych urzędników sądowych, używających różnych tytułów. W 1702 r. generał Szeremietjew nominował na audytora swych wojsk S. Chruszczowa, zaś przy siłach zbrojnych podlegających generałowi Aleksandrowi Mienszykowowi generałem audytorem lejtnantem był w $1709 \mathrm{r}$. niejaki Matezius ${ }^{253}$. Więcej można powiedzieć na temat Josefa de Creutza, jednego z prawników wojskowych, jakich udało się agentom carskim sprowadzić z zagranicy. Po przybyciu do Rosji w 1711 r. zasugerował on podjęcie działań na rzecz unowocześnienia struktur audytorskich poprzez wyznaczenie do pomocy oberaudytorom pisarza i dwóch dragonów, jak również zaprowadzenie ścisłej łączności pomiędzy nimi a policją wojskową, czego wymagały ówczesne procedury sądowe oparte na zasadach procesu inkwizycyjnego. Pomiędzy $1715 \mathrm{r}$. a 1719 r. Creutz był generałem audytorem lejtnantem, a potem generałem audytorem przy formacjach wojskowych kwaterujących w Polsce. Odesłany do Sankt Petersburga, stanął w 1719 r. przed sądem za zbrodnię maruderstwa, jakiej dopuścił się w stosunku do polskiej ludności cywilnej, zatajenie ważnej korespondencji o charakterze politycznym, jak i nieprzyzwoitych wypowiedzi na temat Piotra I oraz metodach sprawowania przez niego władzy. Skazany na śmierć przez ścięcie, Creutz musiał zostać ułaskawiony, ponieważ w 1725 r. przebywał pod ścisłą kontrolą w Twierdzy Szliselburskiej ${ }^{254}$. Wiadomo, że po przymusowym wyjeździe Creutza oberaudytorem przy wojskach rosyjskich stacjonujących w Gdań-

${ }^{251}$ Ibidem, s. 123-124.

252 M.P. Roziengiejm, op.cit., s. 174-175; L.G. Bieskrownyj, Russkaja armija i ftot $w$ XVIII wiekie (Oczerki), Moskwa 1958, s. 132; SWM, t. 12, cz. 1, k. 1, s. 194.

${ }^{253}$ Pis'ma i bumagi Pietra Wielikogo, Sankt-Pietierburg 1889, s. 16-17; M.P. Roziengiejm, op.cit., s. 173.

${ }^{254}$ M.O. Akiszin, op.cit., s. 124-125. 
sku został w 1716 r. Niemiec nazwiskiem Ertman, który prowadził negocjacje z członkami magistratu miejskiego odnośnie wspólnych operacji przeciwko flocie szwedzkiej ${ }^{255}$. Niektórzy autorzy wspominają także o oberaudytorze pochodzenia duńskiego, prawniku Ernście Fridrichu Crompeinie (bądź Krompeinie), działającym przy jednostkach stacjonujących na ziemiach polskich na początku drugiego dziesięciolecia XVIII w. Miał on opracować pierwszą wersję Krótkiego ujęcia procesów lub spraw sądowych. Przeniesiony w $1721 \mathrm{r}$. do służby cywilnej, jako pracownik Kolegium Sprawiedliwości, pracował nad projektem kodyfikacji prawodawstwa rosyjskiego ${ }^{256}$.

Po utworzeniu Audytoriatu Generalnego jego pracami od 1797 r. do 1811 r. kierowało dwóch generałów audytorów, a po jego reaktywacji w 1836 r., aż do 1867 r. - trzech. Natomiast na czele departamentu audytorskiego w latach 1812-1836 stało pięciu generał-audytorów. Ich personalia wraz z datami urzędowania zostały przedstawione $\mathrm{w}$ tabeli 1 .

Tabela 1. Generałowie audytorzy armii rosyjskiej w okresie 1797-1867

\begin{tabular}{|l|l|}
\hline Okres urzędowania & Generałowie audytorzy \\
\hline $1797-1800$ & Iwan Szachowskij \\
\hline $1801-1811$ & Siemion Sałagow (Sołogaszwili) \\
\hline $03.12 .1812-03.09 .1816$ & Siemion Panow \\
\hline $04.05 .1816-08.03 .1822$ & I. S. Bułyczew \\
\hline $08.04 .1822-06.03 .1824$ & S. K. Paszczenko \\
\hline $06.04 .1824-02.22 .1830$ & Iwan Miłowanow \\
\hline $02.23 .1830-03.22 .1853$ & Adam Noinskij \\
\hline $03.25 .1853-09.17 .1856$ & Iwan Jakobson \\
\hline $09.18 .1856-03.30 .1867$ & Wladimir Fiłosofow \\
\hline
\end{tabular}

Źródło: Wysszije i central'nyje..., s. 54, 211.

Poczet głównych zwierzchników resortu audytorskiego otwiera książę Iwan Szachowskij (1740-1811). Karierę wojskową rozpoczął w 1751 r. Od 1762 r. rotmistrz Lądowego Szlacheckiego Korpusu Kadetów, awansowany do stopnia podpułkownika trzy lata później. Po promocji służył w pułku kirasjerów, a potem już w randze pułkownika walczył przeciwko konfederatom barskim w szeregach

255 Ibidem, s. 125.

256 D.O. Sierow, Iz istorii wojennogo zakonodatiel'stwa Rossii XVIII wieka: „, Kratkoje izobrażenije processow ili sudiebnych tjażeb" (razyskanija o wnieszniej istorii tieksta) [w:] Wojna i orużije. Nowyje issliedowanija i matieriały: Trudy mieżdynarodnoj nauczno-prakticzeskoj konfieriencii, cz. 3, Sankt-Pietierburg 2012, s. 181. 
Wiackiego Pułku Karabinierów. Promowany na generała majora w 1775 r. był członkiem Kolegium Wojny. W okresie 1800-1811 Szachowskij został wyniesiony do rangi rzeczywistego tajnego radcy i godności senatorskiej ${ }^{257}$.

Siemion Sałagow (1756-1820) wywodził się ze starego rodu ormiańskiego, który od XIV w. uzyskał tytuł książęcy. W następnych latach ci jego przedstawiciele, którzy przeszli na prawosławie obrządku gruzińskiego używali również nazwiska Sołogaszwili. Sałagow rozpoczął służbę wojskową w 1771 r. jako podchorąży w Siewskim Pułku Piechoty. Pięć lat później przeniesiono go do lekkokonnego Pułku Czernihowskiego sformowanego z kozaków. Od 1778 r. kwatermistrz pułkowy, awansowany w 1784 r. na podporucznika. Od 1789 r. przebywał przy głównodowodzącym Armii Kaukaskiej, wypełniając tajne rozkazy i uczestnicząc w rokowaniach z plemionami górskimi. Po promocji do stopnia generał majora w 1797 r. Sałagow został najpierw dowódcą Smoleńskiego Pułku Dragonów, a potem lejb-gwardii pułku huzarów. Generał lejtnant od 1800 r. z jednoczesną nominacją na senatora. Wrzesień 1805 r. przyniósł desygnowanie Sałagowa na przewodniczącego Audytoriatu Generalnego, a po jego likwidacji na początku 1812 r. - na stałego członka rady przy ministrze wojny. Sałagow uczestniczył w dwóch wojnach tureckich z lat 1768-1774 i 1787-1792, zaś wyróżniwszy się podczas oblężenia Chocimia otrzymał awans na podpułkownika. W walkach ze Szwecją (1788-1792) zajmował się organizowaniem dostaw dla armii, natomiast w dobie zmagań z siłami napoleońskimi stał na czele Komitetu Organizacyjnego petersburskiego pospolitego ruszenia ${ }^{258}$.

Następca Sałagowa na urzędzie generała audytora w departamencie audytorskim generał major Siemion Panow (1757-1844) przez dziesięć lat służył w Korpusie Inżynieryjnym i sztabie generał-feldcechmajstra. W 1812 r. został członkiem dwu komisji funkcjonujących przy Audytoriacie Polowym Armii Czynnej. Zadanie pierwszej koncentrowało się wokół doprowadzenia do końca nierozstrzygniętych w resorcie wojny spraw, a drugiej - wyjaśnienia okoliczności zabójstwa jednego z chanów Mniejszej Ordy kirgisko-kasjackiej. Promocję na generała majora uzyskał w $1801 \mathrm{r}^{259}$.

${ }^{257}$ Russkaja impieratorskaja armija (strona poświęcona rosyjskiej armii cesarskiej i wchodzących w jej skład formacji wojskowych), http://regiment.ru/bio/SH/169.htm [dostęp: 23.03.2018].

${ }^{258}$ S.W. Wołkow, Gienieralitiet Rossijskoj impierii. Encikłopiediczeskij słowar' gienierałow $i$ admirałow ot Pietra I do Nikołaja II, t. 2, Moskwa 2009, s. 448.

259 Russkij Biograficzeskij Stowar' (dalej: RBS), t. 13, Sankt-Pietierburg 1902, s. 265-266; Gienieralitiet rossijskoj impieratorskoj armii i fłota (strona z biogramami generałów armii i floty carskiej), http://www.rusgeneral.ru/general_p.html [dostęp: 21.03.2018]; O.W. Grigor'jew, Gienierat-auditory $w$ sudiebnoj sistiemie Rossijskoj Impierii $w$ XIX w., „Uczenyje zapiski Orłowskogo gosudarstwiennogo uniwiersitieta" 2014, nr 2 (58), s. 247. 
Iwan Miłowanow (1764-1837) był synem popa. Po ukończeniu szkoły (nie wiadomo jakiej) rozpoczął w 1783 r. służbę cywilną w guberni tulskiej. Rok 1785 r. przyniósł mu nadanie rangi registratora kolegialnego. Następnie pracował jako sekretarz Nowosilskiego Sądu Powiatowego, a w 1790 r. przeszedł z resortu cywilnego do armii, na stanowisko oberaudytora. Promowany do stopnia majora w 1793 r., po trzech latach dosłużył się szlifów podpułkownika. Cztery lata Miłowanow służył w Małorosyjskim Pułku Grenadierów. Od 1797 r. został zatrudniony w Kolegium Wojny sprawując funkcję obersekretarza, z jednoczesnym awansem na radcę dworu, a potem - jeszcze tego samego roku za zasługi służbowe - na radcę kolegialnego. Rok 1802 przyniósł mu członkostwo w Kolegium Wojny i promocję na generała majora. Zajmując to stanowisko, brał udział w pracach pionu komisarskiego oraz organu powołanego do załatwienia nierozstrzygniętych spraw resortu wojny, jak również przeprowadzał przegląd formacji dragonów kwaterujących wzdłuż linii kaukaskiej. Pomiędzy 1812 r. a 1826 r. był stałym członkiem rady ministra wojny, piastując równolegle urząd generała audytora i dyrektora departamentu audytorskiego. W 1824 r. Miłowanow został wyniesiony do trzeciej rangi urzędniczej w lądowych siłach zbrojnych, co oznaczało jego przeniesienie z linii do kategorii urzędników wojskowych. Po odejściu z departamentu audytorskiego w 1830 r. otrzymał godność senatorską, z oddelegowaniem do 2 wydziału 6 moskiewskiego Departamentu Senatu ${ }^{260}$.

Po Miłowanowie nastały w departamencie audytorskim rządy Adama Noinskiego (1785-1853). Urodził się w rodzinie szlacheckiej. W 1795 r. rozpoczął pracę w Mohylewskim Konsystorzu rzymsko-katolickim w charakterze podkancelisty. Pomiędzy 1798 r. a 1799 awansował na kancelistę, a potem starszego sekretarza, z jednoczesnym przeniesieniem do rzymsko-katolickiego departamentu Kolegium Sprawiedliwości, gdzie uzyskał rangę registratora kolegialnego. W latach 1802-1804 Noinskij pełnił służbę w Komitecie do spraw zbadania skarg, jakie wpłynęły do Senatu, zaś po jego rozwiązaniu w tymczasowym departamencie apelacyjnym Senatu. Uzyskawszy tam nominację na sekretarza gubernialnego, przeszedł w 1805 r., po likwidacji tymczasowych departamentów Senatu, do Ministerstwa Sprawiedliwości na urząd tłumacza w Komitecie opracowywania praw. Od 1807 r. Noinskij przebywał najpierw przy osobie tajnego radcy Ignatija Tiejlsa, odpowiedzialnego za proces integracji okręgu białostockiego z obszarami Cesarstwa Rosyjskiego, a potem pomagał w Brześciu Litewskim prowadzić śledztwo w sprawie nielegalnego przerzutu zabronionych towarów przez granicę. Od 1806 r. radca tytularny. Dwa lata później nominowany na zastępcę naczelnika referatu w pierwszej ekspedycji jednego z departamentów Ministerstwa Sprawiedliwości. W 1810 r. awansowany na asesora kolegialnego, dzięki czemu od

${ }^{260}$ S.W. Wołkow, Gienieralitiet Rossijskoj..., s. 148; O.W. Grigor'jew, op.cit., s. 247. 
1812 r. mógł pełnić funkcję prokuratora w guberni woroneskiej. Za sumienną pracę Noinskij został w $1815 \mathrm{r}$. radcą dworu, z odkomenderowaniem do kancelarii generała dyżurnego w Sztabie Jego Cesarskiej Wysokości. Tym samym rozpoczął on służbę wojskową. Już w 1816 r. wyznaczony na zarządcę rzeczonej kancelarii. Pomiędzy 1824 r. a 1826 r. dwukrotnie promowany do piątej i czwartej rangi w hierarchii urzędników wojskowych. Po odesłaniu części kancelarii szefa Sztabu Głównego na front turecki w 1828 r., Noinskij zawiadywał tą jej częścią, która pozostała w stolicy, pełniąc dodatkowo powinności szefa kancelarii generała dyżurnego. W 1829 r. zajmował urząd dyrektora kancelarii Ministerstwa Wojny, zostając członkiem Rady Wojennej i przewodniczącym Komisji Budowlanej przy ministrze wojny. Od 1830 r. generał audytor Sztabu Głównego. Siedem lat później promowany na tajnego radcę 261 .

Noinskiego zastąpił Iwan Jakobson (ok. 1800-1874). Urodzony w Danii, przyjechał do Sankt Petersburga w 1814 r. i wstąpił na służbę do Komisji Komisarycznej w charakterze pisarza nieetatowego. Po dwóch latach trafił do kancelarii ministra wojny już jako pracownik etatowy. W międzyczasie ukończył Uniwersytet Petersburski. Podczas wojny z Turcją (1828-1829) piastował godność sekretarza, zaś następnego roku naczelnika jednego z wydziałów Ministerstwa Wojny. Stanowisko to zajmował przez 12 lat. Uznawany za człowieka wykształconego i energicznego, Jakobson działał równocześnie jako członek Komitetu do przeglądu zbioru uchwał wojskowych, uczestnicząc także w pracach nad projektem nowej ustawy dotyczącej organizacji resortu wojny. Dodatkowo od $1841 \mathrm{r}$. pełnił funkcję urzędnika do zleceń specjalnych. Sprawował ją niedługo, po upływie roku podał się do dymisji. Niemniej w 1846 r. minister wojny zaproponował Jakobsonowi ponownie objęcie tej posady. Od $1851 \mathrm{r}$. był wicedyrektorem departamentu komisarycznego. Właśnie wtedy wyższe czynniki wojskowe dokonały negatywnej oceny funkcjonowania pionu sądowego armii. W rezultacie Jakobsona mianowano w 1853 r. na kierownika departamentu audytorskiego. Zarządzał nim cztery lata, po czym uzyskał nominację na generałkriegskomisarza. Po roku po raz kolejny zawitał do Ministerstwa Wojny jako członek Rady Wojennej z prawem głosu, będąc oprócz tego przewodniczącym Komisji do zbadania stanu departamentu komisarycznego. Następnie pracował w Komisji do oceny działalności departamentu prowiantowego. Koniec końców, w 1861 r. Jakobsona po raz

${ }^{261}$ SWM: Pamjat'o czlienach Wojenngogo Sowieta. Portriety i biograficzeskije oczerki, t. 3, otd. IV, pod ried. N.M. Zatworickogo, Sankt-Pietierburg 1907; s. 104-105; Ukazatiel' biograficzeskich swiedienij, archiwnych i litieraturnych matieriałow kasajuszczichsja czinow obszczego sostawa po Kancieljarii Wojennogo Ministierstwa z 1802 do 1802 g. wkljuczitiel'no, t. 3, otd. 5, s. $129-130$. 
drugi wyznaczono do Rady Wojennej oraz zawiadywania departamentem komisarycznym. Skończył służbę w randze rzeczywistego radcy stanu ${ }^{262}$.

Ostatnim szefem Audytoriatu Generalnego był Władimir Fiłosofow (1820-1894). Miał korzenie szlacheckie. Dzieciństwo spędził we wsi Bogdanowskoje, w powiecie noworżewskim guberni pskowskiej. W 1831 r. przyjechał do Sankt Petersburga, gdzie pobierał nauki dokształcające z zakresu łaciny, matematyki, historii, geografii i literatury. Od 1835 r. uczeń Cesarskiej Szkoły Nauk Prawnych, którą ukończył w 1841 r. otrzymując rangę radcy tytularnego. W tym samym roku rozpoczął pracę w kancelarii 2 departamentu Senatu, awansując w 1844 r. na asesora kolegialnego. Pomiędzy 1844 r. a 1850 r. Fiłosofow pełnił służbę w departamencie resortu sprawiedliwości, uzyskując w 1847 r. promocję na radcę dworu, zaś rok później na radcę kolegialnego. Na lata 1850-1854 przypadała jego praca jako oberprokuratora w różnych departamentach Senatu. Dodatkowo w okresie 1851-1856 piastował godność heraldmistrza. O wysokiej pozycji służbowej Fiłosofowa i uznaniu jego zasług świadczy fakt, że podczas uroczystości pogrzebowych Mikołaja I sprawował obowiązki mistrza ceremonii, natomiast w czasie koronacji Aleksandra II był heroldem. Po awansie na rzeczywistego radcę stanu uzyskał w 1856 r. nominację na generała audytora. W 1865 r. uzyskał, za wzorową służbę, rangę tajnego radcy, stając się rok później honorowym sędzią pokoju w powiatach pskowskim i noworżewskim guberni pskowskiej. Po rozwiązaniu Audytoriatu Generalnego w 1867 r. Fiłosofow został naczelnikiem Głównego Zarządu Sądowego w Ministerstwie Wojny (początkowo z zachowaniem tytułu generała audytora, zastąpionego później godnością sekretarza stanu) oraz pierwszym rosyjskim Głównym Prokuratorem wojskowym. W latach 60 . i 70. XIX w. działał w wielu komitetach zajmujących się całościową reformą sądownictwa armijnego, uczestnicząc również w uruchamianiu wojskowych sądów okręgowych w Charkowie, Odessie, Kazaniu, Warszawie i Orenburgu. Za jego szczególną zasługę uznaje się stworzenie od podstaw systemu nadzoru prokuratorskiego w carskich siłach zbrojnych. Za sumienną służbę Fiłosofowa nagrodzono w 1869 r. majoratem w Królestwie Polskim, który przynosił właścicielowi roczny dochód w wysokości 1500 rubli. Od 1878 r. honorowy sędzia pokoju okręgu sądowego i okręgu sądu pokoju. Rok 1881 przyniósł Fiłosofowi mianowanie na rzeczywistego tajnego radcę i członka Rady Państwa ${ }^{263}$.

${ }^{262} R B S$, t. 25, s. 60-62.

${ }^{263}$ Postużnoj spisok Czliena Gosudarstwiennogo Sowieta, stats-siekrietarja, diejstwitiel'nogo statskogo sowietnika Fitosofowa. Sostawlien 15 sientjabrja 1881 goda, http://bezmuzei.ucoz.ru/ publ/filosofovy/predstaviteli_roda_filosofovykh/posluzhnoj_spisok_filosofova_vd/7-1-0-16, [dostęp: 22.03.2018]. 
Analizę przebiegu karier przełożonych najwyższych organów audytorskich w XIX w. przeprowadził O. Grigoriew, choć nie zamieścił ich biogramów ${ }^{264}$. Ze względu na przyjęty odcinek czasowy autor ten, co jest zrozumiałe, pominął Szachowskiego, ale - co może dziwić - nie uwzględnił S. Paszczenki, zajmującego stanowisko generała audytora w latach $1822-1824$. Faktem jest, że o tym ostatnim trudno znaleźć informacje w dostępnych opracowaniach biograficznych. Podobnie sprawa ma się z I. Bułyczewem, który jednak został wzięty pod uwagę przez Grigoriewa, choć jego droga służbowa nie została opisana w niniejszej publikacji. $\mathrm{Z}$ grona wszystkich dziewięciu generałów audytorów tylko jeden - D. Fiłosofow posiadał wykształcenie prawnicze, będąc absolwentem Cesarskiej Szkoły Prawoznawstwa. Jego poprzednik Jakobson pobierał nauki na Uniwersytecie Petersburskim, ale nie wiadomo, na jakim wydziale. Wszyscy pozostali, z wyjątkiem Miłowanowa uczącego się w Szkole Duchownej w Tule, nie uzyskali żadnego wykształcenia szkolnego czy akademickiego ${ }^{265}$. Dlatego w swej profesji generałowie audytorzy musieli opierać się w pierwszym rzędzie na doświadczeniach zdobytych podczas pracy w organach wymiaru sprawiedliwości, co dawało możliwość zapoznania się z prawodawstwem tak na płaszczyźnie teoretycznej, jak i praktycznej. Na pewno sporą wiedzą oraz umiejętnościami, stanowiącymi pochodną służby w cywilnych instytucjach sądowych, prokuratorskich i administracyjnych, mogli się poszczycić: Fiłosofow, Noinskij, jak również Iwan Bułyczew. Ten ostatni przez 18 lat pełnił funkcję: urzędnika sądowego (strjapczij) w sądzie wyższej instancji do spraw chłopów państwowych i tzw. odnodworcow w Permie, asesora w tobolskiej Izbie Spraw Cywilnych, prokuratora tobolskiego magistratu gubernialnego i oberprokuratora tymczasowego departamentu pomiarowego Senatu, pełniąc także przez dziesięć lat służbę w Czernihowskim Pułku Grenadierów. Mniejszą wprawę mieli Sałagow i Miłowanow, ale również oni przez kilka lat byli oberaudytorami. Panow otarł się z kolei o Audytoriat Polowy ${ }^{266}$.

Oprócz fachowej wiedzy i umiejętności z dziedziny nauk prawnych istotne znaczenie w zawodzie audytora najwyższego szczebla miały doświadczenia natury polowej. Dzięki nim urzędnik ten posiadał pojęcie o specyfice służby wojskowej, w tym przede wszystkim o regulaminach odnoszących się do rozmaitych pionów funkcjonowania armii. Obycie liniowe posiadali: Szachowskij, Sałagow, Panow, Bułyczew i Miłowanow. Dwaj pierwsi brali ponadto udział w działaniach bojowych, bez czego - jak słusznie stwierdził Grigoriew - audytorowi trudno

\footnotetext{
${ }^{264}$ O.W. Grigor'jew, op.cit., s. 246-248.

${ }^{265}$ Ibidem, s. 247.

${ }^{266}$ Ibidem.
} 
byłoby rozstrzygać sprawy oskarżonych o dokonanie przestępstwa w warunkach bojowych $^{267}$.

Jeśli w Audytoriacie Generalnym i departamencie audytorskim Ministerstwa Wojny najwięcej do powiedzenia mieli generałowie audytorzy, to w polowych odpowiednikach tych organów sytuacja wyglądała zgoła inaczej. Ponieważ najdłużej funkcjonującą i posiadającą najszerszy zasięg oddziaływania terytorialnego instytucją tego rodzaju był Audytoriat 1. Armii, to warto skoncentrować się na jego składzie osobowym, ukazanym w poniższym zestawieniu.

Tabela 2. Skład osobowy Audytoriatu Polowego 1 Armii (Armii Czynnej) od lat 40. XIX w. do $1874 \mathrm{r}$.

\begin{tabular}{|c|c|}
\hline Okres urzędowania & Stanowisko \\
\hline \multicolumn{2}{|r|}{ Przewodniczący (prezes) } \\
\hline $1850-1853$ & Gen. lejtnant Michaił Kuris \\
\hline $1853-1861$ & Gen. lejtnant Antoni Karłowicz \\
\hline $1862-1863$ & Gen. lejtnant Ignacy Mazurkiewicz \\
\hline $1863-1874$ & Gen. lejtnant Eduard Hagman (Hageman) \\
\hline \multicolumn{2}{|r|}{ Czlonkowie } \\
\hline $1850-1859$ & $\begin{array}{l}\text { Gen, major Eliasz Mansurow } \\
\text { (w latach 1850-1851 jako pełniący obowiązki) }\end{array}$ \\
\hline $1850-1855$ & $\begin{array}{l}\text { Gen. major Wasilij Dokudowskij } \\
\text { (w latach } 1850,1852-1855 \text { jako pełniący obowiązki) }\end{array}$ \\
\hline $1850-1855$ & $\begin{array}{l}\text { Gen. major Piotr Lewickij-Leontjew } \\
\text { (w latach } 1850,1852-1855 \text { jako pełniący obowiązki) }\end{array}$ \\
\hline $1856-1857$ & Gen. lejtnant Pawieł Łazarjew-Staniszczew \\
\hline $1856-1859$ & $\begin{array}{l}\text { Gen. major Alieksandr Jołoszyn } \\
\text { (jako pełniący obowiązki) }\end{array}$ \\
\hline $1857-1861$ & Gen. lejtnant Ignati Mazurkiewicz \\
\hline $1860-1861$ & Gen. lejtnant Alieksandr Baggowut \\
\hline $1862-1874$ & Gen. major Piotr Korniłowicz \\
\hline $1863-1866$ & $\begin{array}{l}\text { Pułkownik Fedor Tuchołka } \\
\text { (od } 1865 \text { r. w charakterze członka) }\end{array}$ \\
\hline $1864-1866$ & Gen. major Lew Lewszyn 2-gi \\
\hline 1874 & Gen. major Nikołaj Griszin \\
\hline 1874 & Gen. major Wasilij Donudowskij \\
\hline 1874 & $\begin{array}{l}\text { Podpułkownik Iwan Frankie } \\
\text { (jako pełniący obowiązki) }\end{array}$ \\
\hline
\end{tabular}

267 Ibidem, s. 248. 


\begin{tabular}{|c|c|}
\hline \multicolumn{2}{|r|}{ Polowy general audytor } \\
\hline w 1843 & Grigorjew \\
\hline $\begin{array}{l}\text { co najmniej od } \\
1846-1861\end{array}$ & $\begin{array}{l}\text { Radca stanu Michaił Biełajew } \\
\text { (po } 1851 \text { r. rzeczywisty radca stanu) }\end{array}$ \\
\hline $1862-1866$ & Rzeczywisty radca stanu Nikołaj Połtoranow \\
\hline 1874 & Radca tajny Kapiton Afanasjew \\
\hline \multicolumn{2}{|r|}{ Oberaudytorzy - naczelnicy wydziałów } \\
\hline $1850-1856$ & $\begin{array}{l}\text { Radca dworu Anton Noniewicz } \\
\text { (od } 1853 \text { radca kolegialny) }\end{array}$ \\
\hline $1850-1866$ & $\begin{array}{l}\text { Asesor kolegialny Iwan Matrozow } \\
\text { (od } 1858 \text { r. radca dworu; od } 1860 \text { r. radca kolegialny; od } 1864 \text { r. jako } \\
\text { urzędnik nadetatowy) }\end{array}$ \\
\hline $1854-1861$ & $\begin{array}{l}\text { Radca tytularny Kiriłł Martynowicz Martynow } \\
\text { (od } 1853 \text { r. asesor kolegialny; od } 1854 \text { oberaudytor) }\end{array}$ \\
\hline $1856-1861$ & $\begin{array}{l}\text { Radca tytularny Ignacy Rydecki } \\
\text { (od } 1858 \text { r. asesor kolegialny) }\end{array}$ \\
\hline $1862-1866$ & $\begin{array}{l}\text { Sekretarz kolegialny Kapiton Afanasjew } \\
\text { (od } 1864 \text { r. radca honorowy) }\end{array}$ \\
\hline $1863-1866$ & $\begin{array}{l}\text { Radca honorowy Alieksandr Pawlinskij } \\
\text { (od } 1865 \text { r. asesor kolegialny) }\end{array}$ \\
\hline $1865-1866$ & Sekretarz kolegialny Kapiton Chupotski \\
\hline 1874 & Radca kolegialny Wasilij Afanasjew \\
\hline 1874 & Radca dworu Nikołaj Chutopskij \\
\hline \multicolumn{2}{|r|}{ Audytorzy - zastępcy naczelników wydziałów } \\
\hline $1850-1851$ & Radca tytularny Fedor Gorochow \\
\hline $1850-1855$ & Radca tytularny Konstanty Gierasimow \\
\hline $1850-1866$ & $\begin{array}{l}\text { Radca tytularny Michaił Łukjanow } \\
\text { (od } 1857 \text { r. asesor kolegialny; od } 1864 \text { r. jako urzędnik nadetatowy) }\end{array}$ \\
\hline $1850-1861$ & Radca tytularny Kiriłł Martynow \\
\hline $1850-1865$ & $\begin{array}{l}\text { Sekretarz kolegialny Jachim Szyrajew } \\
\text { (od } 1853 \text { radca tytularny; od } 1858 \text { r. asesor kolegialny; od } 1864 \text { r. jako } \\
\text { urzędnik nadetatowy) }\end{array}$ \\
\hline $1850-1855$ & $\begin{array}{l}\text { Sekretarz gubernialny Ignacy Rydecki } \\
\text { (od } 1853 \text { r. sekretarz kolegialny) }\end{array}$ \\
\hline $1852-1855$ & Registrator kolegialny Lieontij Iwanow \\
\hline $1855-1861$ & Sekretarz kolegialny Michaił Gonczarow \\
\hline $1856-1861$ & $\begin{array}{l}\text { Registrator kolegialny Iwan Smirnow } \\
\text { (od } 1857 \mathrm{r} \text {. sekretarz gubernialny) }\end{array}$ \\
\hline $1856-1874$ & $\begin{array}{l}\text { Registrator kolegialny Stiepan Capul } \\
\text { (od } 1857 \text { r. sekretarz gubernialny; od } 1860 \text { r. sekretarz kolegialny; od } \\
1863 \text { r. radca honorowy; asesor kolegialny) }\end{array}$ \\
\hline
\end{tabular}




\begin{tabular}{|l|l|}
\hline $1856-1874$ & $\begin{array}{l}\text { Registrator kolegialny Pawieł Riazanowskij } \\
\text { (od 1857 sekretarz gubernialny; od 1860 r. sekretarz kolegialny; od } \\
1863 \text { r. radca honorowy; od 1866 r. asesor kolegialny) }\end{array}$ \\
\hline $1857-1866$ & $\begin{array}{l}\text { Sekretarz gubernialny Eufem Strielbickij } \\
\text { (od 1859 sekretarz kolegialny; od 1862 r. radca honorowy; od 1864 r. } \\
\text { asesor kolegialny) }\end{array}$ \\
\hline $1858-1874$ & $\begin{array}{l}\text { Sekretarz gubernialny Alieksandr Pławtow } \\
\text { (od 1860 r. sekretarz kolegialny; od 1863 r. radca honorowy; od } \\
1866 \text { r. asesor kolegialny) }\end{array}$ \\
\hline 1874 & Radca tytularny Władimir Martynow \\
\hline \multicolumn{2}{|c|}{ Zarządzający sprawami sekretariatu Audytoriatu Polowego } \\
\hline $1850-1855$ & $\begin{array}{l}\text { Registrator kolegialny Michaił Gonczarow } \\
\text { (od 1853 r. sekretarz gubernialny) }\end{array}$ \\
\hline $1855-1866$ & $\begin{array}{l}\text { Registrator kolegialny Lieontij Iwanow } \\
\text { (od 1856 sekretarz gubernialny; od 1859 sekretarz kolegialny; od } \\
1862 \text { radca tytularny) }\end{array}$ \\
\hline 1874 & Asesor kolegialny Ałdjar Iwanow \\
\hline \multicolumn{2}{|c|}{ Tłumacze } \\
\hline $1852-1861$ & Asesor kolegialny Stanisław Milewski \\
\hline \multicolumn{3}{|l|}{ Odkomenderowani do Audytoriatu Polowego } \\
\hline 1855 & Radcy kolegialni: Pawieł Riazanowskij, Prokop Pawski \\
\hline 1874 & Radca tytularny audytor 2 batalionu saperów Michaił Pietrow \\
\hline
\end{tabular}

Źródło: Rocznik urzędowy obejmujący spis naczelnych władz Cesarstwa oraz wszystkich władz i urzędników Królestwa Polskiego na rok 1850, Warszawa 1850, s. 112-113; na rok 1851, Warszawa 1851, s. 122-123; na rok 1852, Warszawa 1852, s. 123; na rok 1853, Warszawa 1853, s. 121-125; na rok 1854, Warszawa 1854, s. 119-123; na rok 1855, Warszawa 1855, s. 119-121; na rok 1856, Warszawa 1856, s. 101; na rok 1857, Warszawa 1857, s. 91; na rok 1858, Warszawa 1858, s. 99-100; na rok 1859, Warszawa 1859, s. 99-101; na rok 1860, Warszawa 1860, s. 98; na rok 1861, Warszawa 1861, s. 103-105; Rocznik urzędowy Królestwa Polskiego na rok 1862, Warszawa 1862, s. 94-95; na rok 1863, Warszawa 1863, s. 91-92; na rok 1864, Warszawa 1864, s. 90-91; na rok 1865, Warszawa 1865, s. 91-93; na rok 1866, Warszawa 1866, s. 93-94; Pamjatnaja kniżka warszawskoj gubiernii na 1874 god, Warszawa 1874, s. 24-25; W.A. Dokudowskij, op.cit., s. 81, 100.

Polowi generałowie audytorzy w rangach urzędników cywilnych nie posiadali istotnego wpływu w procesie decyzyjnym, co wyraźnie dał do zrozumienia, przytaczany już powyżej generał major Dokudowski. Najwięcej do powiedzenia w procesie rewidowania spraw mieli prezesi. W latach $1850-1874$ było ich, co najmniej czterech. O pierwszym z nich Michaile Kurisie dostępne materiały nie przekazują w zasadzie żadnych informacji, nawet dat jego urodzin i śmierci. Wiadomo tylko, ze z 1827 r. otrzymał awans na generała majora, a dwadzieścia lat później na generała lejtnanta ${ }^{268}$. Jego zastępcą został Antoni Karłowicz (1785 - po

${ }^{268}$ Gienieralitiet rossijskoj impieratorskoj armii i flota (strona z biogramami generałów armii i floty carskiej), http://www.rusgeneral.ru/general_k8.html [dostęp: 25.03.2018]. 
1861). Po ukończeniu szkoły wojskowej w Wilnie rozpoczął służbę, jako chorąży, w 33 Pułku Jegrów, uczestnicząc w starciach z Turcją (1806-1812) oraz kampaniach wojny z Francją (1812-1815). Trzykrotnie ranny przebywał prawie trzy miesiące $w$ niewoli. Za odwagę wykazaną w boju awansowany na sztabskapitana. Od 1827 r. dowódca 4. Pułku Jegrów, w którego szeregach walczył przeciwko armii polskiej w 1831 r., między innymi w bitwach pod Grochowem i walkach o Warszawę. Po włączeniu 4. Pułku do Estlandzkiego Pułku Jegrów, stanął na jego czele. Rok 1835 przyniósł Karłowiczowi promocję do rangi generała majora, z wyznaczeniem kolejno na dowódcę: 2. Brygady 5. Dywizji Piechoty, 1. Brygady 6. Dywizji Piechoty oraz naczelnika 4. Dywizji Piechoty. Komenderując tą ostatnią formacją brał udział w pacyfikacji powstania węgierskiego w 1849 r. Desygnowany w 1853 r. na przewodniczącego Audytoriatu Polowego Armii Czynnej dzierżył ten urząd niemal przez dziewięć lat. W 1861 r. dosłużył się stopnia generała piechoty, z jednoczesnym przeniesieniem w stan spoczynku ${ }^{269}$.

Ignacy Mazurkiewicz (1794-1867) urodził się na Litwie w rodzinie szlacheckiej herbu Łabędź. Podczas wojny z Francją w 1812 r. trafil, jako oficer w randze junkra, do pułku ciężkiej kawalerii, w korpusie gwardii. Uczestniczył w operacjach z lat 1813-1814, dosłużywszy się stopnia sztabsrotmistrza. Po zakończeniu wojny w 1814 r. rozpoczął służbę w 1. Dywizji Kirasjerów, wchodzącej w skład korpusu gwardii w Sankt Petersburgu. Kariera Mazurkiewicza uległa przyśpieszeniu w związku z powstaniem dekabrystów. Zaznaczając swój udział w jego stłumieniu, znalazł się w grupie zaufanych oficerów nowego cara - Mikołaja I. Począwszy od 1826 r., już w stopniu majora, w szeregach 1. Dywizji Kirasjerów, zmagał się z Turkami i Persami (1826-1829). Od 1830 r., w stopniu pułkownika, uczestniczył w pacyfikacji powstania polskiego. W 1831 r. formował w Pawłowsku wzorcowy pułk kawalerii. Rok 1839 przyniósł Mazurkiewiczowi promocję do rangi generał majora. Walcząc przeciwko Węgrom w okresie 1848-1849 uzyskał awans na generał lejtnanta kawalerii. Zaznaczył również swój udział w wojnie krymskiej (1854-1855), dowodząc od 1855 r. 1. Dywizją Kirasjerów. W 1857 r. wyznaczony przez cesarza na członka Audytoriatu Polowego 1. Armii, został pięć lat później jego prezesem. Dodatkowo pomiędzy 1855 r. a 1867 r. Mazurkiewicz był senatorem z departamentu warszawskiego w Królestwie Polskim. Zapewne za zasługi otrzymał w posiadanie wieś Czersk ${ }^{270}$.

Funkcję ostatniego szefa Audytoriatu Polowego 1. Armii piastował Eduard Hagman (Hageman) (1807-1880). Uzyskał wykształcenie podstawowe w szko-

269 RBS, t. 8, s. 526.

270 Spisok gienierałam po starszinstwu, Sankt-Pietierburg 1859, s. 114; Sankt-Pietierburg 1862, s. 160-161; Sankt-Pietierburg 1867; s. 156; Russkaja impieratorskaja armija, http://regiment.ru/ bio/M/141.htm [dostęp: 19.03.2018]. 
le prywatnej, wstępując w 1824 r. do 3. Kompanii Artylerii Konnej lejb-gwardii, jako ogniomistrz. Trzy lata później awansowany na chorążego. Tłumiąc powstanie w Królestwie Polskim (1830-1831) uzyskał awans do rangi podporucznika. Pełniąc służbę w artylerii gwardyjskiej został już w 1838 r. pułkownikiem z nominacją na dowódcę 3. Baterii 2. Brygady Artylerii lejb-gwardii. W okresie 1842-1852 Hagman stał na czele 5. Brygady Artylerii. Promocję na generała majora uzyskał w 1847 r. Uczestniczył w starciach z powstańcami Lajosa Kossutha dwa lata później. Jako dowódca 3. Dywizji Artylerii (od 1852 r.) walczył na Półwyspie Krymskim w kampaniach lat 1854 i 1855. W 1856 r. Hagman awansował na generała lejtnanta, pełniąc od $1861 \mathrm{r}$. funkcję komendanta twierdzy nowogieorgijewskiej (modlińskiej). Ustępując po dwóch latach z tego stanowiska, stanął na czele Audytoriatu Polowego 1. Armii, którym kierował najdłużej ze wszystkich prezesów, bo prawie jedenaście lat. Od 1874 r. trafił do wojsk rezerwowych artylerii pieszej i chociaż nie pełnił już żadnych obowiązków służbowych, po upływie trzech lat mianowano go na generała artylerii. W 1869 r. Hagman został właścicielem majoratu w Królestwie Polskim, generującym roczny dochód w wysokości 1200 rubli $^{271}$.

Spośród trzech przewodniczących Audytoriatu Polowego 1. Armii, żaden nie posiadał specjalistycznego wykształcenia prawniczego, jakim mogli się szczycić niektórzy szefowie Audytoriatu Generalnego i departamentu audytorskiego. Notabene, wiedza fachowa z zakresu nauk prawnych wcale nie była im potrzebna, albowiem organ, któremu przewodzili, i tak całkowicie podlegał głównodowodzącemu wojsk rosyjskich w Królestwie Polskim. Ponadto teoretycznie został on przewidziany dla warunków wojennych. Z drugiej strony trzej ostatni prezesi w przeciwieństwie do niektórych zwierzchników instytucji audytorskich szczebla centralnego - mieli ogromne doświadczenie liniowe. Wspinając się po kolejnych szczeblach kariery zyskiwali coraz lepsze rozeznanie w zagadnieniach wojskowych, również tych odnoszących się do sądownictwa wojskowego. Karłowicz, Mazurkiewicz oraz Hagman mieli za sobą udział w licznych operacjach bojowych, dowodząc jednostkami od szczebla roty, aż po dywizję i brygadę. Wszyscy oni pacyfikowali powstanie listopadowe i w następnych latach służyli na obszarach Kongresówki, gdzie Mazurkiewicz oraz Hagman posiadali majątki ziemskie. Dwóch ostatnich udekorowano nawet Orderem Orła Białego. Zatem ich związki ze sprawami polskimi - patrząc na nie z optyki Sankt Petersburga - były dość znaczące.

${ }^{271}$ S.W. Wołkow, Gienieralitiet Rossijskoj..., t. 1, s. 148; Jeżegodnik russkoj armii za 1881 g., Sankt-Pietierburg 1881, s. 107. 


\section{WNIOSKI KOŃCOWE}

Służby audytorskie oficjalnie przetrwały w rosyjskich lądowych siłach zbrojnych do 15 maja 1867 r. Tego dnia został zatwierdzony Regulamin wojskowo-sądowy, którego projekt rozpatrywano podczas wspólnego zebrania członków Audytoriatów Generalnych armii i floty. Ponieważ wprowadzanie w życie przepisów tej regulacji wymagało czasu ze względu na konieczność odpowiedniego przygotowania personelu, a co za tym idzie asygnowania niezbędnych środków pieniężnych, to proces likwidacji audytoriatów także musiał postępować stopniowo. Najpierw w niektórych dywizjach odwołano oberaudytorów zalecając, aby na dwa pułki przypadało tylko po jednym takim urzędniku. Pierwszego września 1867 r. definitywnie wygasła działalność Audytoriatu Generalnego ${ }^{272}$. Jego miejsce zajął Główny Sąd Wojskowy. Na podstawie ukazu z 1 stycznia $1869 \mathrm{r}$. przejął on - jako najwyższa instancja kasacyjna - wszystkie sprawy prowadzone w lądowych siłach zbrojnych przez były Audytoriat Generalny. Nieco dłużej, bo do 1874 r., przetrwały Audytoriaty Polowe przy okręgach wojskowych warszawskim i kaukaskim. Ich likwidacja wiązała się z powoływaniem w skali całego Cesarstwa Rosyjskiego wojskowych sądów okręgowych działających w ramach okręgów wojskowych ${ }^{273}$. Co więcej, przez jakiś czas utrzymano stanowiska audytorów w formacjach wojsk lokalnych ${ }^{274}$. Pomiędzy 1862 r. a 1870 r. do Audytoriatu Generalnego, a potem Głównego Sądu Wojskowego napłynęło 4430 spraw, z czego do ostatecznego zatwierdzenia przez imperatora skierowano 1182 przypadki 275 .

Agendy audytorskie pojawiły się w Rosji na początku XVIII w., pierwotnie w charakterze pojedynczych urzędników instalowanych przy pułkach. Ponieważ, stosownie do intencji ustawodawcy powinni oni dysponować odpowiednią wiedzą prawniczą, to wyznaczono im rolę stróżów, czuwających nad prawidłowością stosowania ustaw przez sądy wojskowe, składające się z oficerów liniowych, w zdecydowanej większości nieobeznanych z tajnikami pracy organów sądowych. Audytorzy musieli również nadzorować przebieg śledztw, a potem procesów karnych, sprawując jednocześnie funkcję sekretarzy sądowych. Oprócz

27229 marca 1867 r. Senat polecił Ministerstwu Wojny utrzymać tymczasowo Audytoriat Generalny, aż do czasu wprowadzenia reformy sądownictwa w armii, zachowując jego dotychczasową nazwę i etat; zob. PSZRI (II), t. 42, otd. 1, nr 44412, s. 336.

${ }^{273}$ Obszerniejsze informacje na ten temat w: A.Ju. Biezugol'nyj, N.F. Kowaliewskij, W.Je. Kowaliew, Istorija wojenno-okrużnoj sistiemy w Rossii 1862-1918, Moskwa 2012.

${ }^{274}$ PSZRI (II), t. 44, odt. 1, nr 46610, s. 1; Istoriczeskij oczerk..., s. 481, 494. Zakres uprawnień Wyższego Sądu Wojskowego został szczegółowo sprecyzowany w: Ustaw wojenno-sudiebnyj (dopotnien pozdniejszimi uzakonienijami i rasporjażenijami po 1879 god) [w:] Swod wojennyj postanowlienij, t. 34, Sankt-Pietierburg 1879, s. 15-16, 177-188.

${ }^{275}$ Istoriczeskij oczerk..., s. 512. 
tego zarządzali taborem pułkowym, pomagając w czasie wojny kwatermistrzom w pełnieniu ich codziennych powinności. Do powyższych obowiązków, w różnych latach, dochodził jeszcze udział w procesie tworzenia prawa wojskowego oraz pertraktacjach prowadzonych w sprawie warunków kapitulacji twierdz, jak i ewidencjonowanie jeńców. Określenie rzeczywistej pozycji audytorów w działalności wojskowego wymiaru sprawiedliwości w Rosji do 1867 r. nie jest rzeczą prostą. Wymogi postawione im przez legislatora okazały się w warunkach rosyjskich trudne do spełnienia z powodu braku fachowych kadr jurystycznych. Dlatego wakaty audytorskie w pułkach zapełniali głównie piśmienni podoficerowie i pisarze, którzy doświadczenie zdobywali dopiero w toku codziennych zajęć. Zresztą zainteresowanych podjęciem tej profesji zawsze było niewielu, przede wszystkim z racji stosunkowo niewielkiego statusu służbowego audytorów, a co za tym idzie gorszych w porównaniu do służby w jednostkach liniowych możliwości uzyskania awansu. Wyższe stanowiska audytorskie zawsze piastowali oficerowie, ale poziom ich przygotowania zawodowego również często pozostawiał wiele do życzenia. Podlegając w kriegsrechtach oficerom asesorom, audytorzy zazwyczaj zajmowali się jedynie doborem odpowiedniego do potrzeb spraw materiału prawodawczego oraz wszelkiego rodzaju pracami kancelaryjnymi. O końcowym werdykcie decydowali sędziowie, niebędący zawodowymi prawnikami. Z drugiej strony zdarzały się przypadki, że pochłonięci obowiązkami natury polowej dowódcy, zarazem prezesi składów orzekających, przychylnie ustosunkowywali się do obiekcji proceduralnych audytorów, uzasadnionych przez nich w wyroku. Wówczas ci ostatni uzyskiwali realny wpływ na proces decyzyjny wojskowych instytucji wymiaru sprawiedliwości.

Przez większość XVIII w. armia rosyjska pozbawiona była centralnych organów sądowniczych. Dopiero w 1797 r. powołano, w osobie generała audytora dysponującego niewielkim personelem biurowym, tzw. Audytoriat Generalny. Uzyskał on prerogatywy najwyższej instancji sądowej dla lądowych sił zbrojnych i marynarki wojennej. Od 1805 r. Audytoriat Generalny funkcjonował już, jako ciało kolegialne, o statusie ministerstwa. Struktura ta została faktycznie zlikwidowana w 1812 r., a część jej obowiązków przejął departament audytorski, działający najpierw w ramach Ministerstwa Wojny, a potem Sztabu Głównego. Audytoriat Generalny przywrócono dopiero w 1832 r. Jego organem wykonawczym i przygotowawczym stał się wówczas departament audytorski. Główne zadanie Audytoriatu Generalnego, teraz nieco podobnego do Senatu, koncentrowało się wokół przeprowadzania rewizji wyroków kriegsrechtów, jakie zapadły w sprawach sądowych i śledczych. Niemniej zakres podległych mu spraw, w tym prawo do ostatecznego sankcjonowania orzeczeń końcowych, zmieniał się w kierunku pomniejszania jego uprawnień. Początkowo kompetencje Audytoriatu Generalnego obejmowały w praktyce wszystkie przypadki rozpatrywane w Ministerstwach Wojny i Marynarki Wojennej. 
Od 1832 r. zajmował się on już tylko sprawami podoficerów i szeregowców, w tym także tych wywodzących się ze szlachty, ale jeśli wyrok nie pozbawiał ich szlachectwa. Uszczuplenie prerogatyw wyższego sądu rewizyjnego wynikało z nadania po zakończeniu wojen napoleońskich wyższym dowódcom wojskowym ogromnych kompetencji sądowniczych w okresie pokoju Tym samym, generałowie feldmarszałkowie i generałowie stali się de facto wyższymi instancjami sądowymi. Niezależnie od powyższego faktu Audytoriat Generalny zawsze stanowił instancję niezależną od dowódców wojskowych, a nawet w okresie 1805-1812 od ministra wojny, dzięki czemu mógł do pewnego stopnia kontrolować i korygować poczynania głównodowodzących na niwie sądowej.

Podczas gdy Audytoriat Generalny i departament audytorski posiadały prawo do konfirmowania wyroków sądowych, tworzone od 1812 r. w ramach armii i samodzielnych korpusów audytoriaty polowe, formalnie przewidziane tylko dla stanu wojny, przeprowadzały jedynie audyty orzeczeń kriegsrechtów, a pełnia władzy w zakresie ich zatwierdzania należała do generałów feldmarszałków i generałów. Wyższe sądy rewizyjne działające przy związkach taktyczno-operacyjnych różniły się od swych odpowiedników funkcjonujących na szczeblu centralnym jeszcze tym, że w nadzwyczajnych wypadkach podlegały im sprawy cywilów uznanych przez władze rosyjskie za przestępców politycznych.

Instytucja audytoriatu zawsze była ściśle powiązana z procesem inkwizycyjnym i rewizyjnym trybem weryfikacji werdyktów sądów wojskowych. Dlatego kiedy wraz z reformą całego systemu wojskowego wymiaru sprawiedliwości w 1867 r. nastąpiło przejście, wzorem państw zachodnioeuropejskich, do rozpraw $\mathrm{z}$ udziałem stron i procedur opartych na zaskarżeniach orzeczeń sądowych w trybie kasacyjnym, instytucje audytorskie musiały zostać zlikwidowane. Audytorów zastąpili w armii sędziowie śledczy i prokuratorzy, w miejsce Audytoriatu Generalnego pojawił się Główny Sąd Wojskowy działający przy Ministerstwie Wojny, zaś audytoriaty polowe wyparł powoływany w razie konfliktu militarnego przy Sztabie Polowym Główny Sąd Polowy.

\author{
AUDIT SERVICES OF THE LAND ARMED FORCES \\ IN THE RUSSIAN COURT MARTIAL SYSTEM \\ BETWEEN THE 18TH CENTURY AND THE FIRST HALF \\ OF THE $19^{\text {TH }}$ CENTURY
}

\title{
Abstract
}

The consequence of the military reform conducted by Peter the Great was the creation of a regular army based on conscription. The introduction of modern armed forces resulted in the necessity of carrying out changes in the sphere of the court martial system. This process lasted until 1716 when Military Regulations were published. This document 
laid the foundations for the organization of the court martial system in the tsar army for many decades. Audit services became one of its elements. The purpose of this article is to acquaint readers with the overall organization as well as with the operating procedures of the audit institution until 1867. It was then liquidated due to the reform of the court martial carried out at the time. In order to facilitate understanding of the nature and specificity of this institution, a description of the court martial system in the Tsarist Russia between the $18^{\text {th }}$ and the $1^{\text {st }}$ half of the $19^{\text {th }}$ century is necessary.

\section{SERVICES D’AUDIT DES FORCES ARMEES TERRESTRES DANS LE SYSTEME DE JUSTICE MILITAIRE RUSSE

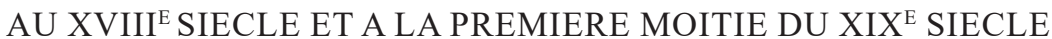

\section{Resumé}

L'un des conséquences de la réforme militaire réalisée en Russie par Pierre I ${ }^{\text {er }}$ a été la création d'une armée régulière. Le fonctionnement des forces armées modernes a provoqué les changements nécessaires du système de justice militaire. Ce processus a duré jusqu'à la publication du Règlement militaire en 1716. Ce document a constitué la base de l'organisation du système de justice dans l'armée tsariste pendant de nombreuses décennies. Les services d'audit en sont devenus la composante. L'objectif de notre étude est de présenter au lecteur polonais l'organisation générale et des principes de fonctionnement de l'institution de contrôle jusqu'en 1867 - la date à laquelle sa liquidation définitive a résulté de la réforme du système de la justice militaire qui à cette époque-là était en cours. Afin de mieux comprendre la nature et les spécificités de l'institution en question, il est nécessaire de caractériser la constitution du système de justice militaire en Russie tsariste dans l'intervalle de temps spécifié dans le titre. 